\title{
EQUITY EXTRATERRITORIALITY
}

\author{
S. NATHAN PARK*
}

\begin{abstract}
Territoriality is a foundational principle of international order, and U.S. laws have always operated on a territorial basis. However, when U.S. jurisprudence speaks of extraterritorial application of its laws, it is usually assessing whether the legislature or the court has jurisdiction over persons, properties and conducts outside of the territorial borders of the United States. This paper argues that such a conception of the extraterritoriality doctrine only reveals half of the picture, because U.S. courts may indirectly apply U.S. law beyond U.S. borders through extraterritorial court orders without relying on extraterritorial jurisdiction. I term such exercise of extraterritorial power "Equity Extraterritoriality," because the court's power to make such extraterritorial orders stems from the equity tradition.

Under Equity Extraterritoriality, U.S. courts first obtain jurisdiction over a person, then indirectly exercise extraterritorial authority by ordering the person to take certain actions outside of the courts' territorial jurisdiction, or dispose of properties located outside of the courts' territorial jurisdiction. Importantly, to Equity Extraterritoriality-which covers everything that happens in litigation other than jurisdiction, including provisional orders, discovery orders and post-judgment orders-there is hardly any application of territoriality principles, causing problems typically associated with extraterritoriality, such as causing a diplomatic strain. This contradicts U.S. law's general respect for territoriality, as well as the application of territoriality principles to limit judicial and legislative jurisdiction. This paper provides a brief overview of Equity
\end{abstract}

\footnotetext{
Copyright (C) 2017 S. Nathan Park

Career in Law Teaching Fellow, Columbia Law School; Adjunct Professor of Law, Georgetown Law Center; Of Counsel, Kobre \& Kim LLP. I am deeply grateful for generous and helpful comments from Pamela K. Bookman, Michelle Greenberg-Kobrin, Bert I. Haung, Olatunde Johnson, Gautam Kene, Ryan Liss, Henry P. Monaghan, Alex Raskolnikov, Carol Sanger, Peter L. Strauss, Ryan C. Williams and Taylor Washburn, as well as the associates and fellows at Columbia Law School. Special thanks to Michael S. Kim and Marcus J. Green of Kobre \& Kim LLP, whose creative use of Equity Extraterritoriality in their practice inspired the subject of this paper. This paper was selected to be presented at the New Voices in Conflict of Laws program at the 2017 annual meeting of the Association of American Law Schools. Many thanks to the Executive Committee of the AALS Section on Conflict of Laws-Patrick Borchers, Donald E. Childress III, Laura E. Little, Jamelle Sharpe and Christopher Whytock-for selecting the paper.
} 
Extraterritoriality's historical development, explores the problems posed by Equity Extraterritoriality's extraterritorial reach and under-development, and proposes a conflict-of-laws-based solution to apply territoriality principles so as to curb the worst excesses of Equity Extraterritoriality.

\section{TABLE OF CONTENTS}

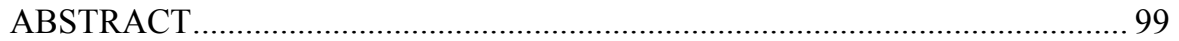

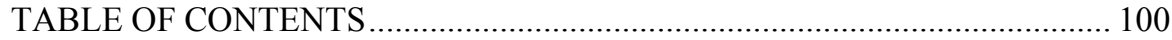

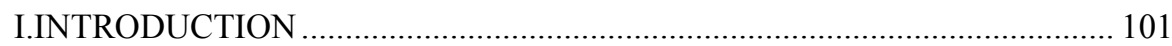

II.UNDERSTANDING EQUITY EXTRATERRITORIALITY ........................ 107

A. How Equity Extraterritoriality Governs Beyond Borders: a Case

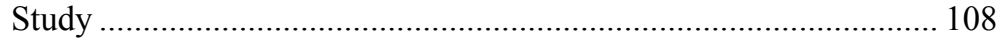

B. The Operation of Equity Extraterritoriality …................................ 112

III.HISTORY OF EQUITY EXTRATERRITORIALITY .................................. 113

A. Birth of Equity Extraterritoriality in Pennoyer v. Neff .................... 113

B. Growth of Equity Extraterritoriality in Early and Mid-20th

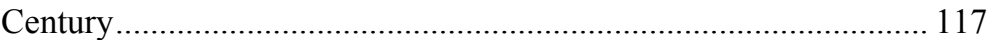

1. Equity Extraterritoriality in the Early 20th Century .................. 117

2. Two Growth Spurts: Merger of Law and Equity, and the Personal Jurisdiction Revolution ............................................................... 123

a. Merger of Law and Equity ............................................... 123

b. Personal Jurisdiction Revolution..................................... 125

C. Deepening Divide Between Common Law Extraterritoriality and

Equity Extraterritoriality in Late 20 $0^{\text {th }}$ Century ............................... 128

1. Jurisdictional Extraterritoriality Retrenches ............................. 129

2. Equity Extraterritoriality Grows in Neglect.............................. 131

D. Taking Stock of the U.S. Territoriality Doctrine Today................... 136

IV. PROBLEM OF EQUITY EXTRATERRITORIALITY .............................. 139

A. Measuring the Size of the Problem: the Case of Intangible

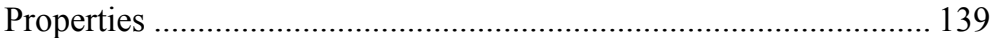

1. Rise of Intangible Properties.................................................... 140

2. Controlling Intangible Properties Through Equity Extraterritoriality

B. First Problem of Equity Extraterritoriality: Problem of Extraterritoriality

1. Interference with Foreign Sovereign Interest........................... 147

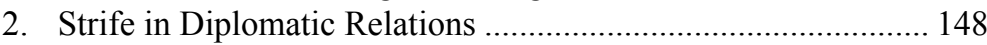

3. Creation of Conflicting Legal Obligations.................................. 150

C. Second Problem of Equity Extraterritoriality: Problem of Under-

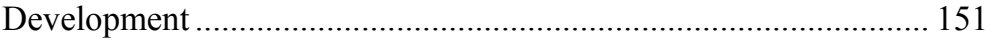

1. Practical Over-Extension of Equity Extraterritoriality.............. 152

2. Inconsistent Application of Territoriality ................................... 154

3. Fostering Inconsistency Within Jurisdictional Territoriality ..... 156 


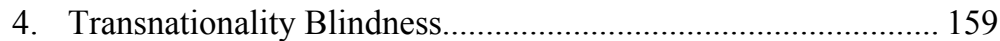

V. SOLVING THE PROBLEM OF EQUITY EXTRATERRITORIALITY ...... 162

A. Devising a Solution for Equity Extraterritoriality .......................... 162

1. Domestic Equity Extraterritoriality........................................... 164

2. International Equity Extraterritoriality........................................ 166

a. International Comity as the Animating Principle ............... 168

b. Proposed Approach: Comity-Fueled Conflict of Laws Test 170

c. Application of the Proposed Test....................................... 177

B. Potential Objections to the Proposed Test ............................... 179

VI. CONCLUSION

\section{INTRODUCTION}

CPLR [New York Civil Procedure Law and Rules] article 52 contains no express territorial limitation barring the entry of a turnover order that requires a garnishee to transfer money or property into New York from another state or country. It would have been an easy matter for the Legislature to have added such a restriction to the reach of article 52 and there is no basis for us to infer it from the broad language presently in the statute. $^{1}$

Territoriality is a foundational principle of the international order. Since the Peace of Westphalia of 1648, the world has been organized as multitudes of sovereign nations, each exercising exclusive governing authority over a defined territory. ${ }^{2}$ This understanding forms the basis of our current international law. The United States, having come to existence in 1776, has always operated its legal system on a territorial basis. ${ }^{3}$ A major expression of the territoriality principles in U.S. law is the presumption against extraterritorial application of U.S. laws, which has existed in U.S. jurisprudence for nearly as long as the Republic itself. ${ }^{4}$ While it is true that the relative strength of that presumption has waxed and waned throughout history, ${ }^{5}$ today, the doctrine of presumption against extraterritoriality is undergoing glory days. In a series of decisions during the last few decades, the Supreme Court repeatedly pronounced that as a general matter, U.S. laws

1. Koehler v. Bank of Berm. Ltd., 12 N.Y.3d 533, 539 (2009).

2. See Derek Croxton, The Peace of Westphalia of 1648 and the Origins of Sovereignty, 21 INT'L Hist. Rev. 569, 569-70 (1999); Kal RAustiala, Does the CONSTitution Follow the Flag?: ThE EVOLUTION OF TERRITORIALITY IN AMERICAN LAW 8 (1st ed. 2009).

3. See James Weinstein, Early American Origins of Territoriality and in Judicial Jurisdiction, 37 ST. Louis U. L. J. 1, 2-3 (1992).

4. See, e.g., Murray v. Schooner Charming Betsy, 6 U.S. (2 Cranch) 64, 118 (1804).

5. See discussion infra Sections III.B.2., III.C.1. 
apply only within the territorial borders of the United States. The holding in Morrison v. National Australian Bank, a 2010 case in which the Supreme Court decided that the implied cause of action created by Section 10(b) of the Securities Exchange Act of 1934 did not apply beyond U.S. borders, encapsulates the strength of territoriality principles in the U.S. law today: "unless a contrary intent appears" in the statute, the law "is meant to apply only within the territorial jurisdiction of the United States."

Given the strength of the presumption against extraterritoriality today, the above-quoted language from the recent case of Koehler v. Bank of Bermuda is surprising in its flagrant disregard of that presumption. In Koehler, the highest court of the State of New York found that Article 52 of the New York Civil Procedure Law and Rules ("CPLR") authorized a New York court to order the defendant to deliver certain stock certificates located in Bermuda. In so holding, the court first (correctly) noted that the text of CPLR Article 52 has no extraterritoriality limitation. And instead of eschewing extraterritorial application of Article 52, as the U.S. Supreme Court instructed in Morrison, the New York Court of Appeals took the opposite path and refused to "infer [a territorial limitation] from the broad language presently in the statute," reasoning that "[i]t would have been an easy matter for the Legislature to have added such a restriction to the reach of Article 52."7

The highest court of the United States says the law is to be applied within the territorial jurisdiction unless the law specifically states otherwise; the highest court of the State of New York says the law may be applied beyond the territorial jurisdiction, unless the law specifically states otherwise. How can these two seemingly contradictory propositions, issued just one year apart from each other, stand together? I suggest that the origin of this contradiction goes deeper than the superficial distinction between federal court and state court, or that between a substantive statute and a procedural statute. The contradiction originates from the fact that the New York Court of Appeals was applying a different tradition of the extraterritoriality doctrine in U.S. law, which developed on a track quite separate from that of the presumption against extraterritoriality.

This separate doctrine may be described as "Equity Extraterritoriality." A succinct definition of Equity Extraterritoriality may be "the court's authority, originating from the court's equitable powers, to order a person to take certain actions outside of the court's territorial jurisdiction." Equity

\footnotetext{
6. Morrison v. Nat'l Austl. Bank Ltd., 561 U.S. 247, 248 (2010).

7. Koehler v. Bank of Berm. Ltd., 911 N.E.2d 825, 829 (N.Y. 2009).
} 
Extraterritoriality is an indirect form of extraterritoriality. Rather than asserting jurisdiction directly over actions occurring beyond its territorial jurisdiction, the court (typically, but not always) first establishes its own jurisdiction over a person, then orders the person to take actions outside of the court's territorial jurisdiction. In this sense, Equity Extraterritoriality stands in opposition to "jurisdictional extraterritoriality," i.e. the court's authority to directly reach beyond its territorial jurisdiction.

Undoubtedly, Equity Extraterritoriality is an application of U.S. laws beyond the territorial boundaries of the United States. The fact that Equity Extraterritoriality reaches beyond U.S. borders indirectly through a person under the court's jurisdiction does not change the end result that a U.S. court is demanding compliance with its orders beyond its territorial jurisdiction. However, throughout its long history and to this day, U.S. territoriality doctrine has considered extraterritorial court orders as "territorial." This is so because the court usually establishes in personam jurisdiction over the person through which it is effectuating the extraterritorial order (although in practice, that is not always the case). ${ }^{8}$ Once the court obtains jurisdiction, the current U.S. territoriality doctrine considers everything occurring thereafter to be "territorial," notwithstanding the fact that extraterritorial court orders are no less an application of U.S. law beyond U.S. borders. In other words, the U.S. territoriality doctrine has focused almost exclusively on the question of "jurisdictionality," i.e. whether the court may assert judicial jurisdiction beyond its territorial jurisdiction. ${ }^{9}$ Once the jurisdictional hurdle is cleared, there is no meaningful application of territoriality principles to everything else that happens afterwards in litigation.

This means under Equity Extraterritoriality, the court may order the person under its jurisdiction to take a wide variety of extraterritorial actions, including: disposition of tangible and intangible property located outside of the court's territorial jurisdiction; ${ }^{10}$ preservation and delivery of evidence located outside of the court's territorial jurisdiction, ${ }^{11}$ discontinuation of a legal action filed in another country $;{ }^{12}$ prohibition of business transactions in

8. See discussion infra Sections II.A., IV.C.3.

9. See John H. Knox, A Presumption Against Extrajurisdictionality, 104 AM. J. INT'L L. 351, 352 (2010) (noting that much of "presumption against extraterritoriality" may be more properly described as "presumption against extrajurisdictionality").

10. See, e.g., Koehler, 911 N.E.2d at 829 .

11. See, e.g., Societe Nationale Industrielle Aerospatiale v. U.S. District Court, 482 U.S. 522, 522 (1987); Intel Corp. v. Advanced Micro Devices, Inc., 542 U.S. 241, 255 (2004).

12. See, e.g, Laker Airways Ltd. v. Sabena, Belgian World Airlines, 731 F.2d 909, 909 (D.C. Cir. 1984). 
another country, ${ }^{13}$ or nearly any other activity occurring entirely outside of the court's territorial jurisdiction. ${ }^{14}$ Yet there is essentially no legal test that limits this broad operation of Equity Extraterritoriality. The Supreme Court, which has been very active in the recent years in defining the contours of territoriality as applied to jurisdiction, has made virtually no attempt to address Equity Extraterritoriality. In some cases, the severe underdevelopment of Equity Extraterritoriality surprised even the Supreme Court itself. During the oral argument for Baker v. General Motors, a 1998 case involving Equity Extraterritoriality, Justice Stephen Breyer exclaimed with incredulity: "In 200 years of history, it must have come up before . . I'm amazed that there isn't something written [making this issue] absolutely clear." ${ }^{\text {"T }}$ The result of this under-development is the inconsistency in the U.S. territoriality doctrine that can be observed from the contradiction between Koehler and Morrison. Even as the Supreme Court admonished that U.S. laws must not be construed to apply beyond U.S. borders unless the law clearly authorized extraterritorial application, the New York Court of Appeals applied a New York law over the property located in Bermuda because the law did not clearly prohibit extraterritorial application. This inconsistency allows parties to achieve extraterritorial application of U.S. law that they generally cannot under the principles of territoriality.

The practical consequences of this inattention to Equity Extraterritoriality are significant. By reaching beyond their territorial jurisdiction via Equity Extraterritoriality, U.S. courts often contravene the interests of foreign sovereigns and cause diplomatic rows. ${ }^{16}$ The lack of meaningful check on Equity Extraterritoriality also allows U.S. courts to routinely put parties under conflicting legal obligations, holding them in terrorem to choose between disobeying a U.S. court order and breaking a foreign law. ${ }^{17}$ When the Second Circuit overextended the reach of Equity Extraterritoriality, its decision nearly destroyed banking in New York. ${ }^{18}$ These consequences will become more severe in the coming years as the role

13. See, e.g., NML Capital Ltd. v. Republic of Argentina, No. 08 Civ. 6978 (TPG), LEXIS 168292 at *9_*11 (S.D.N.Y. Nov. 21, 2012), aff'd 727 F.3d 230, 248 (2d Cir. 2013), cert. denied 134 S. Ct. 2819, 2819 (2014).

14. See Thomas Carl Spelling, Treatise on Injunctions and Other Extraordinary Remedies Covering Habeas Corpus, Mandamus, Prohibition, Quo Warranto, and Certiorari or Review 5 (2d ed. 1901) ("The range of purpose for which this remedial writ [an injunction] may be invoked is almost infinite.").

15. Transcript of Oral Argument at 18, Baker v. Gen. Motors Corp., 522 U.S. 222, 222 (1998) (No. 96-653).

16. See discussion infra Sections IV.B.1., IV.B.2.

17. See discussion infra Section IV.B.3.

18. See discussion infra Section IV.C.1. 
of Equity Extraterritoriality will only become more prominent in the future. A U.S. party engaged in global commerce has every incentive to try to control the activities occurring beyond U.S. borders by way of U.S. court adjudication. In addition, the ever-increasing importance of intangible properties - assets with no physical presence, except through the persons who control them-makes the indirect control of extraterritorial property through a person even more critical. ${ }^{19}$

Despite this urgency, scholarly attention to Equity Extraterritoriality has been scant. During the oral argument in Baker, Justice Anthony Kennedy inquired: "What I'm looking for is the case or the law review article in 200 years that went into what I would think was the most simple basic question[.]" ${ }^{, 20}$ If Justice Kennedy resumed the search for a law review article discussing the topic today, two full decades since Baker, he would be mostly disappointed. Although extraterritorial application of the U.S. law is a topic that inspires a great deal of legal scholarship, such scholarship almost exclusively focuses on jurisdictional extraterritoriality. ${ }^{21}$ To the extent they exist, studies of Equity Extraterritoriality are fragmented, as they do not treat it as a standalone inquiry. They either analyze the situation where Equity Extraterritoriality is incidentally connected to jurisdictional extraterritoriality (for example, when the court issues an extraterritorial injunction to apply the Sherman Antitrust Act abroad), ${ }^{22}$ or where a particular type of Equity Extraterritoriality happens to emerge as an issue in a discrete area of law (such as collection of evidence from abroad or protecting intellectual property across state borders). ${ }^{23}$ The most

19. See discussion infra Section IV.A.

20. Transcript of Oral Argument at 47, Baker v. Gen. Motors Corp., 522 U.S. 222, 222 (1998) (No. 96-653). See also Linda Greenhouse, Court Weighs Whether One State Must Obey Another's Courts, N.Y. TIMES, Oct. 16, 1997 at A25. As discussed further in this paper, the Baker opinion was a long way away from addressing the full array of problems associated with Equity Extraterritoriality because Baker only represented one genus of Equity Extraterritoriality. See discussion infra Section III.C.2.

21. A typical example is: RAUSTIALA, supra note 2, an excellent discussion of the history and current practice of extraterritorial application of the U.S. law that nonetheless focuses its attention almost entirely on the question of jurisdiction. Similarly, Justice Breyer's recent and highly acclaimed discussion of the extraterritorial applicability of U.S. law contains no meaningful analysis of extraterritorial court orders. See STEPHEN G. BREyer, The COURT AND THE World: AMERICAN LAW AND THE NEW GLOBAL REALITIES 112 (1st ed. 2015). This could also be due to the general lack of scholarly interest in the history of equity in the United States. See John R. Kroger, Supreme Court Equity, 1789-1835, and the History of American Judging, 34 Hous. L. REV. 1425, 1428 (1998) (noting the "extremely limited" knowledge about the history of U.S. Supreme Court equity).

22. See, e.g., Edward T. Swaine, The Local Law of Global Antitrust, 43 WM. \& MARY L. REV. 627, 641-42 (2001); Breyer, supra note 21 at 95-107.

23. See, e.g., Geoffrey Sant, Court-Ordered Law Breaking: U.S. Courts Increasingly Order the Violation of Foreign Law, 81 BROOKLYN L. REV. 181, 181-82 (2015) (collection of evidence); David S. 
comprehensive scholarly analysis of Equity Extraterritoriality, by Professor Polly Price, is nearly 20 years old (written partially in response to the Supreme Court's inquiry in Baker). ${ }^{24}$ While Price's article is highly insightful, it only considered half of the problem of Equity Extraterritoriality - namely, the domestic Equity Extraterritoriality situation in the context of U.S. federalism. There is virtually no scholarly discussion as to international Equity Extraterritoriality, in which no legal superstructure harmonizes the exercise of sovereignty by various nations.

This article attempts to fill this gap. Focusing only on jurisdictional extraterritoriality does not address the problems of Equity Extraterritoriality. To limit the excess of Equity Extraterritoriality, there must be a legal test that more forcefully applies the territoriality principles whenever the court is contemplating an order that may have extraterritorial implications. To that end, I propose a test that may be characterized as a "comity-fueled conflict of laws" test that mediates the competing sovereign interests that an extraterritorial court order may implicate. ${ }^{25}$

The remainder of this paper will proceed in four parts. Part II describes the operation of Equity Extraterritoriality in greater detail by presenting a case study on how Equity Extraterritoriality applies U.S. law beyond the U.S. borders. Here, I note that the operation of Equity Extraterritoriality depends on two links of control: the court's control over a person, and the person's control over actions or things outside of the court's territorial jurisdiction. These links are, in engineering lingo, potential points of failure. When the strength of the control that makes up each link is compromised-either legally or practically - the links fail and create a problem.

Part III will offer a brief history of Equity Extraterritoriality, in which I argue that the origin of Equity Extraterritoriality may be traced to the landmark case of Pennoyer $v$. Neff, ${ }^{26}$ which applied territoriality principles to judicial jurisdiction but not to court orders issued after the jurisdiction was obtained. This section observes the growth of Equity Extraterritoriality in the early 20th century, when it saw a brief period of harmonization with jurisdictional extraterritoriality. Then this section describes the split in attitudes toward territoriality principles in the late 20th century, leading to

Welkowitz, Preemption, Extraterritoriality, and the Problem of State Antidilution Laws, 67 TUL. L. REV. 1, 2-4 (1992) (protection of intellectual property).

24. See Polly J. Price, Full Faith and Credit and the Equity Conflict, 84 VA. L. REV. 747, 751-92 (1998).

25. See discussion infra Section V.A.2.

26. 94 U.S. 714, 733 (1878). 
today's contradictory positions of jurisdictional extraterritoriality and Equity Extraterritoriality.

In Part IV, this paper will examine the Equity Extraterritoriality doctrine as it exists today, and identify its doctrinal problems. I first present the scale of the problems posed by Equity Extraterritoriality by focusing on a particular feature of modern economy: intangible properties. Because intangible properties have no physical situs, controlling intangible properties increasingly requires controlling the person who controls the intangible properties. Such a mode of indirect control coincides with the operation of Equity Extraterritoriality. Accordingly, the importance of Equity Extraterritoriality is bound to rise as intangible property becomes more important. Set against this background, I identify the two broad categories of problems presented by Equity Extraterritoriality: the problems arising from extraterritorial application of U.S. laws, and the problems arising from the doctrine's severe under-development and lack of limiting principles.

Finally in Part V, this paper will propose a solution, facilitating application of territorial principles to Equity Extraterritoriality. Here, I give greater attention to international Equity Extraterritoriality, as it is less developed and poses more significant problems relative to domestic Equity Extraterritoriality. I find that a solution must address the ultimate source of the problem of Equity Extraterritoriality, i.e. regulating the clashing claims of various sovereigns. For Equity Extraterritoriality in the domestic context, the U.S. Constitution provides sufficient legal principles and infrastructure to mediate such conflicts. International Equity Extraterritoriality, however, lacks an analogous superstructure. Here, I submit that the solution is to be discovered in the two legal theories whose purpose is to balance the different interests of sovereigns: the concept of international comity, and the mechanism of conflict of laws. To this end, I propose a legal test that may be characterized as a "comity-fueled conflict of laws," a more robust form of comity test that gives due respect for foreign sovereigns.

\section{UNDERSTANDING EQUITY EXTRATERRITORIALITY}

Equity Extraterritoriality is a concept that eludes a concise descriptive definition, precisely because the types of extraterritorial orders that the court can make are so varied. ${ }^{27}$ Many of these orders may be categorized as remedies (for example, extraterritorial injunctions) but many others are not remedies in the strict sense (for example, extraterritorial discovery orders).

27. See Spelling, supra note 14, at 5 ("The range of purpose for which this remedial writ [an injunction] may be invoked is almost infinite."). 
As discussed further below, the merger of law and equity created further confusion because court orders that were traditionally considered "legal" orders took on "equitable" characteristics post-merger. ${ }^{28}$ That is to say, although the term Equity Extraterritoriality points to the historical source of the court's power — namely, the power of courts sitting in equity ${ }^{29}$ — not all extraterritorial court orders can be characterized as equitable orders. ${ }^{30}$

The best way to understand this amorphous concept, then, is to observe the actual operation of Equity Extraterritoriality and see how it applies U.S. laws beyond U.S. borders. To that end, this section offers an extended example of Equity Extraterritoriality and discusses several other common variations of Equity Extraterritoriality.

\section{A. How Equity Extraterritoriality Governs Beyond Borders: a Case Study}

A brief exposition of one example of Equity Extraterritoriality may be helpful to demonstrate precisely how Equity Extraterritoriality is indeed an application of U.S. law beyond the U.S. courts' territorial jurisdiction. U.S. courts' collection of evidence located abroad is a good example of Equity Extraterritoriality. The courts' power to guide discovery under the Federal Rules of Civil Procedure originates from the courts' equitable powers. ${ }^{31}$ With this power, the court orders a person under its jurisdiction to take certain actions outside of its territorial jurisdiction-namely, preserve, collect, and produce physical evidence located outside the borders of the United States - and thereby regulates the pattern of foreign corporations' record keeping.

One must understand that discovery practice of U.S. courts is not merely rules of court administration, but a means of corporate governance in regards to corporate record-keeping. This is because, to a significant extent, discovery practice of U.S. courts dictates the routine business behavior of corporations. Under U.S. law, parties are required to preserve documents long before the actual commencement of the litigation, as soon as "a party

28. See discussion infra Section III.B.2.a.

29. See discussion infra Section III.A.

30. For example, writ of mandamus is traditionally considered a legal remedy. However, using this legal remedy, the court can order a government official to take actions beyond its territorial borders. In this sense, that mandamus is considered a legal remedy does not make it exempt from Equity Extraterritoriality.

31. See John H. Langbein, Fact Finding in the English Court of Chancery: a Rebuttal, 83 YALE L.J. 1620, 1630 (1974); Stephen N. Subrin, How Equity Conquered Common Law: The Federal Rules of Civil Procedure in Historical Perspective, 135 U. PA. L. REV. 909, 914-26 (1987); Rhonda Wasserman, The Subpoena Power: Pennoyer's Last Vestige, 74 MINN. L. REV. 37, 43-45 (1989) (tracing the origin of U.S. court's subpoena power to English Chancery procedures). 
reasonably anticipates litigation." 32 To satisfy this requirement, American businesses are advised to create a document retention policy regardless of whether they actually anticipate litigation in the near term. ${ }^{33}$ When litigation appears on the horizon, particularly in large commercial cases, it is common for a corporation to retain the (very expensive) services of an e-discovery vendor in order to properly preserve the documents and produce them as necessary. ${ }^{34}$ Failure to do so, in severe cases, may result in the literal death of the corporation, as was the case with the accounting firm Arthur Andersen LLP in the aftermath of the Enron scandal. ${ }^{35}$

This means that when a U.S. court orders a foreign corporation to produce documents and other physical evidence located outside of the territorial boundaries of the United States, the U.S. court is essentially mandating American-style corporate record keeping laws to foreign corporations. And U.S. courts quite frequently order foreign corporations to produce documents located outside of the courts' territorial jurisdiction. ${ }^{36}$ Several foreign corporations, sued in U.S. courts by U.S. plaintiffs, have been accused of failing to institute a U.S.-style litigation hold - a measure that is unheard of in their home jurisdiction.$^{37}$ One foreign corporation lost its litigation and became subject to a judgment in the amount of more than $\$ 920$ million, in large part because the corporation was sanctioned for spoliation of evidence after failing to preserve documents in the manner required by U.S. law. ${ }^{38}$ As a result, U.S.-style e-discovery vendors are hanging shingles throughout the world to assist foreign firms with Americanstyle document forensics. ${ }^{39}$ One could hardly find a surer sign of U.S. law's

32. Zubulake v. UBS Warburg LLC, 220 F.R.D. 212, 218 (S.D.N.Y. 2003); see also Bd. of Regents of the Univ. of Neb. v. BASF Corp., 2007 U.S. Dist. LEXIS 82492, at *14 (D. Neb. 2007) ("When the prospect of litigation is present, parties are required to preserve documents that may be relevant to the issues to be raised, and their failure to do so may result in a finding of spoliation of evidence.").

33. See Nat'l Fed. Of Ind. Business, NFIB Guide TO DEveloping A DRP 3 (2016) http://www.nfib.com/Portals/0/PDF/AllUsers/legal/guides/document-retention-policy-guide-nfib.pdf [https://perma.cc/3F7B-A7EC] (“A DRP [document retention policy] that is consistently followed may aid significantly in any litigation that might arise.").

34. See, e.g., FTI CONSUlTING, http://www.ftitechnology.com/.

35. See Arthur Andersen LLP v. United States, 544 U.S. 696, 698 (2005); see also Brandon L. Garrett, TOO BIG TO JAIL: How PROSECUTORS COMPROMISE WITH CORPORATIONS 19-44 (2014).

36. See Sant, supra note 23, at 181-84 (discussing the rise of extraterritorial discovery order that requires the party to break foreign laws).

37. See E.I. du Pont de Nemours \& Co. v. Kolon Indus., 803 F.Supp.2d 469, 505 (E.D. Va. 2011) (issuing order for adverse jury instruction and attorneys fee award for failing to preserve evidence); Apple Inc. v. Samsung Elecs. Co. Ltd., No. 11 civ 1846 (LHK) (PSG), slip op. at 1 (N.D. Cal. July 24, 2012) (requesting adverse jury instruction for spoliation of evidence).

38. See E.I. du Pont de Nemours \& Co. v. Kolon Indus., 894 F.Supp.2d 691, 691 (E.D. Va. 2012).

39. See, e.g., Deloitte Transactions and Business Analytics LLP, DeloitTe Discovery: ThE 
extraterritorial application than consultants who assist foreign companies to comply with American law while doing business outside of the United States.

Seeing the conflicts created by an order to produce extraterritorial evidence is another way to realize that such an order truly is an extraterritorial exercise of the court's power. The primary reason why there is a presumption against extraterritoriality is to avoid contravening an interest of a foreign sovereign. ${ }^{40}$ Yet an order to produce extraterritorial evidence routinely does exactly this. ${ }^{41}$ As the reporter of the Restatement (Third) of Foreign Relations put it: "No aspect of the extension of the American legal system beyond the territorial frontier of the United States has given rise to so much friction as the requests for documents in investigation and litigation in the United States."42 Many foreign nations have passed blocking statutes specifically in response to U.S.-style document discovery. ${ }^{43}$ But U.S. courts usually ignore this clearly-expressed preference of foreign sovereigns and order the persons under the courts' jurisdiction to submit extraterritorial evidence. ${ }^{44}$ Sometimes, U.S. court's challenge to foreign sovereign's interest in the context of discovery can be even more direct: as the Supreme Court recently pronounced in Republic of Argentina v. NML Capital, Ltd., a U.S. court may order extraterritorial discovery of foreign sovereign's assets as part of post-judgment discovery, regardless of the nature of the sovereign assets to be discovered. ${ }^{45}$ This deliberate rejection of foreign sovereign interests often puts a person under conflicting legal obligations - which, again, the U.S. courts usually ignore. ${ }^{46}$

Right TEAM FOR Your ORGANIZATION, at 17 (showing e-Discovery office locations in Amsterdam, Auckland, Bangkok, Beijing, Brussels, Buenos Aires, Cape Town, Calgary, Copenhagen, Dubai, Dublin, Dusseldorf, Edmonton, Frankfurt, George Town, Hong Kong, Hyderabad, London, Madrid, Melbourne, Mexico City, Milan, Moscow, Munich, Oslo, Paris, Prague, Pretoria, Sao Paolo, Santiago, Seoul, Shanghai, Sydney, Tokyo, Toronto, Vancouver, Vienna and Zurich), available at http://www2.deloitte.com/content/dam/Deloitte/us/Documents/finance/us-advisory-discovery.pdf.

40. See Am. Banana Co. v. United Fruit Co., 213 U.S. 347, 355-58 (1909).

41. See Sant, supra note 23, at 212-25.

42. Restatement (Third) of Foreign Relations $\S 442$, n.1.

43. See id.

44. See Sant, supra note 23, at 185 .

45. 134 S.Ct. 2250, 2258 (2014). See also Aaron D. Simowitz, Transnational Enforcement Discovery, 83 FORDHAM L. REV. 3293 (2015) (discussing NML Capital in the context of post-judgment discovery).

46. See Sant, supra note 23, at 212-21; see also First Nat'l City Bank of New York v. Internal Revenue Service, 271 F.2d 616, 618-19 (2d Cir. 1959) (rejecting the conflicting obligation created by Panama's bank secrecy laws). For examples of other types of Equity Extraterritoriality that puts a foreign corporation under inconsistent legal obligations, see Fargo v. Redfield, 22 F. 373, 375 (1st Cir. 1884); United States v. Bank of Nova Scotia, 740 F.2d 817, 828 (11th Cir. 1984) (rejecting the claim by a 
No matter-one may object: isn't submitting to the U.S. court's jurisdiction (and dealing with occasional inconsistent judgments) the price that a corporation must pay for doing business in the United States? ${ }^{47}$ As long as Equity Extraterritoriality orders persons under the court's jurisdiction, what is the problem? Yet a U.S. court need not have jurisdiction over the foreign party to extend its power beyond its territorial jurisdiction. This is so because extraterritorial application of the law is not merely a collection of instances in which a nation directly enforces its laws outside of the national borders. A speed limit over a stretch of highway governs the entire stretch, even if the police catch only a fraction of the drivers who violate the speed limit. Similarly, even with statutes that explicitly authorize extraterritorial enforcement, actual enforcement is at best intermittent. As Professor Jack Goldsmith noted, extraterritorial application of the law may mean that "a nation uses the threat of force against local persons or property to punish, and thus regulate, extraterritorial acts." 48 To govern extraterritorially, a U.S. court only needs to raise the threat that a foreign party may be hauled into litigation in the United States. A foreign firm must comply with the U.S.-style document preservation at all times (or risk a disastrous litigation outcome), as long as there is at least some chance of litigation in the United States. And there is always some chance, because the U.S. legal doctrine on personal jurisdiction is notoriously far-reaching and unpredictable. $^{49}$ If a foreign firm does business with the United States, the firm simply cannot afford to refuse U.S.-style document forensics because chances are good that the foreign firm will be subject to U.S. jurisdiction. In other words, U.S. courts' extraterritorial discovery orders, set against the uncertain American legal doctrine on personal jurisdiction, regulate the document retention behaviors of the corporations outside of the court's territorial jurisdiction long before a U.S. court actually establishes personal jurisdiction over any such corporation.

Canadian bank that a U.S. court order would subject it to conflicting enforcement obligations). See also discussion infra Section IV.B.3.

47. See Bank of Nova Scotia, 740 F.2d at 828 (if a foreign corporation "voluntarily elected to do business in numerous foreign host countries," it "has accepted the incidental risk of occasional inconsistent governmental actions. It cannot expect to avail itself of the benefits of doing business here without accepting the concomitant obligations.").

48. Jack L. Goldsmith, The Internet and the Abiding Significance of Territorial Sovereignty, 5 IND. J. Global LeGAL Stud. 475, 479 (1998) (emphasis added).

49. See James Weinstein, The Federal Common Law Origins of Judicial Jurisdiction: Implications for Modern Doctrine, 90 VA. L. REV. 169, 171 (2004) (“Although the extensive body of commentary on federally imposed limitations on state court jurisdiction agrees on very little, the one point of consensus is that Supreme Court personal jurisdiction doctrine is deeply confused."). See also discussion on longarm jurisdiction infra Sections II.B.3.b and III.A.1. 


\section{B. The Operation of Equity Extraterritoriality}

As discussed above, Equity Extraterritoriality is a concept that eludes a concise descriptive definition. But through the aforementioned example, one can discern how the doctrine operates and reaches beyond the court's territorial jurisdiction.

Equity Extraterritoriality is an indirect form of extraterritoriality. A typical Equity Extraterritoriality situation is one in which a court obtains jurisdiction over a person, and then orders the person to take certain actions beyond the court's territorial jurisdiction. In other words, Equity Extraterritoriality operates in transnational litigation through two links of control: the court's control over a person, and the person's control over an extraterritorial thing or conduct. ${ }^{50}$ The first link - the court's control over the person-corresponds to personal jurisdiction, i.e. the court's ability to have a person appear before the court. The second link - the order that the court issues on the person - is the province of Equity Extraterritoriality.

Equity Extraterritoriality may arise in two ways, domestic and international: a court of one state may issue an extraterritorial order binding persons and conduct in another state, or a U.S. court may issue an extraterritorial order binding persons and conduct in another country. Although U.S. jurisprudence views both types as qualitatively the same, international Equity Extraterritoriality is the more significant problem, as it is simultaneously less developed than domestic Equity Extraterritoriality and creates the more significant foreign policy implications. ${ }^{51}$

The visualization of transnational litigation as a chain with two links allows one to focus on the nature of the problems posed by Equity Extraterritoriality. Fundamentally, the problem of Equity Extraterritoriality is that the application of territoriality principles or, protection against extraterritoriality, occurs only on the first link, but not on the second. Through such legal doctrines as personal jurisdiction that largely operate on a territorial basis and on a presumption against extraterritoriality, U.S. jurisprudence applies the territoriality principles on the first link of the chain, the front end of the litigation. Once the court obtains personal jurisdiction and reaches the second link, there is virtually no application of territoriality principles in the extraterritorial orders that the court may fashion. To be sure, the courts are admonished to be circumspect about their ability to enforce their extraterritorial orders, ${ }^{52}$ and they do frequently decline to issue

\footnotetext{
50. See discussion infra Sections IV.B.3. and IV.C.1.

51. See discussion infra Section III.C.4.

52. See Charles Alan Wright and Arthur R. Miller, 11A FED. PRAC. \& P.: CiV. § 2945 ("[V]arious
} 
extraterritorial orders on this basis. ${ }^{53}$ However, the court's sense of discretion fails frequently, leading to problems typically associated with extraterritorial application of national laws. Further, as discussed in more detail below, the problems of Equity Extraterritoriality - the second link of the chain — puts additional pressure on the first link of the chain, hindering the internal consistency of the personal jurisdiction doctrine. ${ }^{54}$

\section{HISTORY OF EQUITY EXTRATERRITORIALITY}

The term "Equity Extraterritoriality" points to the historical origin of the court's indirect extraterritorial authority - namely, the equity tradition. This section offers a brief history of Equity Extraterritoriality's doctrinal development, set against the development of jurisdictional extraterritoriality to highlight the relative neglect that Equity Extraterritoriality has received.

\section{A. Birth of Equity Extraterritoriality in Pennoyer v. Neff}

Equity Extraterritoriality as a doctrine came into being in the landmark case of Pennoyer $v$. Neff. ${ }^{55}$ However, the potential for Equity Extraterritoriality existed long before the United States was established. Before the American Revolution, the English equity court freely reached beyond its territorial jurisdiction-typically, to adjudicate cases involving lands located outside of England. ${ }^{56}$ This was in marked contrast to the common law courts of England, which operated on a territorial basis. It was held as early as 1280 that common law courts had no jurisdiction to redress a tort committed abroad. ${ }^{57}$ It was not until 1605 that a jury was permitted to determine a foreign fact. $^{58}$ In the early 17 th century, common law courts began considering cases involving obligations made outside of England, but

considerations may induce [the court] to refrain from exercising this power in certain contexts."); Restatement (Third) of Foreign Relations $\S 442 \mathrm{cmt} .2$ n.2 (cautioning against ordering extraterritorial discovery).

53. See, e.g., Blue Ribbon Feed Co. v. Farmers Union Cent. Exch., 731 F.2d 415, 422 (7th Cir. 1984); Republic of Philippines v. Westinghouse Elec. Corp., 43 F.3d 65, 80 (3d Cir. 1994).

54. See discussion infra Section IV.C.3.

55. 95 U.S. 714, 724 (1878).

56. See, e.g., Carteret v. Petty (1676) 2 Swans 324, 324 (Chancery Court ordering accounting waste in lands located in Ireland); Arglasse v. Muschamp 23 Eng. Rep. 322, 323 (1682) (Chancery Court issuing bill of relief against annuity charged on Irish lands); Toller v. Carteret (1705) 2 Vern. Ch. 494, 495 (Chancery Court adjudicating a matter concerning mortgage of lands located in the island of Sark, in Channel Islands); Penn v. Lord Baltimore (1750) 1 Ves. Sr. 444, 447 (adjudicating the boundary dispute between England's North American colonies, Pennsylvania and Maryland).

57. See Huge le Pape v. the Merchants of Florence in London, 8-9 Edw. I (1280-1281); Alexander N. Sack, Conflicts of Laws in England, LAw: CENTURY OF PROGRESS 1835-1935 342, 344 (1937).

58. See Dowdale's Case, 6 Co. Rep. 46(b) (1605); Sack, supra note 57, at 347-48. 
only by relying on a ludicrous legal fiction that a foreign city was actually in England. ${ }^{59}$ The early courts of the United States inherited this split attitude on territoriality, with courts sitting in law operating on the basis of territoriality $^{60}$ while courts sitting in equity reaching freely beyond its territorial jurisdiction. ${ }^{61}$ Early Supreme Court cases reflect a similar split. Several early cases (including Charming Betsy, in which the court held "an act of Congress ought never to be construed to violate the law of nations if any other possible construction remains") follow the territoriality principles. $^{62}$ But in the same time period, the Supreme Court regularly allowed state courts sitting in equity to reach beyond their territorial jurisdiction. $^{63}$

59. For example in Ward's case, decided in 1625, the plaintiff sued based on a debt on bill created in Hamburg, Germany. In the judgment entered for the plaintiff, the court declared (presumably with a straight face): "we shall take it that Hamburg is in London in order to maintain the action which otherwise would be without our jurisdiction, and while in truth we know that Hamburg is beyond the sea, as judges we do not take notice that it is beyond the sea." 82 Eng. Rep. 244, 245 (1624-1628); see also Sack, supra note 57 , at 346 .

60. See, e.g., Kibbe v. Kibbe, 1 Kirby 119, 126 (Conn. Super. Ct. 1786) (holding courts of Massachusetts lacked jurisdiction against a Connecticut resident because the plaintiff in the Massachusetts action failed to personally serve process on the Connecticut defendant within Massachusetts); Kilburn v. Woodworth, 5 Johns. 37, 41 (N.Y. Sup. Ct. 1809); Rogers v. Coleman, 3 Ky. (Hard.) 422, 429 (1808). For additional examples of early American, pre-Pennoyer cases that discuss the court's territorial jurisdiction, see Weinstein, supra note 3, at 11 (collecting cases).

61. See, e.g., Farley v. Shippen, Wythe (Va.) 254, 265 (1794) (Supreme Court of Virginia ordering a party to convey lands located in North Carolina); Sanford v. Sanford, 5 Day (Conn.) 353, 358 (1812) (Connecticut court ordering delivery of personal property outside of the state's territorial boundaries); Jennison v. Hapgood, 27 Mass. 77, 110 (1830) (Massachusetts court ordering disposition of property outside of Massachusetts); Mitchell v. Bunch, 2 Paige Ch. (N.Y.) 606, 621 (1831) (New York court ordering the defendant to deliver personal property from Cartagena, Colombia); Mead v. Merritt, 2 Paige Ch. (N.Y.) 402, 405 (1831) (New York court ordering the defendant to convey real estate in Connecticut); McDowell v. Read, 3 La. Ann. 391, 395 (1848) (Louisiana determining the legality of conveyance of lands located outside of Louisiana); Dickinson v. Hoomes's Administrator, 49 Va. 353, 439 (1852) (Virginia court ordering conveyance of real estate in Kentucky); MacGregor v. MacGregor, 9 Iowa 65, 77 (1859) (Iowa court ordering conveyance of real estate in Illinois and Wisconsin); Gardner v. Ogden, 22 N.Y. 327, 332 (1860) (New York court ordering conveyance of real estate in Illinois); Burnley v. Stevenson, 24 Ohio St. 474, 477 (1873) (Ohio court ordering conveyance of real estate in Kentucky); Moore v. Jaeger, 2 MacArth. (D.C.) 462, 471 (1876) (District of Columbia court ordering conveyance of land in West Virginia); Henderson v. McBee, 79 N.C. 219, 222 (1878) (North Carolina court ordering conveyance of real estate in Alabama); Seixas v. King, 39 La. Ann. 510, 512 (1887) (Louisiana court ordering conveyance of real estate in Mississippi); Winn v. Strickland, 34 Fla. 610, 631 (1894) (Florida court ordering conveyance of real estate in Georgia).

62. Schooner Charming Betsy, 6 U.S. (2 Cranch) at 118. Although the canon is phrased as a rule of statutory interpretation, the territoriality principle that underlies the canon is readily visible because in the early 19th century, the "law of nations" was almost entirely concerned with the relationship among territorially sovereign states. See also The Schooner "Exchange" v. M'Faddon, 11 U.S. (7 Cranch) 116, 136 (1812) (holding Maryland court had no jurisdiction to adjudicate on French warship).

63. See, e.g., Massie v. Watts, 10 U.S. 148, 163 (1810) (allowing Kentucky court to compel 
But it was not until Pennoyer v. Neff that the Supreme Court had the occasion to consider applying the territoriality principles to equitable remedies, and decided that they did not apply. Accordingly, Pennoyer may be considered the moment of birth for Equity Extraterritoriality, in which the doctrine "found its highest expression." 64

The facts of Pennoyer are well-known. Marcus Neff, who was the plaintiff at the trial level, sought to recover the title of the land in Oregon that was sold to Sylvester Pennoyer. Pennoyer acquired the land from John Mitchell, who purportedly obtained title of Neff's land after prevailing in a lawsuit against Neff. Unlike Mitchell, Neff did not reside in Oregon, and never appeared on the lawsuit that Mitchell filed. Mitchell served Neff by publication pursuant to Oregon law, and won a default judgment when Neff failed to appear. Therefore, the validity of Pennoyer's title depended on the validity of Mitchell's default judgment. And the validity of the Mitchell's judgment, in turn, depended on whether Oregon had jurisdiction over Neff when Mitchell sued Neff.

Much of Pennoyer is about the application of territoriality principles to the doctrine of personal jurisdiction. Pennoyer imported its territoriality principles from Joseph Story, who in turn borrowed and expanded the territoriality principles of the Dutch jurist Ulrich Huber. Huber's theory of territorial sovereignty, under which laws of a sovereign state are effective within the state's territory but not beyond, formed the foundation of the Westphalian international order. ${ }^{65}$ Story inherited Huber's principles, and transformed them into rules limiting judicial jurisdiction along the lines of territorial boundaries. ${ }^{66}$ In doing so, Story transformed "intellectual

conveyance in lands located in Ohio); King v. Hamilton, 29 U.S. 311, 311 (1830) (ruling the circuit court of Ohio, sitting in Equity, may order specific performance regarding land located within the military grant given by Ohio to Virginia); Watkins v. Lessee of Holman, 41 U.S. 25, 57 (1842) ("A Court of Chancery, acting in personam, may well decree the conveyance of land in any other state, and may enforce their decree by process against the defendant."); Corbett v. Nutt, 77 U.S. 464, 475 (1870) (“A court of equity acting upon the person of a defendant may control the disposition of real property belonging to him situated in another jurisdiction, and even in a foreign country."); Muller v. Dows, 94 U.S. 444, 449 (1876) ("It is here undoubtedly a recognized doctrine that a court of equity, sitting in a State and having jurisdiction of the person, may decree a conveyance by him of land in another State, and may enforce the decree by process against the defendant."); Phelps v. McDonald, 99 U.S. 298, 308 (1878) ("Where the necessary parties are before a court of equity, it is immaterial that the res of the controversy, whether it be real or personal property, is beyond the territorial jurisdiction of the tribunal.").

64. Price, supra note 24 , at 804 .

65. See Alex Mills, The Private History of International Law, 55 INT'L \& COMP. L.Q. 1, 25-27 (2005).

66. See Geoffrey C. Hazard, Jr., A General Theory of State-Court Jurisdiction, 1965 SuP. CT. REV. 241,260 (1965). 
constructs for critical enlightenment" into the principles of "administering the law in its intricate routine." ${ }^{\prime 7}$

The opinion in Pennoyer borrows its jurisdictional principles directly from Story: "no tribunal established by [a state] can extend its process beyond that territory so as to subject either persons or property to its decisions. 'Any exertion of authority of this sort beyond this limit,' says Story, "is a mere nullity.",68 But how is a state to establish the required jurisdiction over the party? Here, Pennoyer announced the decision for which it is primarily known today: by serving the defendant personally. This is the contribution from the English common law concept of territoriality, which was transplanted to the early American common law courts. Early American common law courts had a form of territoriality principle whereby their jurisdiction was established by a service of process effectuated within the state boundaries. ${ }^{69}$ In short, Pennoyer grafted the Westphalian territoriality principles-derived from Huber's theories, delivered through Story - onto the jurisprudence on personal jurisdiction, by requiring a territorial service of process upon a person before the courts may exercise jurisdiction over that person.

But what about after the court establishes personal jurisdiction? At that point, do territoriality principles apply to the orders that the court may issue upon the person over whom the court has jurisdiction? To this core question of Equity Extraterritoriality, the Supreme Court answered simply: no. In the middle of propounding the strong territoriality principles inherited from Huber and Story, the Supreme Court gave this ringing endorsement of Equity Extraterritoriality:

[T] he exercise of jurisdiction which every State is admitted to possess over persons and property within its own territory will often affect persons and property without it. To any influence exerted in this way by a State affecting persons resident or property situated elsewhere, no objection can be justly taken.

Thus the State, through its tribunals, may compel persons domiciled within its limits to execute, in pursuance of their contracts respecting property elsewhere situated ...; and the exercise of this jurisdiction in no manner interferes with the supreme control over the property by the State within which it is situated. ${ }^{70}$

The Court concluded this approval of Equity Extraterritoriality by citing a line of English and American cases that upheld the central thesis of Equity

\footnotetext{
67. Id.

68. Pennoyer v. Neff, 95 U.S. at 722-23.

69. See Weinstein, supra note 3, at 10.

70. Pennoyer, 95 U.S. at 723.
} 
Extraterritoriality: once there is jurisdiction over a person, the court may reach beyond its territorial borders by way of ordering that person. ${ }^{71}$

To be sure, Pennoyer's approval of Equity Extraterritoriality comes in dicta, and its formulation of Equity Extraterritoriality is the same as the many prior Supreme Court cases that allowed courts sitting in equity to exercise an indirect extraterritorial authority. ${ }^{72}$ But the context in which the formulation appeared does matter. In the middle of pronouncing perhaps the strongest statement of territoriality in U.S. constitutional history, the Supreme Court explicitly carved an exception: as long as the court exercised its power beyond its territorial jurisdiction indirectly through persons within its territorial jurisdiction, "no objection can be justly taken."

According, Pennoyer is the moment where Equity Extraterritoriality had its doctrinal birth. But of course, the court's a priori approval of Equity Extraterritoriality begs the question: regardless of what the Supreme Court says, there must be some instances where Equity Extraterritoriality does interfere with another state's territorial sovereignty as a practical matter. What happens in those instances? To this day, nearly 140 years since Pennoyer, the Supreme Court has not given a comprehensive answer.

\section{B. Growth of Equity Extraterritoriality in Early and Mid-20th Century}

Pennoyer, decided in 1878, crystallized the split in the application of territoriality doctrine in the U.S. law: jurisdiction would be delimited by the territorial boundaries, while equity would reach beyond the territorial boundaries through persons under the court's jurisdiction. In the early 20th century, these two branches would continue stretching in opposite directions. Two developments from the mid-20th century would accelerate the split even further: merger of law and equity, and the personal jurisdiction revolution involving "minimum contacts" and the "effects" test. These two developments would serve as growth spurts for Equity Extraterritoriality, which emerged as an even more significant force by late 20th century.

\section{Equity Extraterritoriality in the Early 20th Century}

The split in the territoriality doctrine caused by Pennoyer continued into the 20th century: territoriality principles applied to jurisdiction, but not to court orders thereafter. In American Banana Co. v. United Fruit Co., the Supreme Court applied Pennoyer's concept of territoriality to legislative jurisdiction, holding that an act of Congress (in this case, Act to Protect

\footnotetext{
71. Id.

72. See cases cited supra note 63.
} 
Trade Against Monopolies) did not apply to injuries occurring outside the territorial boundaries of the United States. ${ }^{73}$ If Pennoyer is not the strongest statement of territorial sovereignty in U.S. constitutional history, the honor may belong to American Banana. The Court's opinion, penned by Justice Oliver Wendell Holmes, expresses incredulity that anyone would doubt the idea that American law did not apply beyond the U.S. territorial borders:

[T] he plaintiff's case depends on several rather startling propositions. In the first place the acts causing the damage were done, so far as appears, outside the iurisdiction of the United States ... It is surprising to hear it argued that they were governed by the act of Congress. ${ }^{74}$

Justice Holmes also made clear that sovereignty was the animating principle of the territoriality doctrine, as he found extraterritorial application of a Congressional act "would be an interference with the authority of another sovereign." 75

At the same time, however, the Supreme Court continued to find no issue with Equity Extraterritoriality, which at this point had received the blessings of Pennoyer. In the aftermath of Pennoyer, the courts of the United States continued to approve the Equity Extraterritoriality power to order disposition of res located outside of the courts' territorial jurisdiction. ${ }^{76}$ Commentators from the early 20th century have considered Equity Extraterritoriality to be a settled doctrine: "It is now firmly established that the courts of equity of one state can grant an injunction to restrain the proceedings in another state without interfering with the sovereignty of that other state." $" 77$

73. 213 U.S. 347, 357 (1909).

74. Id. at 355 .

75. Id. at 356; see also Foley Bros., Inc. v. Filardo, 336 U.S. 281, 290 (1949) (U.S. overtime laws did not apply outside of the United States, despite the fact that both the employer and the employee were U.S. nationals).

76. See, e.g., Robertson v. Howard, 229 U.S. 254, 261-62 (1913); Fall v. Eastin, 215 U.S. 1, 10 (1909); Carpenter v. Strange, 141 U.S. 87, 105-06 (1891); Hart v. Sansom, 110 U.S. 151, 154-55 (1884); Lawrence v. Du Bois, 16 W. Va. 443, 455-56 (1880); Shillaber v. Robinson, 97 U.S. 68, 71-72 (1877); Elizabethtown Sav. Inst. v. Gerber, 35 N.J. Eq. 153, 156-57 (1882); Johnson v. Gibson, 6 N.E. 205, 208 (Ill. 1886); Peters v. Neely, 84 Tenn. 275, 280-81 (1886); Smith v. Davis, 27 P. 26, 32 (Cal. 1891); Davis v. Cornue, 45 N.E. 449, 450-51 (N.Y. 1896); Noble v. Grandin, 84 N.W. 465, 467 (Mich. 1900); Pittsburg, C., C. \& St. Louis Ry. Co. v. Bartels, 56 S.W. 152, 152 (Ky. 1900); Schmaltz v. York Mfg. Co., 52 A. 522, 526 (Pa. 1902); Butterfield v. Nogales Copper Co., 80 P. 345, 347 (Ariz. 1905); Banco Minero v. Ross, 172 S.W. 711, 714 (Tex. 1915); Apple v. Smith, 190 P. 8, 9 (Kan. 1920).

77. Ernest J. Messner, The Jurisdiction of a Court of Equity Over Persons to Compel the Doing of Acts Outside the Territorial Limits of the State, 14 MINN. L. REV. 494, 495 (1930); see also Charles Levin, Extra-Territorial Jurisdiction of Courts of Chancery, 9 NOTRE DAME L. REV. 399, 407 (1934) ("It is apparently well-established in this country that, on the theory that the action is purely one in personam, and not in rem, a court does have equitable power to make such an [extraterritorial] order.") (italics in original); Walter W. Cook, The Power of Courts in Equity, Part II, 15 COLUM. L. REV. 106, 128 (1915); 
By the early 20th century, now with Pennoyer's blessing, Equity Extraterritoriality would not limit itself to the "classical" situations in which Equity Extraterritoriality arose in the 19th century - usually, adjudication of rights regarding a specific real property located outside of the court's territorial jurisdiction. As the economy of the United States expanded throughout North America and beyond in the late 19th century and early 20th century, there was an ever-greater need for American parties before a U.S. court to exercise control beyond the territorial jurisdiction of the court. Accordingly, Equity Extraterritoriality would find new expressions with even greater extraterritorial impact. With Equity Extraterritoriality, courts of the early 20th century were able to: order a party to deliver physical evidence located outside of the court's territorial jurisdiction; ${ }^{78}$ order a party to stop pursing legal action with a court of another jurisdiction; ${ }^{79}$ order a party to engage in a construction project outside of the United States so as to prevent harmful environmental effects within the U.S. ${ }^{80}$ prohibit a non-U.S. corporation from changing prices outside of the United States, although the price change was mandated by a foreign law. ${ }^{81}$ Every one of these expressions of Equity Extraterritoriality survives to this day.

Spelling, supra note $14, \S 8$, at 10 ("But a court of equity may enjoin one from prosecuting a suit or selling property in another state, if justice so requires.").

78. See, e.g., Consolidated Rendering Co. v. Vermont, 207 U.S. 541, 551 (1908) (finding no Due Process Clause violation when a Vermont grand jury ordered production of defendant company's books and records located in Massachusetts); Blackmer v. United States, 284 U.S. 421, 443 (1932) (upholding a contempt judgment over an American citizen residing abroad who refused to comply with a subpoena in a criminal case).

79. See, e.g., Cole v. Cunningham, 133 U.S. 107, 134 (1890) (permitting Massachusetts courts to enjoin the defendants from continuing the litigation pending in New York). In Cole, the enjoined party cited Pennoyer to argue against the anti-suit injunction by the Massachusetts court. Quoting the very language in Pennoyer that approved Equity Extraterritoriality, the court found that extraterritorial antisuit injunctions were permitted. See also Wilson v. Josephs, 8 N.E. 616, 617 (Ind. 1886) (Indiana court enjoining the defendant from pursuing an attachment action in Illinois); Allen v. Buchanan, 11 So. 777, 779 (Ala. 1893) (Alabama court enjoining a legal proceeding against property in Louisiana); Miller v. Gittings, 37 A. 372, 376-77 (Md. 1897) (Maryland court enjoining customers from suing a Maryland broker in New York); Dunlap v. Byers, 67 N.W. 1067, 1071 (Mich. 1896) (Michigan court upholding the validity of an Ohio court order adjudicating claims over lands located in Michigan); Kirdahi v. Basha, 74 N.Y.S. 383, 384 (1902) (New York court enjoining disposition of property located in New Jersey); Greenberg v. Greenberg, 218 N.Y.S. 87, 98 (N.Y. App. Div. 1st Dep’t 1926) (New York court enjoining a husband from prosecuting a divorce action in a foreign country).

80. See, e.g., The Salton Sea Cases, 172 F. 792, 819-20 (9th Cir. 1909) (upholding the California court's order enjoining a New Jersey corporation from diverting water in Mexico in order to stop the flooding in Utah). Salton Sea is notable because, although the court had no territorial jurisdiction over the defendant (a New Jersey corporation), the loci delicti (Mexico), or the damaged res (land in Utah), the court made the extraterritorial order solely based on long-arm personal jurisdiction over the defendant.

81. See, e.g., Fargo v. Redfield, 22 F. 373, 375-76 (1st Cir. 1884) (prohibiting a Canadian railway company from adjusting the fares on the rail tracks that stretched into Vermont based on the contract 
The problem caused by the growing split in the application of territoriality principles was becoming increasingly apparent to courts and legal scholars of the early 20th century. Regardless of what the Supreme Court declared in Pennoyer, it was plain that at least in certain circumstances, Equity Extraterritoriality was inconsistent with the territoriality principle applied to judicial and legislative jurisdiction, and served as an affront to the principle of territorial sovereignty. Contemporary scholars were quite forward in noting that Equity Extraterritoriality allowed a party to do what it could not under the ordinary application of the territoriality principles. ${ }^{82}$ Thus, eminent jurists of this time period attempted to find a limiting principle for Equity Extraterritoriality.

Justice Oliver Wendell Holmes appears to be the first Supreme Court justice who paused at the state of the law regarding territoriality. In Fall v. Eastin, the plaintiff fell on the "wrong" side of Equity Extraterritoriality, as the plaintiff's divorce decree from the state of Washington ordered that the title of the land located in Nebraska should be changed to list the plaintiff as the land owner. ${ }^{83}$ The majority opinion by Justice Joseph McKenna decided the case along the lines of Pennoyer: the Washington court cannot affect the title of the land in Nebraska, although the plaintiff could have prevailed if the decree merely ordered the defendant to deliver the title of the land. ${ }^{84}$ Perhaps mindful of the strong territoriality principle that he announced in American Banana, decided only seven months prior to Fall, Justice Holmes penned a concurring opinion to find a place for Equity Extraterritoriality

between the Canadian company and a Vermont rail company, although Canadian law required the fare adjustment). Fargo is striking because around the same time Fargo was decided, the U.S. Supreme Court repeatedly held in several railroad cases that courts of one state could not regulate the railway management of another state. See, e.g., N. Ind. R.R. Co. v. Mich. Cent. R.R. Co., 56 U.S. 233, 246 (1854); Miss. \& Mo. R.R. Co. v. Ward, 67 U.S. 485, 496 (1863); Cent. R.R. Co. v. Jersey City, 209 U.S. 473, 480 (1908). Thus, Fargo is an example of one of the most significant problems of Equity Extraterritoriality: it allows a court to do indirectly what it is prohibited to do directly. See further discussion infra Section V.B.2.c.

82. See Cook, supra note 77, at 110 ("We are now in a position to see to what extent these methods of procedure really differ. In practical effect there is some but only a little difference."); Messner, supra note 77, at 528 ("The tendency of the modern decisions is to pay less attention to the state lines, which formerly were considered insurmountable barriers, and, when the court has personal jurisdiction over the parties to the suit, to render any suitable decree, directed to and binding upon the parties to the suit, even to the extent of directing an act to be done outside of the state."). See also Israel S. Gomborov, ExtraTerritorial Jurisdiction in Equity, 7 TEMP. L.Q. 468, 474-76 (1933) (criticizing early Supreme Court cases on Equity Extraterritoriality on the grounds that they violate the principle of territorial sovereignty).

83. 215 U.S. 1, 4 (1909).

84. See id. at 8 ("The territorial limitation of the jurisdiction of courts of a state over property in another state has a limited exception in the jurisdiction of a court of equity, but it is an exception well defined. A court of equity, having authority to act upon the person, may indirectly act upon real estate in another state, through the instrumentality of this authority over the person."). 
within the constitutional structure. To Justice Holmes, the justification for Equity Extraterritoriality could be found in the Constitution's Full Faith and Credit Clause: "A personal decree is equally within the jurisdiction of a court having the person within its power, whatever its ground and whatever it orders the defendant to do. Therefore, I think this decree was entitled to full faith and credit in Nebraska." ${ }^{85}$ Justice Holmes, however, found other defects in the Washington court's order that disqualified it from full faith and credit. $^{86}$

This formulation by Justice Holmes is not a great solution. For one, it does nothing to limit the reach of Equity Extraterritoriality, as Justice Holmes would permit the court to reach extraterritorially in "whatever it orders the defendant to do," as long as the court has the person "within its power." For another, Justice Holmes' solution would do nothing in the international context, which has no equivalent of a Full Faith and Credit Clause. Regardless, Justice Holmes' concurring opinion in Fall appears to be the first attempt by the Supreme Court to limit the Equity Extraterritoriality doctrine with a constitutional mandate. If engaged further, Fall v. Eastin could have developed into a more robust Equity Extraterritoriality doctrine that developed within the confines of the Full Faith and Credit jurisprudence. But not much came of Fall; Justice Holmes' proposed formulation of Equity Extraterritoriality only led to minimal further development, ${ }^{87}$ leading to Justice Breyer's bewilderment 87 years later in Baker, where the Supreme Court was asked to ascertain the relationship between Equity Extraterritoriality and the Full Faith and Credit Clause. $^{88}$

Judge Learned Hand, another titan of American legal history, tackled this issue as well. The plaintiff in Amey v. Colebrook Guaranty Savings Bank filed suit in the U.S. District Court for Vermont to demand accounting over lands located in Maine. ${ }^{89}$ In this "classic" Equity Extraterritoriality case, Judge Hand shrewdly noted that Amey presented the same problem that Justice Holmes faced in Fall. ${ }^{90}$ In Amey, Judge Hand took a different tack from Justice Holmes by explicitly seeking to limit the application of Equity

85. Id. at 15 (Holmes, J., concurring).

86. See id.

87. In Sherrer v. Sherrer, 334 U.S. 343, 352 (1948), the Supreme Court held that divorce decrees were entitled to Full Faith and Credit across state borders. But neither Sherrer nor any other Supreme Court case since Justice Holmes' concurring opinion in Fall dealt with Equity Extraterritoriality until Baker in 1996.

88. See Baker v. Gen. Motors Corp., 522 U.S. 222 (1998).

89. 92 F.2d 62, 62 (2d Cir. 1937).

90. See id. at 64 (citing Fall v. Eastin, 215 U.S. 1, 1 (1909)) 
Extraterritoriality. Responding to the argument that the court had jurisdiction over the defendant, Judge Hand noted:

The word, "jurisdiction," is in this connection somewhat equivocal; in one sense the judge had it; the [defendant] had personally appeared and was subject to his orders ... But although he thus had the power to prevent the defendant from asserting its rights in Maine, it might still be improper for him to do so. Courts do not always exert themselves to the full, or direct parties to do all that they can effectively compel, and such forbearance is sometimes called lack of "jurisdiction." 91

With this, Judge Hand was attempting to limit the worst excesses of Equity Extraterritoriality by limiting the basis upon which a court may issue an extraterritorial order. For Judge Hand, merely having jurisdiction over a person would not be sufficient. After detailed discussion of English and American cases on Equity Extraterritoriality, Judge Hand concluded: "It would be more nearly true to say that the court may enforce any personal obligation of the defendant ... When there is no such obligation, under the more general rule and the better considered decision, courts will abstain." 92 In other words, Judge Hand would allow Equity Extraterritoriality to reach beyond the court's territorial borders to enforce a specific obligation, such as a pre-existing contract or a judgment by a court, but not a general obligation such as the duty to avoid waste, as was the case in Amey. This limitation would have cut down the many branches of Equity Extraterritoriality to a manageable level — but it was not to be. The only time the U.S. Supreme Court addressed Judge Hand's limiting principle was in Justice John Harlan's dissent in United States v. First National City Bank, while the majority of the court continued the path of Equity Extraterritoriality. ${ }^{93}$ Beyond that moment of hurrah, Judge Hand's limiting doctrine received little notice. ${ }^{94}$

91. Id. at 63 (emphasis in original).

92. Id. at 64 (emphasis added).

93. 379 U.S. 378, 387-388 (1965) (Harlan, J., dissenting) ("But 'jurisdiction' is not synonymous with naked power. It is a combination of power and policy. Judge Learned Hand made this point in Amey, a case containing some of the same elements as the case before us.") (internal citation omitted).

94. Only two federal cases cite Judge Hand's limiting principle with approval. Gillis v. Keystone Mut. Casualty Co., 172 F.2d 826, 830 (6th Cir. 1949); Connell v. Algonquin Gas Transmission Co., 174 F. Supp. 453, 457 (D.R.I. 1959). See also Notes, RestATEMENT (SECOND) OF CONFLiCT OF LAWs (AM. LAW INST. 1971) $§ 55$ (citing Amey in a section that allows a state to issue an extraterritorial injunction as long as the person so ordered is within the court's judicial jurisdiction). 
2. Two Growth Spurts: Merger of Law and Equity, and the Personal Jurisdiction Revolution

Equity Extraterritoriality grew and expanded steadily in the early 20th century, despite attempts by eminent jurists to limit its reach. In the mid20th century, Equity Extraterritoriality would undergo two major growth spurts that would push its reach even further away from the principle of sovereign territoriality: merger of law and equity, and the revolution in the U.S. law's personal jurisdiction doctrine.

\section{a. Merger of Law and Equity}

The merger of law and equity was the first growth spurt for Equity Extraterritoriality. In the federal system, law and equity ceased to exist as separate systems in 1938 with the introduction of a uniform Federal Rules of Civil Procedure, while many state courts had done the same several decades earlier. ${ }^{95}$ The merger of law and equity represented a "triumph of equity," as the post-merger civil procedure derived mostly from equity procedure rather than common law procedure. ${ }^{96}$ The triumph of equity in procedure meant, effectively, that the merger allowed legal remedies to be enforced through equitable procedures. In the history of Equity Extraterritoriality, this is the moment at which the term "equity" in "Equity Extraterritoriality" becomes a historical marker rather than a descriptive term-because after the merger, courts may apply legal remedies extraterritorially by way of Equity Extraterritoriality.

The merger of law and equity served to amplify the internal contradiction in the application of territoriality principles to a new level. In 17 th century England, the inconsistency with which common law courts and the equity court approached the territoriality principle was manageable because common law and equity played separate and complementary roles: common law provided the general rules, and equity was an exception invoked only in extraordinary cases. Eliminating the separation between common law and equity meant that the principles that served to limit the application of equity to extraordinary cases would fall away. ${ }^{97}$ Accordingly, equity - which was once considered "[a] special doctrine reserved for special occasions"-became "ordinary, not extraordinary, in remedies, procedure, and substance." 98 As a result, "the merger of law and equity contributed to

95. See Price, supra note 24 , at 811 .

96. See Subrin, supra note 31, at 943.

97. See Weinstein, supra note 49 , at 171-72 (lacking of understanding as to the historical background of a legal doctrine leads to a "doctrinal incoherence").

98. Douglas Laycock, The Triumph of Equity, 56 LAW \& CONTEMP. ProBS. 53, 53-54 (1993). See 
a greater geographical coverage and type of activity affected than is seen in equitable decrees of earlier eras." 99

One of the main limiting principles of equity had been that equity acted only in cases of "irreparable injury," namely the types of injury for which there was no adequate remedy at law. But in a court lacking a formal distinction between law and equity, with a fading memory of what remedy was legal versus equitable, that limiting principle became a non sequitur. ${ }^{100}$ Another major limiting principle for equity had been that equity was confined to the protection of property rights. ${ }^{101}$ This is one of the reasons why the "classic" cases of Equity Extraterritoriality invariably involved a disposition of res of some kind. This limitation, too, essentially disappeared after the merger of law and equity. ${ }^{102}$ Even in equity cases that purportedly stayed within the "property rights" limitation, the concept of "property rights" was stretched far beyond a disposition of res. The creative expansion of "property rights" limitation in this time period would allow injunctions to govern strikes and labor disputes, ${ }^{103}$ shut down illegal saloons during Prohibition, ${ }^{104}$ and defeat racial segregation. ${ }^{105}$ As the court's power

also Willis L. M. Reese, Full Faith and Credit to Foreign Equity Decrees, 42 IowA L. REV. 183, 190-91 (1957) ("Equitable relief has now become so common that it can hardly be considered more extraordinary than relief at law.").

99. Price, supra note 24, at 812. See also Spelling, supra note 14, at 5-6 ("The range of purpose for which this remedial writ may be invoked is almost infinite.").

100. See Price, supra note 24, at 815-16; Douglas Laycock, The Death of the Irreparable Injury Rule, 103 HARV. L. REV. 687, 609, 692 (1990) (arguing that the original meaning of the "irreparable injury" requirement was that a party did not have remedy at law, and this original meaning disappeared).

101. See Frederick W. Stevens, Proper Use of the Writ of Injunction: From the Standpoint of Legal History, 8 COLUM. L. REV. 561, 566 (1908) ("Unless statutes have prescribed otherwise, injunctions issue only where the controversy concerns property, or property rights, including, of course, contract rights; and not always then.").

102. See Knighton v. Knighton, 41 So. 2d 172, 174 (1949) (holding that, in an alienation of affection case, "[i]t is now well settled here and elsewhere that injunctive relief is not limited to the protection of property rights, but extends to the protection of personal rights in many fields where no adequate remedy at law is available.") (quoting Henley v. Rockett, 8 So. 2d 852, 853 (Ala. 1943)); Everett v. Harron, 110 A.2d 383, 387 (1955) (holding in a racial desegregation case that the "property rights" limitation of equity is "a generalization more honored in the breach than the observance, and runs counter to the cardinal need of flexibility in the domain of equity jurisprudence.") (internal citation and quotation omitted).

103. See, e.g., Regal Knitwear Co. v. Nat'l Labor Rel. Bd., 324 U.S. 9, 9 (1945). See also Luke P. Norris, Labor and the Origin of Civil Procedure, 92 N.Y.U. L. Rev. 462, 482-90 (2017) (recounting the history of equitable injunctions against the labor movement).

104. Price, supra note 24, at 815 .

105. See GARY L. MCDOwell, EQuity AND the CONSTITUTION 97-110 (1982) (discussing the difference between equitable reliefs in school desegregation cases from the traditional equitable reliefs). See also Abram Chayes, The Role of the Judge in Public Law Litigation, 89 HARV. L. REV. 1281, 129296 (1976) (discussing the "the increasing importance of equitable relief" in issuing forward-looking equitable remedies to address social issues.). 
deriving from equity grew exponentially following the merger of law and equity, so did the court's authority to issue Equity Extraterritoriality orders.

\section{b. Personal Jurisdiction Revolution}

Also in the mid-20th century, the U.S. legal doctrine on personal jurisdiction would undergo a revolution, for the most part upending Pennoyer's personal jurisdiction doctrine. Legal realists led this revolution as a part of their broader attack against formalist assumptions in the law. ${ }^{106}$ The revolution's effect was an expansion of the court's judicial jurisdiction on the basis of "reasonableness," covering persons outside of the court's territorial jurisdiction. ${ }^{107}$ In other words, for the first time in U.S. constitutional history, the territoriality principle would be applied consistently in favor of extraterritoriality. This harmonization would be over by the late 20th century, when the Supreme Court began the retrenchment of personal jurisdiction. But this brief period of harmonization would create a synergy that propelled Equity Extraterritoriality even farther away from the court's territorial jurisdiction. In fact, much of the Equity Extraterritoriality doctrine's strength, as it stands today, derives from the jurisdictional theories of this time.

The expansion of personal jurisdiction came on two fronts: "minimum contacts" doctrine and the "effects" test. The Supreme Court announced the minimum contacts doctrine in International Shoe Co. v. Washington, ${ }^{108}$ a seminal case that restructured the territorial limitation on personal jurisdiction that Pennoyer imposed. The Supreme Court famously announced that a person no longer needed to be within a court's territorial jurisdiction to be subject to that court's judicial jurisdiction; instead, having "certain minimum contacts with it such that the maintenance of the suit does not offend traditional notions of fair play and substantial justice" would suffice. ${ }^{109}$ Accordingly, the Court found that a Delaware corporation with a principal place of business in Missouri was properly subject to the jurisdiction of a court in Washington, as the corporation's business activities with the state of Washington were "systematic and continuous." 110 The Supreme Court would later decide in Shaffer v. Heitner that the "minimum

106. See Lea Brilmayer, Conflict of Laws 35 (2d ed. 1995); Albert A. Ehrenzweig, A CounterRevolution in Conflicts Law? From Beale to Cavers, 80 HARV. L. REV. 377, 379 (1966).

107. See Austin Parrish, Sovereignty, Not Due Process: Personal Jurisdiction over Nonresident Alien Defendants, 41 WAKE FOREST L. REV. 1, 13-18 (2006) (describing the rise of reasonableness standard in the personal jurisdiction doctrine).

108. 326 U.S. 310,310 (1945).

109. Id. at 316 (citation omitted).

110. Id. at 320 . 
contacts" test would govern the assertion of in rem and quasi in rem jurisdiction, in addition to the assertion of in personam jurisdiction. ${ }^{111}$

The "effects" doctrine traces its genesis to United States v. Aluminum Co. of America (Alcoa), ${ }^{112}$ a decision by Judge Learned Hand announced on the same year as International Shoe. Alcoa represents a union of the contemporary international law and then-existing domestic law, not unlike the way Pennoyer was the union between Westphalian territoriality concept and traditional Anglo-American law. In 1927, the Permanent Court of International Justice decided the famous S.S. Lotus case, in which it established a presumption in favor of a nation's legislative jurisdiction, even over conduct occurring abroad. ${ }^{113}$ Meanwhile, since American Banana, the U.S. Supreme Court has issued a series of cases that chipped away at American Banana's territoriality doctrine. ${ }^{114}$ Drawing from these decisions, Judge Hand held in Alcoa that it was "settled law . . . that any state may impose liabilities, even upon persons not within its allegiance, for conduct outside borders that has consequences within its borders which the state reprehends." 115 The "effects" test in Alcoa had an additional element of intent; unless the party intended to direct the effect to the United States, there was no jurisdiction. Accordingly, the Sherman Act (the law sub judice in Alcoa) would not cover a trade between Europe and South America that incidentally affected the United States. ${ }^{116}$ The subsequent courts, however, gradually de-emphasized the intent requirement, requiring only that the effect be substantial and direct. ${ }^{117}$ According to Professor John Knox: "By the late 1960s, there was little or no reason for lower courts to believe that the presumption against extraterritoriality barred the application of federal law to connected actions within and without U.S. territory, or to foreign actions with substantial domestic effects."

111. 433 U.S. 186, 195, 207 (1977).

112. 148 F.2d 416, 443-45 (2d Cir. 1945). The Second Circuit decided Alcoa by virtue of a certificate from the Supreme Court, which did not have the quorum to decide the case. See id. at 421.

113. S.S. "Lotus" (Fr. v. Turk.), 1927 P.C.I.J. (ser. A) No. 10, at 16 (Sept. 7).

114. See United States v. Pacific \& Arctic Ry. \& Nav. Co., 228 U.S. 87, 105-6 (1913) (application of the Sherman Act to an antitrust scheme formed in Canada); Thomsen v. Cayser, 243 U.S. 66, 88 (1917) (application of Sherman Act on an antitrust scheme formed in South Africa); United States v. Bowman, 260 U.S. 94, 96-100 (1922) (applying criminal statute prohibiting fraud against a U.S. government-held corporation in a criminal scheme formed on the high seas); United States v. Sisal Sales Corp., 274 U.S. 268, 274-76 (1927) (application of the Sherman Act to an antitrust scheme formed in Mexico); see also Swaine, supra note 22 , at 641-42.

115. Alcoa, 148 F.2d at 443 .

116. See id.

117. See Swaine, supra note 22, at 642 .

118. John H. Knox, The Unpredictable Presumption Against Extraterritoriality, 40 Sw. L. REV. 635, 
It is beyond the scope of this paper to assess the wisdom of International Shoe's minimum contacts test or Alcoa's effects test; ${ }^{119}$ it is sufficient to say that these two doctrinal changes in personal jurisdiction greatly expanded the reach of Equity Extraterritoriality. The essence of Equity Extraterritoriality is two links of control: the court's control over a person, and the person's control over an extraterritorial thing or conduct. ${ }^{120}$ The personal jurisdiction revolution stretched the first link close to its breaking point. One must remember that, even as Pennoyer approved Equity Extraterritoriality, it placed an outer limit as to how far Equity Extraterritoriality could reach by way of its territorial jurisdiction doctrine. Under Pennoyer, the court could only assert jurisdiction over persons who were served with process within the court's territorial jurisdiction. ${ }^{121}$ Practically speaking, this meant that for the most part, the only way for the court to reach beyond its territorial jurisdiction via Equity Extraterritoriality was through the residents of the state in which the court was located. ${ }^{122}$ Stated differently, Pennoyer limits the court's extraterritorial reach in equity to the extraterritorial connections of residents or corporations within the court's territorial jurisdiction.

In this sense, the prohibition against extraterritorial jurisdiction in Pennoyer was one of the last limitations placed on the reach of Equity Extraterritoriality - because once jurisdiction was obtained, there was no longer any meaningful check on the distance that Equity Extraterritoriality might cover. The personal jurisdiction revolution rendered this last remaining limitation by Pennoyer close to meaningless. With the "minimum contacts" and "effects" tests combined, the court could (and can today) issue orders against foreign persons located anywhere in the world. ${ }^{123}$ For example: a federal court in New York can first find that it has judicial jurisdiction over a foreign party - say, from Argentina - that previously never set foot in the State of New York, based on the finding that the party has sufficient minimum contacts with New York. Then, pursuant to the well-

638 (2011).

119. For a discussion criticizing the International Shoe rule, see, e.g., George Rutherglen, International Shoe and the Legacy of Legal Realism, 2001 SuP. Cт. REV. 347, 347 (2001). For a discussion considering the merits of Alcoa, see Breyer, supra note 21, at 98-101.

120. See discussion supra Section II.B.

121. See Pennoyer v. Neff, 95 U.S. 714, 723-26 (1877).

122. An exception would be the relatively rare case of transient jurisdiction, i.e. a case in which a non-resident is served with process while being within the court's territorial jurisdiction. See Burnham v. Superior Ct. of Cal., 495 U.S. 604, 619 (1990).

123. See Austen Parrish, The Effects Test: Extraterritoriality's Fifth Business, 61 VAND. L. REV. 1455, 1478-79 (2008) (“The effects test thus gives license for near universal jurisdiction.”). 
established principle of Equity Extraterritoriality, the court may issue an extraterritorial provisional order against the foreign party, prohibiting the party from taking certain actions in Argentina that would frustrate the object of the litigation pending in New York. Further, the court can enjoin any third party from assisting the foreign party to violate the court's order, no matter where such person may be located in the world, based on the "effects" testin other words, by claiming that such person's actions would create an effect of frustrating the court's order. This example is not a fanciful imagination, but a close analogue of the actual events that transpired in the New York court case that attempted to enforce the sovereign debt of the Republic of Argentina. ${ }^{124}$ There, a federal court in New York not only enjoined the South American foreign sovereign, but also European financiers that were doing business with the foreign sovereign, based on the legal theories outlined above. $^{125}$

Pennoyer did approve Equity Extraterritoriality, which reached pretty far beyond the court's territorial jurisdiction. But ultimately, Equity Extraterritoriality under Pennoyer was orbiting around a central gravitational force: the strong territoriality principle, derived from the Westphalian principle of territorial sovereignty and the common law tradition. Once the rebel forces of the personal jurisdiction revolution destroyed that center of gravity, it had the effect of launching Equity Extraterritoriality beyond the orbit. Without any legal principle to tie it down, Equity Extraterritoriality would fly adrift.

C. Deepening Divide Between Common Law Extraterritoriality and Equity Extraterritoriality in Late $20^{\text {th }}$ Century

The mid-20th century saw a brief period of harmonization in the application of territoriality principles in favor of extraterritorial reach. This period of harmonization would end in the late 20th century, as the U.S. Supreme Court would issue a series of decisions that rejuvenated the strength of the presumption against extraterritoriality. But this retrenchment from extraterritoriality would occur only on the side of personal and legislative jurisdiction. Although the Supreme Court did sporadically address Equity Extraterritoriality in this time period, such efforts, taken together, did little

124. See discussion infra Sections IV.C.2 and IV.C.3. For general overview of the Argentina sovereign debt enforcement, see Andrew Pomager, Enjoining Foreign Conduct of Non-Parties: NML Capital Ltd. v. Republic of Argentina, 29 TEMP. INT'L \& COMP. L.J. 349, 350 (2015); Karen H. Cross, The Extraterritorial Reach of Sovereign Debt Enforcement, 12 BERKELEY BUS. L.J. 111, 126 (2015).

125. See Cross, supra note 124 , at 111. 
to pull back the reach of Equity Extraterritoriality. This resulted in the split attitudes in the application of U.S. territorial principles that we have today.

1. Jurisdictional Extraterritoriality Retrenches

The expansion of the U.S. court's extraterritorial jurisdiction, occasioned by International Shoe and Alcoa, began to reverse by late 20th century. In a series of decisions, the Supreme Court began curtailing the assertions of jurisdiction that arguably might have passed muster under International Shoe and/or Alcoa. ${ }^{126}$ This trend of retrenchment would accelerate in the 21 st century, during which the U.S. Supreme Court issued a flurry of decisions that would mark the new high point of the doctrine of presumption against extraterritoriality that was unseen since Pennoyer and American Banana. ${ }^{127}$

Kulko v. Superior Court of California, decided in 1978, marks the beginning of the retrenchment. ${ }^{128}$ In Kulko, a married couple residing in New York divorced pursuant to a separation agreement executed in New York. Thereafter, the wife moved to California and sought to modify the separation agreement before the court in California. The court in Kulko found that the California court had no jurisdiction over the husband in New York, explicitly rejecting the theory that the husband had minimum contacts with California or engaged in conduct that caused an effect in California. ${ }^{129}$ Since Kulko, the Supreme Court regularly decided cases that tended to cut against the assertion of jurisdiction beyond the territorial jurisdiction of the court. In World-Wide Volkswagen Corp. v. Woodson, the court found that an Oklahoma state court had no jurisdiction over a New York car retailer who lacked minimum contact with Oklahoma, although Oklahoma residents purchased cars from the New York retailer and allegedly suffered injury in Oklahoma. ${ }^{130}$ In Rush v. Savchuk, the court held that a Minnesota state court

126. See Patrick J. Borchers, The Death of the Constitutional Law of Personal Jurisdiction: From Pennoyer to Burnham and Back Again, 24 U.C. DAVIS L. REV. 19, 90 (1990) (noting that the Supreme Court has invalidated perfectly reasonable assertions of jurisdiction in a series of cases in the late 20th century).

127. See also Pamela K. Bookman, Litigation Isolationism, 67 STAN. L. REV. 1081, 1084 (2015) (noting the recent trend of U.S. courts using the combination of personal jurisdiction doctrine, forum non conveniens, presumption against extraterritoriality and abstention doctrines to avoid adjudicating transnational litigation).

128. 436 U.S. 84, 84 (1978). It must be noted that Hanson v. Denckla, 357 U.S. 235, 255 (1958), the first case since International Shoe and Alcoa that invalidated a state court's assertion of jurisdiction, pre-dates Kulko by 20 years. However, Kulko marks the moment where the Supreme Court began the steady tendency to undercut the reach of the judicial jurisdiction.

129. 436 U.S. at $92-98$.

130. 444 U.S. 286, 299 (1980). 
could not assert jurisdiction over a case that involved an auto accident in Indiana between two Indiana residents. Although one of the Indiana residents later moved to Minnesota and became a Minnesota resident, the court found that the Indiana defendant did not have sufficient minimum contacts with Minnesota. ${ }^{131}$ In Helicopteros Nacionales de Colombia $v$. Hall, the court found that a Texas court had no jurisdiction over litigation arising from a helicopter crash in Peru, which involved a helicopter provided by a Colombian corporation, notwithstanding the fact that the Colombian corporation contracted with a Texan company to provide the helicopter. ${ }^{132}$ In Asahi Metal Indus. Co. v. Superior Court of California, the plurality of the court found that a Taiwanese company is not subject to litigation in California simply by placing its products in the stream of commerce, although the Taiwanese company's product may have caused a fatal motorcycle accident in California. ${ }^{133}$ On the same theory, the court invalidated a New Jersey state court's claim of jurisdiction over a British manufacturer of machine tools that allegedly caused personal injury, in $J$. McIntyre Mach. Ltd. v. Nicastro. ${ }^{134}$ In addition, the 2014 case of Daimler $A G$ v. Bauman significantly curtailed the so-called "doing business" general jurisdiction over foreign corporations. ${ }^{135}$

Beginning with E.E.O.C. v. Arabian American Oil Co. (ARAMCO), the court also started to focus more specifically on the extraterritorial applicability of American statutory law. ${ }^{136}$ Thus, in ARAMCO, the Court announced that Title VII of the Civil Rights Act did not apply to the employment practices occurring outside of the United States, notwithstanding the fact that both the employer and the employee were American. ${ }^{137}$ Since ARAMCO, the Supreme Court has used the same logic to limit the extraterritorial applicability of the Federal Tort Claims Act, ${ }^{138}$ federal immigrant law, ${ }^{139}$ the Sherman Act, ${ }^{140}$ federal criminal firearms

131. 444 U.S. 320, 332 (1980).

132. 466 U.S. 408, 418 (1984).

133. 480 U.S. 102, 116 (1987).

134. 564 U.S. 873, 887 (2011).

135. 134 S. Ct. 746, 763 (2014)

136. 499 U.S. 244, 259 (1991).

137. Id. at 258 .

138. See Smith v. United States, 507 U.S. 197, 204 (1993) (holding that the Federal Tort Claims Act is not applicable to tortious conduct in Antarctica).

139. See Sale v. Haitian Ctrs. Council, Inc., 509 U.S. 155, 188 (1993) (holding that federal immigration law's prohibition against returning refugees to countries where they could face persecution is not applicable to Haitian refugees apprehended on the high seas).

140. See F. Hoffman-La Roche Ltd. v. Empagran S.A., 542 U.S. 155, 175 (2004) (holding that the Sherman Act did not provide a cause of action for a foreign injury caused by a foreign price-fixing 
law, ${ }^{141}$ and federal patent law. ${ }^{142}$ The culmination of this trend is the trio of cases decided in the 2010s: Morrison v. National Australian Bank Ltd., ${ }^{143}$ Kiobel v. Royal Dutch Petroleum Co.,${ }^{144}$ and RJR Nabisco, Inc. v. European Community, ${ }^{145}$ which respectively invalidated the extraterritorial application of the private right of action under Section 10(b) of the Securities and Exchange Act of 1934, Alien Tort Statute, and private right of action under Racketeer Influenced and Corrupt Organizations (RICO) Act. The typically incisive pronouncement by Justice Antonin Scalia in Morrison succinctly summarizes the court's newly energized disposition against extraterritoriality: "When a statute gives no clear indication of an extraterritorial application, it has none."146

\section{Equity Extraterritoriality Grows in Neglect}

Compared to the zeal that the Supreme Court has shown on jurisdictional extraterritoriality in the late 20th and the early 21 st century, the Court's attention to Equity Extraterritoriality in the same time period has been intermittent at best. The few cases that addressed Equity Extraterritoriality are inconsistent in their result, likely because the court never considered these cases to be dealing with the same, recurring problem of territoriality and sovereignty. As a result, lower federal courts and state courts to this day have never truly relinquished the virtually limitless extraterritorial reach that they gained in the development of Equity Extraterritoriality in the mid-20th century.

In Baker v. General Motors Corp., the case that confounded Justices Breyer and Kennedy, the Supreme Court sought to clarify the relationship between the Full Faith and Credit Clause and Equity Extraterritoriality. ${ }^{147}$ Baker involved a complicated chain of events and a creative use of an extraterritorial injunction that is typical of late 20th century Equity Extraterritoriality. Ronald Elwell, an engineering analyst, sued his former employer General Motors in Michigan. General Motors counterclaimed, and the two parties settled with the Michigan court's approval. As a part of the

\footnotetext{
scheme, although the scheme may have caused domestic injury as well).

141. See Small v. United States, 544 U.S. 385, 394 (2005) (holding that federal law's prohibition of felons' purchasing a gun does not apply when the felony conviction was from a Japanese court).

142. See Microsoft Corp. v. AT\&T Corp., 550 U.S. 437, 458-59 (2007) (holding that federal patent law is not applicable to software installation outside of the United States).

143. 561 U.S. 247,273 (2010).

144. 569 U.S. 108, 125 (2013).

145. 136 S.Ct. 2090, 2111 (2016).

146. Morrison, 561 U.S. at 255.

147. 522 U.S. 222, 241 (1998).
} 
settlement, Elwell and General Motors stipulated to an anti-suit injunction of sorts: a permanent injunction barring Elwell from testifying in any litigation involving General Motors. Meanwhile, brothers Kenneth and Steven Baker were suing General Motors in Missouri, claiming that a faulty General Motors vehicle killed their mother. The Baker brothers subpoenaed Elwell to testify in Missouri; the Missouri court allowed the testimony, overruling General Motors' objection that the Michigan court order, issued pursuant to the settlement between Elwell and General Motors, prohibited Elwell from testifying in Missouri.

The majority opinion by Justice Ruth Bader Ginsburg began its analysis by recounting the history of extraterritorial injunction obtained as a part of the final judgment. ${ }^{148}$ Classifying the injunction against Elwell as a judgment was important, because the Full Faith and Credit Clause applied only to judgments. ${ }^{149}$ Because the injunction against Elwell was a part of the Michigan court's final judgment, it could possibly fall within the ambit of Full Faith and Credit, requiring the Missouri court to recognize the Michigan court's order. ${ }^{150}$ In this instance, however, the Supreme Court found that the Full Faith and Credit Clause did not require the Missouri court to follow the Michigan court's injunction: "a Michigan court, cannot, by entering the injunction to which Elwell and GM stipulated, dictate to a court in another jurisdiction that evidence relevant in the Bakers' case - a controversy to which Michigan is foreign - shall be inadmissible." 151 This was because "the Michigan decree cannot determine evidentiary issues in a lawsuit brought by parties who were not subject to the jurisdiction of the Michigan court."152

One can say that Baker is the Supreme Court's most significant pullback on Equity Extraterritoriality in the late 20th century, but that would not be saying much. It is true that Baker's majority opinion holds within it a kernel that could have grown potentially into a more robust theory limiting the reach of Equity Extraterritoriality. Indeed, the concurring opinion by Justice Anthony Kennedy makes this very point. ${ }^{153}$ Justice Kennedy

148. See id. at 234.

149. See id. at 232 ("The Full Faith and Credit Clause does not compel a state to substitute the statutes of other states for its statutes dealing with a subject matter concerning which it is competent to legislate.") (internal quotation omitted).

150. See id. at 234 ("The Court has never placed equity decrees outside the full faith and credit domain.").

151. Id. at 239 .

152. Id.

153. See id. at 244 (Kennedy, J., concurring) ("Our decisions have been careful not to foreclose all effect for the types of injunctions the majority would place outside the ambit of full faith and credit. These authorities seem to be disregarded in today's holding."). 
observed that the formulation by Justice Ginsburg would limit extraterritorial court orders that are "purport[ing] to accomplish an official act within the

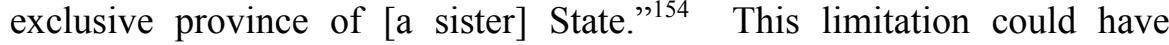
potentially grown into some type of limiting principle on the extraterritorial equitable orders that offend the plenary jurisdiction of another territorial sovereign. But this potential in Baker never materialized; the law today on Equity Extraterritoriality is the same as the day when Baker was announced nearly two decades ago. Further, even if Baker did realize its potential, it would have covered no more than a quarter of the issues that arise with Equity Extraterritoriality, as it only would address one-half of the extraterritoriality issues arising within the United States. That is to say: like Justice Holmes' suggestion in Fall, the hypothetical, fully-developed Baker doctrine would do nothing to extraterritorial court orders whose scope is international rather than interstate, operating in a world that lacks a sovereignty-harmonizing device like a Full Faith and Credit Clause. Even within the domestic setting, the hypothetical Baker doctrine would not address court orders that are not considered final judgments, since the Full Faith and Credit Clause only operates on final judgments. ${ }^{155}$

Grupo Mexicano de Desarrollo v. Alliance Bond Fund is another late 20th century case in which the Supreme Court could have limited the reach of Equity Extraterritoriality. ${ }^{156}$ Grupo Mexicano presented a classic Equity Extraterritoriality scenario, a disposition of res located outside of the court's jurisdiction. One slight difference, however-the lower court in Grupo Mexicano (i.e. the federal district court in New York) restrained the disposition of assets located in Mexico by way of a preliminary injunction prior to the final judgment, to enforce the obligation owed under a simple contract. This difference was sufficient for Justice Scalia to strike down this instance of Equity Extraterritoriality. Historically, English equity court lacked the authority to issue a pre-judgment injunction like this one; therefore, according to Justice Scalia, the contemporary U.S. courts likewise lacked the authority, unless there was a statute stating otherwise. ${ }^{157}$

154. Id. at 243 .

155. Thus, for example, the California Supreme Court decided Advanced Bionics Corp. v. Medtronic, Inc., 29 Cal. 4th 697, 700 (2002), a case involving an anti-suit preliminary injunction (as opposed to a final order) issued by a Minnesota court, without referring at all to the Full Faith and Credit Clause. The court, instead, made its decision "under principles of judicial restraint and comity." Id.

156. 527 U.S. 308, 319 (1999).

157. See id. at 318-33. 
Justice Ginsburg, in dissent, criticized this history-based approach, ${ }^{158}$ as did many learned commentators. ${ }^{159}$ For those concerned with the reach of Equity Extraterritoriality, however, Grupo Mexicano offered some hope. Like Justice Ginsburg's formulation in Baker, Justice Scalia's analysis of Grupo Mexicano provided a seedling of principle that, if fully grown, could perhaps govern Equity Extraterritoriality in general. We have seen earlier that although Equity Extraterritoriality existed in the equity courts of 17th century England, the equitable extraterritorial remedies at the time served a complementary role, dispensed only in extraordinary instances in which the more generally applicable common law did not provide an adequate remedy ${ }^{160}$ Applied consistently, Grupo Mexicano had the potential to grow into a more robust legal doctrine that regulated Equity Extraterritoriality, turning back the clock at least to the state of affairs that existed before the merger of law and equity. However, like Baker, Grupo Mexicano did not lead to a larger doctrine; it merely cut off one particular extension of Equity Extraterritoriality, leaving many other branches to continue growing.

At least part of the reason why Baker and Grupo Mexicano failed to grow into a larger doctrine may be that the Supreme Court did not see Equity Extraterritoriality as a standalone inquiry. This tendency is evident from the pair of Supreme Court cases involving extraterritorial discovery: Societe Nationale Industrielle Aerospatiale v. U.S. District Court ${ }^{161}$ and Republic of Argentina v. NML Capital, Ltd. ${ }^{162}$ Both cases show that the Supreme Court's respect for sovereignty decreases considerably when the sovereigntyoffending device is a discovery order-something that comes after the establishment of jurisdiction. One can discern that the Supreme Court did not recognize Equity Extraterritoriality as a standalone inquiry, because contrary to Baker and Grupo Mexicano, the Supreme Court extended the reach of Equity Extraterritoriality in Aerospatiale and NML Capital.

In Aerospatiale, the court engaged in a particularly strained interpretation of the Hague Evidence Convention to find that the Convention did not provide exclusive or mandatory procedures for obtaining documents

158. See id. (Ginsburg, J., dissenting) at 336 ("In my view, the Court relies on an unjustifiably static conception of equity jurisdiction. . . . Since our earliest cases, we have valued the adaptable character of federal equitable power.").

159. See, e.g., Richard H.W. Maloy, Expansive Equity Jurisprudence: A Court Divided, 40 SUFFOLK U. L. REV. 641, 645 (2007); David Capper, The Need for Mareva Injunctions Reconsidered, 73 FORDHAM L. REV. 2161, 2166 (2005); Stephen Burbank, The Bitter with the Sweet: Tradition, History, and Limitations of Federal Judicial Power-A Case Study, 75 NOTRE DAME L. REV. 1291, 1297 (2000).

160. See discussion supra at Section III.B.2.a.

161. 482 U.S. 522, 522 (1987).

162. 134 S.Ct. 2250,2250 (2014). 
and information located in the territory of a foreign signatory. ${ }^{163}$ In so finding, the court allowed the parties before a U.S. court to conduct discovery over material located outside of the United States pursuant to the Federal Rules of Civil Procedure, rather than through the Hague Evidence Convention. ${ }^{164}$ The court in Aerospatiale did caution that "American courts ... should exercise special vigilance to protect foreign litigants from the danger that unnecessary, or unduly burdensome, discovery may place them in a disadvantageous position." 165 Lower courts came to ignore this caution, routinely ordering a foreign person under their jurisdiction to produce materials located outside of the United States, even if a foreign law specifically prohibited such a production. ${ }^{166}$

In NML Capital, the Supreme Court found that the Foreign Sovereign Immunities Act (FSIA) did not prohibit post-judgment discovery of sovereign assets by way of subpoenas issued to third parties, no matter where the asset may be located. ${ }^{167}$ After finding that the FSIA completely preempted the common law on foreign state's sovereign immunity, the court found that discovery on sovereign assets was allowed because the FSIA was silent on the issue of post-judgment discovery. ${ }^{168}$ Argentina argued, to no avail, that such discovery would cover assets that could not be subject to execution under the FSIA, such as military weapons. The court dismissed the argument, noting that the party issuing the subpoena would not know what property Argentina had and whether such property was executable. ${ }^{169}$

From the perspective of territorial sovereignty, these two cases represent the apex of Equity Extraterritoriality - a total refusal to honor the sovereign interest of foreign states. Aerospatiale renders meaningless the Hague Evidence Convention, a multilateral treaty in which various sovereigns (including the U.S. executive) came together to agree on a procedure of gathering extraterritorial evidence in a way that minimizes the infringement upon their sovereignty. Aerospatiale further allows U.S. courts to ignore the foreign sovereign's explicitly stated policy preference, such as bank secrecy or data privacy. It seems difficult to imagine a way to ignore the concerns of foreign sovereignty more blatantly than Aerospatiale, but

163. For criticism of the Aerospatiale decision, see George A. Bermann, The Hague Evidence Convention in the Supreme Court: A Critique of the Aerospatiale Decision, 63 TUL. L. REV. 525, 525 (1989).

164. See Aerospatiale, 482 U.S. at 533.

165. Id. at 546.

166. See Sant, supra note 23, at 183-84.

167. See NML Capital, 134 S.Ct. at 2250.

168. See id. at 2256-58.

169. See id. at 2257. 
against all odds, the Supreme Court managed to find the way in $N M L$ Capital - under which U.S. courts can order a disclosure of property owned directly by the sovereign, no matter where the evidence for property or the property itself may be located, overruling the objections that the sovereign made directly to the court.

\section{Taking Stock of the U.S. Territoriality Doctrine Today}

Recent Supreme Court decisions and authoritative secondary materials firmly establish the validity of both jurisdictional presumption against extraterritoriality and Equity Extraterritoriality. In Baker, Justice Ginsburg explicitly endorsed Equity Extraterritoriality yet again, with no further attempt to apply territoriality principles to court orders. ${ }^{170}$ Restatement (Third) of the Foreign Relations Law of the United States cautions against extraterritorial assertion of jurisdiction, ${ }^{171}$ while Restatement (Second) of Conflict of Laws gives credence to Equity Extraterritoriality by attesting to the court's power to issue extraterritorial orders affecting persons and things beyond its territorial jurisdiction. ${ }^{172}$

Today, there are two broad categories of Equity Extraterritoriality. In the first category, which may be called "traditional" Equity Extraterritoriality, the court issues extraterritorial orders based on the authority derived from traditional equity practice. Examples of traditional Equity Extraterritoriality include discovery orders, ${ }^{173}$ post-judgment turnover orders, ${ }^{174}$ anti-suit injunction, ${ }^{175}$ and certain types of preliminary or permanent injunction that the court may fashion in response to the particular

170. See Baker, 522 U.S. at 235 (“a sister State's decree concerning land ownership in another State has been held ineffective to transfer title, although such a decree may indeed preclusively adjudicate the rights and obligations running between the parties to the foreign litigation.") (internal citations omitted, emphasis in original).

171. See, e.g., Restat. 3d Foreign Rel. § 421.

172. See, e.g., Restat. 2d Conflict of Laws $\S \S 53-55,65$.

173. See, e.g., Richmark Corp. v. Timber Falling Consultants, 959 F.2d 1468, 1482 (9th Cir. 1992) (contempt sanctions issued against a Chinese party for non-compliance with discovery order); Bank of Nova Scotia, 740 F.2d 817, 829 (11th Cir. 1984) (contempt sanction issued against a Cayman Island party for non-compliance with discovery order).

174. See, e.g., Rogers v. Webster, 1985 U.S. App. LEXIS 13968 (6th Cir. Oct. 22, 1985) (ordering delivery of stock certificates located in Canada to Michigan); In re Gaming Lottery Sec. Litig., 2001 U.S. Dist. LEXIS 1204 (S.D.N.Y. Feb. 13, 2001) (ordering delivery of bank accounts in Scotland to New York). Koehler v. Bank of Bermuda Ltd., 12 N.Y.3d 533, 541 (ordering delivery of stock certificates located in Bermuda to New York).

175. See, e.g., Allendale Mut. Ins. Co. v. Bull Data Sys., 10 F.3d 425, 433 (7th Cir. 1993) (enjoining a French party from bringing a claim in a French tribunal that had exclusive jurisdiction over the dispute under French law); Laker Airways Ltd. v. Sabena, Belgian World Airlines, 731 F.2d 909, 956 (D.C. Cir. 1984) (enjoining parties from seeking anti-suit injunction in Britain). 
circumstance of the case, pursuant to the court's inherent power derived from the equity tradition. ${ }^{176}$ The second category may be referred to as "statutory" Equity Extraterritoriality, in which the court issues extraterritorial orders to extend the reach of a statute or a regulation beyond the U.S. borders. The statute or regulation in question may or may not include an explicit authorization for extraterritorial application. For example, federal regulations governing embargoes against certain countries, ${ }^{177}$ or federal statutes designed to detect tax evasion by U.S. nationals residing abroad, ${ }^{178}$ explicitly authorize extraterritoriality. In many cases, however, the court issues extraterritorial orders pursuant to statutes that do not have any explicit authorization for extraterritorial application. ${ }^{179}$ In such a case, jurisdictional extraterritoriality and Equity Extraterritoriality work in tandem to stretch the authority of the statute beyond U.S. borders: jurisdictional extraterritoriality provides the court with the basis for extraterritorial prescriptive jurisdiction, and Equity Extraterritoriality with the basis for extraterritorial remedies. The U.S. Supreme Court has done this in Hartford Fire Insurance Co. $v$. California, when it applied the Sherman Act on the allegedly collusive scheme on British insurance companies, ${ }^{180}$ over Justice Scalia's vigorous dissent that Sherman Act's "boilerplate language" is an "insufficient indication to override the presumption against extraterritoriality." 181 Although Justice Scalia's insistence on the presumption against extraterritoriality eventually prevailed in the last decade, Hartford Fire remains standing as a valid precedent, flying in the face of Morrison's admonition that " $[\mathrm{w}]$ hen a statute gives no clear indication of an extraterritorial application, it has none."182

Numerous similar examples exist, in which courts have virtually ignored the presumption against extraterritoriality in statutory

176. See, e.g., Inst. of Cetacean Research v. Sea Shepherd Conservation Soc'y, 702 F.3d 573, 573 (9th Cir. 2012) (issuing preliminary injunction against physically attacking the vessels on the high seas); Ali v. Playgirl, Inc., 447 F.Supp. 723, 730 (S.D.N.Y. 1978) (issuing preliminary injunction prohibiting circulation of magazine cover with an unauthorized image of Muhammad Ali in Britain).

177. See, e.g., Cuban Assets Control Regulations, 31 C.F.R. 515.201(b) (1998) (prohibiting a foreign party from re-selling products from United States to Cuba).

178. See Foreign Account Tax Compliance Act, 26 U.S.C. $\$ \S 1471-74$ (2010) (requiring non-U.S. financial institutions to enter into an agreement with the Internal Revenue Service to identify their customers suspected of being persons subject to U.S. taxation).

179. See Parrish, supra note 123 at $1474-75$ ("if foreign conduct substantially affects the United States, then extraterritoriality is now often assumed.").

180. 509 U.S. 764, 799 (1993). For criticism of Hartford Fire's extraterritorial application, see Swaine, supra note 22 , at 678-84.

181. Hartford Fire, 509 U.S. at 814.

182. Morrison, 561 U.S. at 255. 
interpretation. ${ }^{183}$ Many bankruptcy courts have ruled that the automatic stay provided by the Bankruptcy Code applies extraterritorially, ${ }^{184}$ although the automatic stay provision in the Bankruptcy Code contains no authorization for extraterritorial application. ${ }^{185}$ Courts have justified this extraterritoriality by pointing to the Bankruptcy Code's regulatory aims. For example, Judge Richard Posner of the Seventh Circuit Court of Appeals found that the automatic stay provision applied to the debtor's assets located in the Caribbean because "[t]he efficacy of the bankruptcy proceeding depends on the court's ability to control and marshal the assets of the debtor wherever located" $" 186$-although the presumption against extraterritoriality announced in $A R A M C O$, and later again in Morrison, makes no reference to the need to maintain the efficacy of proceedings provided by a statute as a valid ground for the statute's extraterritorial application. More frequently, however, the court does not even give a flawed justification for extraterritorial application of a statute. In Wojnarowicz v. American Family Association, ${ }^{187}$ for example, a New York court enjoined the global distribution of a pamphlet that contained an unauthorized reproduction of the plaintiff's artwork pursuant to New York's Artists' Authorship Act, although the New York law has no reference to extraterritorial application. ${ }^{188}$ Although the terms of the injunction make clear that the injunction is to be applied beyond the territorial borders of the State of New York, ${ }^{189}$ the court did not address the issue of extraterritoriality at all.

183. See Parrish, supra note 123, at 1475-76 (discussing cases in which the effects test has "overpowered" the territoriality assumption).

184. See In re Rimsat, Ltd., 98 F.3d 956, 961 (7th Cir. 1996) (holding that bankruptcy court's in rem jurisdiction over estate property allows an international proceeding to be enjoined pursuant to the automatic stay); In re Likes Bros SS Co, Inc., 207 B.R. 282, 287 (Bankr. M.D. Fla. 1997) (holding that foreign creditor violated automatic stay in arresting Chapter 11 debtor's vessel in Belgium; U.S. bankruptcy court had exclusive jurisdiction over the vessel); In re Joseph Nakash, 190 B.R. 763, 771 (Bankr. S.D.N.Y. 1996) (holding that an Israeli official who commenced involuntary liquidation proceedings in Israel against a Chapter 11 debtor violated automatic stay); In re McLean Industries, 74 B.R. 589, 603 (Bankr. S.D.N.Y. 1987) (holding that creditor over whom bankruptcy court had personal jurisdiction violated automatic stay in seizing Chapter 11 debtor's vessel in Hong Kong); but see In re Maxwell Communications Corp., 170 B.R. 800, 818 (S.D.N.Y. 1994) (holding that avoidance under Bankruptcy Code $\S 547$ does not apply extraterritorially).

185. See 11 U.S.C. $\S 362$ (Bankruptcy Code section governing automatic stay).

186. Rimsat, 98 F.3d at 961 .

187. 745 F. Supp. 130, 149 (S.D.N.Y. 1990).

188. See N.Y. Art \& Cult. Affr. § 14.03 (McKinney 1990).

189. See Wojnarowicz, 745 F. Supp. at 148-49. 


\section{PROBLEM OF EQUITY EXTRATERRITORIALITY}

Having reviewed the history of Equity Extraterritoriality's doctrinal growth, this section offers an analysis of the problems caused by Equity Extraterritoriality. At its heart, the problem of Equity Extraterritoriality is the problem of extraterritoriality. Regardless of the U.S. law's Orwellian treatment that considers Equity Extraterritoriality to be "territorial," Equity Extraterritoriality as a practical matter causes the usual problems associated with extraterritorial application of a national law-including putting persons under conflicting legal obligations and straining diplomatic relations. The changes in modern commerce, which relies greatly on intangible property without a physical situs, are certain to amplify this problem of extraterritoriality. Without a guiding principle to rein in the excess of Equity Extraterritoriality, this pressure caused by increased use of Equity Extraterritoriality is bound to cause even greater problems, because the doctrine of Equity Extraterritoriality is far too under-developed to meet the new challenges posed by the contemporary economy.

\section{A. Measuring the Size of the Problem: the Case of Intangible Properties}

Whatever one's assessment of the doctrine may be, it cannot be denied that Equity Extraterritoriality has a sterling historical pedigree that potentially reaches as far back as medieval English law. ${ }^{190}$ Sometimes a doctrine's long history alone is enough to overcome the dubiety of the wisdom behind the doctrine. ${ }^{191}$ If Equity Extraterritoriality has been in operation in the Anglo-American legal tradition for centuries, why is it a problem now?

The historical trajectory of Equity Extraterritoriality provides some answers. In the pre-independence English law, it was possible to say that Equity Extraterritoriality was a gap-filling doctrine, deployed in small doses when the general rule under the common law and its restrictive territoriality doctrine caused an unfair result. ${ }^{192}$ This was arguably no longer true after Pennoyer, when the Supreme Court gave its imprimatur to Equity Extraterritoriality, and certainly not true after the mid-20th century when law and equity merged and equity-style orders became commonplace. With the advent of the modern regulatory state, and the looseness of the "effects" test of personal jurisdiction discussed above, the courts can potentially apply any statute beyond the territorial borders of the United States using Equity

190. See discussion supra Section III.A.

191. See, e.g., Burnham, 495 U.S. 604, 628 (1990).

192. See discussion supra Section III.B.2.a. 
Extraterritoriality. ${ }^{193}$ In other words, the history of Equity Extraterritoriality is one marked by the doctrine's increasing reach.

What, then, is in store for Equity Extraterritoriality in the 21st century? The changes in modern commerce indicate that parties will resort to Equity Extraterritoriality even more frequently, pushing the reach of the doctrine even further. Speaking of increasing global commerce may be a cliché, but the increase does incentivize the persons engaged in international commerce, as well as the national governments overseeing such persons, to reach beyond their borders. ${ }^{194}$ Reliance on Equity Extraterritoriality will only increase in this environment, in large part because it allows the extraterritorial reach that jurisdictional extraterritoriality prohibits. Beyond this general observation, however, one specific feature in the modern marketplace is expected to drive the growth of Equity Extraterritoriality: intangible properties.

\section{Rise of Intangible Properties}

Modern capitalism continuously generates more types of intangible properties of ever-greater dollar amount and ever-greater level of abstraction. The days when intangible properties were mostly debts, shares in a corporation, and simple forms of intellectual property, are firmly behind us as much as the days when horse and buggy was a common mode of transportation. Today's drive for efficient financing means that even tangible properties are converted into intangible properties, and simple intangible properties are converted into more complex and ethereal derivative products. A real estate investment trust (REIT), for example, is made up of interests in real properties or mortgages in real properties, and its shares are traded on major exchanges like shares of a mutual fund. ${ }^{195}$ Thus, REIT is essentially a device that converts real estate (as tangible a property as any property gets) into highly liquid securities (intangible property). For another example, in April 2014, Fantex Brokerage Services completed a \$4.2

193. See discussion supra Section III.B.2.b.

194. In the past forty years, the share of world trade in the global economic output has doubled, going from around 15 percent to more than 30 percent. In the same time period, America's imports have increased from 6.4 percent to 16.8 percent of the national GDP, and the exports from 6.7 percent to 13.5 percent. See World Bank, World DATABANK: WORLD DEVELOPMENT INDICATORS, available at http://databank.worldbank.org. See also Gunther Handl, Extra-territoriality and Transnational Legal Authority, BEyOnd TERritoriality: TRANSNATIONAL LEgal AUthority IN AN AgE OF GlobaliZATION 3 (Gunther Handl, Joachim Zekoll, Peer Zumbansen eds. 2012) ("a general consensus exists among experts that the single most significant trait of globalization is a fundamental change in the time and space dimensions of human existence.").

195. See generally RichaRd GARRIGAN \& JOHN PARSONS, REAL ESTATE INVESTMENT TRUSTS (1997). 
million initial public offering of Vernon Davis, then the tight end for the San Francisco 49ers of the National Football League. Fantex had previously paid Davis \$4 million for the right of 10 percent of Davis's future earnings, including the money earned through his NFL contract, endorsement, postcareer broadcasting deal, and so on. Fantex then converted the right in Davis's future earnings into shares, to be traded on its website. ${ }^{196}$ These new types of intangible properties, as well as the old types, may then be packaged into derivative products. A collateralized debt obligation (CDO), for example, packages a massive number of collateralized debts, typically a mortgage secured by a house, and divides them into several tranches of securities with different levels of risk and return. ${ }^{197}$ This packaging can be repeated multiple times, resulting in financial products called CDO-squared, CDO-cubed, and so on, to be sold in the financial market in a form that is radically different from the underlying assets. The net effect of this trend is the massive growth in the size and complexity of the intangible properties with murky obligor-obligee relationships - which came back to haunt the world in the 2008 financial crisis following the bankruptcy of Lehman Brothers, one of the largest brokers of intangible properties. ${ }^{198}$

The internet further complicated the issue of intangible properties. Much of the intangible properties are memorialized in the form of electronic data. (Indeed, much of the money in the bank in the world today is no more than an entry in the electronic books.) The data that makes up the intangible properties can be transferred near-instantaneously around the world. Focusing on this feature of the internet and intangible properties, some commentators in the early days of the internet argued that a significant portion of human wealth might be placed beyond the control of any country, whose authority was bounded by its territory. They predicted that the internet would become an autonomous province, unregulable by existing territorial sovereigns because "efforts to control the flow of electronic information across physical borders . . . are likely to prove futile, at least in

196. See ESPN, Vernon Davis Stock Hits $\$ 12$ in Debut, Apr. 28, 2014, http://espn.go.com/nfl/story/_id/10852827/vernon-davis-ipo-gains-20-percent-limited-debut.

197. See FINANCIAL CRISIS INQUIRY COMMISSION, THE FINANCIAL CRISIS INQUIRY REPORT: FINAL REPORT OF THE NATIONAL COMMISSION ON THE CAUSES OF THE FINANCIAL AND ECONOMIC CRISIS IN THE UNITED STATES 128 (2011).

198. To give a perspective: in just four years between 2003 and 2007, the U.S. financial industry generated nearly $\$ 700$ billion worth of just one type of intangible property, namely mortgage-backed securities. See id. at 129. Some of the issuers of CDO additionally issued liquidity puts on CDOs, creating too long of a chain of obligations for the bank to properly calculate the cost of risk in case of a contingency. See id. at 137-39. 
countries that hope to participate in global commerce." ${ }^{199}$ These predictions, of course, did not come to pass; as it turned out, these commentators severely underestimated the ability of Equity Extraterritoriality to control intangible properties.

2. Controlling Intangible Properties Through Equity Extraterritoriality

Traditionally, courts have dealt with intangible properties by engaging in a legal fiction: assigning them a situs, pretending that the intangible property is located at one place but not another. A seminal decision on situs is Harris v. Balk, in which the Supreme Court found that the situs of a debt was the location of the obligor. ${ }^{200}$ In the hundred years since Harris, courts have continued to designate a situs for each new type of intangible property that appeared. A copyright, for example, is located at the domicile of the owner of the copyright. ${ }^{201}$ Under New York's "separate entity rule," a bank account is located in the particular bank branch that holds the account and not elsewhere, even if the bank may have numerous branches throughout the world. ${ }^{202}$ Membership interest in a limited liability corporation is located on the person who holds the interest, and travels with the person even if the person crosses territorial boundaries. ${ }^{203}$ An Internet domain name is located at the registry where the domain name is registered, and not elsewhere. ${ }^{204}$

The function of the situs fiction is to bring the intangible property within the ambit of territorial jurisdiction. If a court's power is bounded by its territorial jurisdiction, these intangible properties must be made to have a territorial location for the court to be able to regulate them. ${ }^{205}$ The explosion of intangible properties in terms of their size, type, and complexity, makes the determination of situs - and ultimately, judicial control —of intangible properties resemble an exercise in absurdity and futility. This apparent

199. David R. Johnson \& David Post, Law and Borders - the Rise of Law in Cyberspace, 48 STAN. L. REV. 1367, 1372 (1996); see also WALTER B. Wriston, THE TWILIGHT OF SOVEREIGNTY: How thE INFORMATION REVOLUTION IS TRANSFORMING OUR WORLD (1992).

200. 198 U.S. 215 (1905); but see Aaron D. Simowitz, Siting Intangibles, 48 N.Y.U. J. INT’L L. \& POL. 259, 280-81 (2015) (arguing Harris stands for the proposition that intangible properties have no situs at all).

201. See, e.g., Pablo Star Ltd. v. Welsh Gov’t, 2016 U.S. Dist. LEXIS 33846, at*18 (S.D.N.Y. Mar. 16, 2016).

202. See, e.g., Global Tech., Inc. v. Royal Bank of Can., 943 N.Y.S.2d 791, 791 (N.Y. Sup. Ct. 2012).

203. See, e.g., Hotel 71 Mezz Lender LLC v. Falor, 14 N.Y.3d 303, 315-16 (N.Y. Ct. App. 2010).

204. See, e.g., Mattel, Inc. v. Barbie-Club.com, 310 F.3d 293, 306 (2d Cir. 2002).

205. In this sense, the situs fiction is not unlike the 17 th century common law courts' insistence that a foreign city was really in London. 
inability to determine the situs of intangible properties was the basis for the futuristic predictions of the internet beyond government regulations. ${ }^{206}$ But these predictions were wrong, because they ignored the central feature of intangible properties: their dependence on humans, who are subject to territorial authority. As it turned out, the territorial state did not really need to enforce the situs rules to regulate intangible property. To control an intangible property, the state only has to control the person within its territorial borders who controls the property. ${ }^{207}$ Regulatory authorities around the world have recognized this truth and responded accordingly. In 2014, the Korea Fair Trade Commission (KFTC) launched an investigation into the anti-competitive effect of Microsoft's acquisition of Nokia's smartphone division. Based on KFTC's conclusion that Microsoft's acquisition of Nokia's patent portfolio would likely restrain competition, KFTC and Microsoft ultimately entered into a consent decree whereby Microsoft committed to license its patents in a non-discriminatory manner. ${ }^{208}$ It hardly mattered to KFTC that most of Microsoft's patents - an intangible property -were "located" outside Korea, as Korean patents were less than five percent of Microsoft's patent portfolio. ${ }^{209}$ KFTC was able to control the disposition of Microsoft's non-Korean patents simply by controlling Microsoft's presence in Korea. ${ }^{210}$

The rise of intangible property, and states' subsequent response, have significant implications for Equity Extraterritoriality. Recall that the regulation of intangible properties through two links of controlscontrolling the person who controls the property-is precisely how Equity Extraterritoriality works. ${ }^{211}$ In Equity Extraterritoriality, the court controls a person through exercise of jurisdiction, and the court orders the person to take an extraterritorial action, often with respect to property located outside

206. See Johnson \& Post, supra note 198, at 1371-72 (using the example of intellectual property to discuss the predicted changes in private property interest).

207. See Paul B. Stephan, Courts on Courts: Contracting for Engagement and Indifference in International Judicial Encounters, 100 VA. L. REV. 17, 57 (2014) ("Even electronic events have a location, because the person who commands such events exists somewhere."); Goldsmith, supra note 48, at 476 ("The Internet is not, as many suggest, a separate place removed from our world. . . . Territorial sovereignty supports national regulation of persons within the territory who use the Internet.").

208. See John A. Jurata \& Inessa M. Owens, A New Trade War: Applying Domestic Antitrust Laws to Foreign Patents, 22 GEO. MASON L. REV. 1127, 1139-43 (2015).

209. See id. at 1141 note 83.

210. For general discussion on how one regulatory state may regulate beyond its borders by dint of the size of its market and other considerations, see Anu Bradford, The Brussels Effect, 107 Nw. U.L. Rev. 1,10 (2012).

211. See discussion supra Section II.B. 
of the court's territorial jurisdiction-which is, in the case of intangible properties, nowhere. Two specific implications are notable.

First, resorting to Equity Extraterritoriality to control intangible properties effectively discards the situs fiction. There are many good reasons to abandon the situs fiction, an "intellectual disaster" rife with conflicting legal theories that are ill-suited for the modern market. ${ }^{212}$ But the situs fiction does serve one useful function: applying the territoriality principles upon intangible properties. In an ideal world, the situs fiction would be replaced by a global regime that harmonizes the plenary jurisdiction over intangible properties. In our less-than-ideal world with no such regime, ${ }^{213}$ discarding the situs fiction and relying instead on Equity Extraterritoriality to regulate intangible properties invites clashes with foreign sovereigns, because the ethereal nature of intangible properties allows multiple states to make plausible claims of plenary jurisdiction over them. ${ }^{214}$ Today, in the case of most intangible properties that have more than de minimis value, the purchase, sale, creation and use of those intangible properties occur in multiple countries. The following hypothetical situation is typical: a U.S. video game company and a Japanese video game company jointly create an augmented-reality game that collects the player's location data, and sells the game in Australia. ${ }^{215}$ The Australian videogame player's every movement (tracked by player's GPS navigation system embedded in her smartphone) is stored in the data center located in Canada. Depending on the particularities

212. Simowitz, supra note 200, at 270, 284-292.

213. Arguably, one subset of intangible properties - intellectual property — is subject to such a global regime, based on the numerous international treaties on intellectual property. See World Intellectual Property Organization, WIPO-Administered Treaties, at http://www.wipo.int/treaties/en/. But the example with Microsoft and KFTC indicates the weakness of this regime to a state governing the intellectual property "located" beyond its territorial jurisdiction by controlling the party who controls such intellectual property. In addition, the virtually limitless nature of Equity Extraterritoriality means the U.S. court may even override the executive branch's decision to entire into such treaties. See, e.g., Aerospatiale, 482 U.S. 522, 522 (1987) (finding that the Hague Evidence Convention is not the exclusive means of conducting discovery abroad, effectively allowing extraterritorial discovery through ordinary civil procedure). See also discussion supra Section III.C.2.

214. I do not consider multiple claims of plenary jurisdiction per se to be a problem. Rather, the problem arises from the fact that it is a single district court, rather than the political branches, that is making the claim of plenary jurisdiction. See further discussion infra at Section IV.2. Professor Aaron Simowitz, who advocates for discarding the situs fiction, anticipates this issue and proposes a similar solution for intangible properties as I do for Equity Extraterritoriality — namely, a conflict of laws-based approach. See Simowitz, supra note 200, at 292-323.

215. This example is loosely based on Pokémon GO, an augmented-reality game that is considered one of the most successful mobile apps of all time. See Sarah Perez, Pokémon Go Installed on More Devices than Candy Crush, LinkedIn, Lyft, Tinder \& More, TECHCRUNCH, July 14, 2016, https://techcrunch.com/2016/07/14/pokemon-go-installed-on-more-devices-than-candy-crush-linkedinlyft-tinder-more/. 
of a potential legal claim, any two or more of Australia, Canada, Japan and the United States can plausibly assert plenary jurisdiction over the intangible property in this scenario - namely, data created by the physical movements of Australian gamers. If a U.S. court does seek to control this data, it is likely to rely on Equity Extraterritoriality, since it has personal jurisdiction over the U.S. Company that has the ability to control the data's disposition. For example, a U.S. court may issue a subpoena compelling the U.S. Company to produce the location data of a certain Australian individual who plays the game. Unless the Equity Extraterritoriality doctrine is modified to accommodate the interests of foreign sovereigns - in this case, interest of the Australian government to protect the privacy of its citizens' movement data, the interest of the Canadian government to manage the data that is housed within its territorial jurisdiction, and the interest of the Japanese government to regulate a company incorporated and doing business within its territorythe regulation of intangible properties is likely to become a free-for-all endeavor in which "economic might is right." 216

Second, regulating intangible properties through Equity Extraterritoriality does not only direct the court's authority to the ultimate owner of the intangible property, but also to the property's entire chain of custody. To a much greater degree than tangible properties, intangible properties rely on intermediary custodians. (You can own and keep a gold bar under your physical possession, but you cannot own a bank account without a bank.) In the many instances in which the owner of intangible property is not amenable to the court's jurisdiction, the court will simply assert jurisdiction over the intermediary that is within the court's jurisdiction to control the disposition of the intangible property. In addition, as discussed earlier, the court will also assert jurisdiction over any intermediary that may potentially interfere with its orders, even if the intermediary has no other contact with the forum. ${ }^{217}$

Such exercise of Equity Extraterritoriality applied to third parties can very quickly become abusive. Simply being haled to court incurs cost on third parties. They have no stake in the lawsuit, but they must appear lest they should become subject to double liability. ${ }^{218}$ As discussed above, third parties who would be ordinarily beyond the court's jurisdiction are haled to

216. J.S. Stanford, The Application of the Sherman Act to Conduct Outside of the United States: A View from Abroad, 11 CORNELL INT'L L.J. 195, 213 n.46 (1978) (quoting a Canadian governmental official protesting the application of U.S. antitrust laws on Canadian corporations).

217. See discussion supra Sections II.A., III.B.2.b.

218. See discussion infra Section IV.B.3. 
the court based on the most tenuous claim of jurisdiction. ${ }^{219}$ In the Argentina sovereign debt case, the Southern District of New York did not simply prohibit Argentina from paying one group of creditors versus another; the court also specifically enjoined a number of intermediaries who serviced Argentina's bond payments, including Euroclear S.A./N.V. of Belgium and Clearstream Banking S.A. of Germany and Luxembourg. ${ }^{220}$ These intermediaries were located in Europe, and had no contact with New York in relation to the Argentina case except indirectly through their relationship with the Republic of Argentina. ${ }^{221}$ The New York court's sole basis of giving this order to the European intermediaries was that they might interfere with the court's own extraterritorial order. The Second Circuit's reaction to this bootstrapping claim of jurisdiction was a dismissive hand-wave: "By naming certain foreign payment system participants . . . the district court was, again, simply recognizing the automatic operation of Rule 65 [of the Federal Rules of Civil Procedure]."222 Although the district court issued an order that, in all practicality, governed parties outside of New York and regulated their conducts occurring entirely outside of the court's territorial jurisdiction, the Second Circuit did not consider the issuance of the order to be an exercise of jurisdiction: "the amended injunctions enjoin no one but Argentina ... If others in active concert or participation with Argentina are outside the jurisdiction or reach of the district court, they may assert as much if and when they are summoned to that court.",223

To return to this section's initial question: if Equity Extraterritoriality has been in operation in the Anglo-American tradition for centuries, why is this a problem now? One answer is that the use of intangible property will only increase in the coming decades of globalized commerce, which will likely lead to greater reliance on Equity Extraterritoriality. Through Equity Extraterritoriality, the courts will reach even farther beyond their territorial jurisdiction, to adjudicate upon property of astronomical value and persons

219. See discussion supra Section III.B.2.b., infra Section IV.C.3.

220. See NML Capital Ltd. v. Republic of Argentina, No. 08 Civ. 6978 (TPG) (S.D.N.Y. Nov. 21, 2012), aff'd, 727 F.3d 230, 244 (2d Cir. 2013), cert. denied, 134 S. Ct. 2819, 2819 (2014).

221. See Brief for Non-Party Intervenors Euro Bondholders at 16-20, NML Capital Ltd. v. Republic of Argentina (2d Cir. Jan. 4, 2013), No. 12-105, Dkt. No. 702.

222. NML Capital Ltd. v. Republic of Argentina, 727 F.3d 230, 244 (2d Cir. 2013).

223. Id. In an Equity Extraterritoriality case following NML Capital, the Second Circuit made an extremely fine distinction - one that cannot be sustained in my view - that while issuing an order against extraterritorial third parties does have the effect of compelling them to act, but is not an exercise of jurisdiction. See Gucci Am. v. Bank of China, 768 F.3d 122, 129-130 (2d Cir. 2014) ("Granted, once a district court issues a preliminary asset freeze order enjoining parties over whom it has jurisdiction, that injunction automatically forbids others ... But such injunctions do not directly restrain the conduct of nonparties."). 
who are not even parties to the litigation. This is the scale of the problems of Equity Extraterritoriality that we may expect to face, based on the anticipated growth and spread of intangible property.

The future of global commerce will expose the flaws of Equity Extraterritoriality even more and make them worse. What, then, are the flaws of Equity Extraterritoriality? The doctrinal problems of Equity Extraterritoriality may be divided into two broad categories: (1) problem of extraterritoriality, namely the problems arising from the extraterritorial application of U.S. laws, and; (2) problem of under-development, i.e. the problems arising from the fact that there are very few limitations on the reach of Equity Extraterritoriality. The paper examines each category in turn.

\section{B. First Problem of Equity Extraterritoriality: Problem of Extra- territoriality}

By allowing U.S. courts to reach beyond U.S. borders, Equity Extraterritoriality causes problems usually associated with extraterritoriality, which may be categorized into three interrelated types: (1) interference with the interest of a foreign sovereign; (2) strife in diplomatic relations; and (3) conflicting legal obligations.

1. Interference with Foreign Sovereign Interest

Equity Extraterritoriality may infringe upon the interests of a foreign sovereign proper. U.S. courts regularly issue extraterritorial orders directly against foreign sovereigns. The Argentina bond litigation, of course, is the famous example. ${ }^{224}$ In another recent example, the federal court for the District of Maryland issued an anti-suit injunction directly against the Republic of Korea, prohibiting it from pursuing litigation in the Korean courts against a U.S. defense contractor regarding a contract to upgrade Korea's F-16 fighter jets. ${ }^{225}$ When foreign sovereigns refuse to comply with a U.S. court's Equity Extraterritoriality orders, the courts have held the foreign sovereigns in contempt. The federal court for the District of Columbia, for example, held the Russian government in contempt for failing to return religious books and artifacts, located in Russia, to a Jewish religious organization in New York. ${ }^{226}$

224. See NML Capital, 699 F.3d at 254-55.

225. See BAE Sys. Tech. Solution \& Servs. v. Republic of Korea's Def. Acquisition Program Admin., 2016 U.S. Dist. LEXIS 94028 (D. Md. July 19, 2016).

226. See Agudas Chasidei Chabad of United States v. Russian Fed'n, 915 F.Supp. 2d 148, 155 (D. D.C. 2013). See also FG Hemisphere Assocs. v. Dem. Republic of Congo, 637 F.3d 373, 380 (D.C. Cir. 2011) (holding Congo in contempt for failing to cooperate in post-judgment asset discovery); Autotech Techs. LP v. Integral Research \& Dev. Corp., 499 F.3d 737, 752 (7th Cir. 2007) (finding the district court 
More commonly, Equity Extraterritoriality infringes upon a foreign sovereign's regulatory or adjudicatory interests. A foreign sovereign, for example, may have an interest in protecting data and information originating from its territory. There is a significant amount of governmental interest in prescribing the extent to which sensitive personal data, such as medical or financial information, becomes available to third parties. Accordingly, a number of countries passed laws concerning bank secrecy and data privacy. 227 Some countries passed "blocking statutes" specifically to express their disapproval of the U.S.-style extraterritorial discovery. ${ }^{228}$ Yet the U.S. law on extraterritorial discovery does not merely disregard the foreign law regarding bank secrecy or data privacy, but overrules them as illegitimate. ${ }^{229}$ In doing so, the U.S. law all but made a dead letter out of a multilateral Hague Evidence Convention that the United States bargained for and signed-a "truly unprecedented attack on the basic mechanism of international treaties." 230 Another example is anti-suit injunctions issued by a U.S. court, which deprive the jurisdiction of a foreign court over the same matter, and sometimes lead to "inter-jurisdictional judicial warfare.",231

\section{Strife in Diplomatic Relations}

Because Equity Extraterritoriality infringes upon a foreign sovereign's interest, it frequently causes diplomatic strife. The Argentina bond case, litigated before a New York federal court, provided anti-American fodder to Argentina's politicians. ${ }^{232}$ Reporters for the Restatement have noted the level of friction and acrimony caused by extraterritorial discovery orders. ${ }^{233}$

had jurisdiction to issue a contempt judgment against an instrumentality of the government of Belarus while overturning the contempt judgment on the merits).

227. See Restatement (ThiRd) OF the Foreign Relations LaW of THE U.S., § 442, n.1 (Am. Law Inst. 1987); Christopher Kuner, EuROPEAN DATA PRIVACY LAW AND ONLINE BuSINESS $\S \S 3.12$ 3.36 (2d ed. 2007).

228. See Mark A. Cotter, The Hague Convention: Selfish U.S. Interpretation Aggravates Foreign Signatories and Mandates Changes to Federal Discovery Rules, 6 FLA. J. INT'L L. 233, 243 (1991).

229. See Sant, supra note 23, at 213-19.

230. Bermann, supra note 162, at 545.

231. George A. Bermann, The Use of Anti-Suit Injunctions in International Litigation, 28 COLUM. J. TRAnSNAT'L L. 589, 631 (1990). See also George A. Bermann, Parallel Litigation: Is Convergence Possible?, 13 Y.B. Pvt. Int'1 L. 21, 29 (2011) ("The fact that anti-suit injunctions are addressed to private parties, and never to foreign courts themselves, does not minimize either their impact . . or their potential offensiveness to foreign States.").

232. See, e.g., Steven M. Davidoff, In Court Battle, a Game of International Brinksmanship with Argentina, N.Y. TIMES, Nov. 28, 2012, at B11.

233. RESTATEMENT (THIRD) OF THE Foreign RELATIONS LAW OF THE U.S., § 442, n.1 (Am. Law Inst. 1987) ("No aspect of the extension of the American legal system beyond the territorial frontier of the United States has given rise to so much friction as the requests for documents in investigation and litigation in the United States."). 
Extraterritorial orders issued pursuant to U.S. antitrust laws have "provoked the loudest and most consistent foreign protests." ${ }^{\text {234 }}$ Discussing American antitrust laws, a Canadian government official did not mince words: "For one government to seek to resolve the conflict in its favor by invoking its national law before its domestic tribunals is not the rule of law but an application, in judicial guise, of the principle that economic might is right." "235 Foreign governments would file amicus curie briefs objecting to U.S. extraterritoriality, but the U.S. court's deference to such views is not consistent. The In re Uranium Antitrust Litigation opinion is an example of hostility, in which the Seventh Circuit called the governments of Australia, Canada, South Africa, and the United Kingdom "surrogates" of the foreign corporation defendants who "subversively presented for them their case.",236 The Uranium court's hostility toward the foreign states prompted the State Department to inform the court that the opinion "has caused serious embarrassment to the United States in its relations with some of our closest allies." 237

It is a significant problem that the unelected judiciary, which is often a state court or a federal court applying state law, is effecting foreign policy consequences. When a court issues an extraterritorial order, it is conducting an indirect type of diplomacy against its constitutional mandate. ${ }^{238}$ The problem is worse when a state law is involved. Territoriality principles prohibit a state law from being applied beyond state borders, much less beyond U.S. borders. ${ }^{239}$ Yet under Equity Extraterritoriality, a state law may

234. William S. Dodge, Understanding the Presumption Against Extraterritoriality, 16 BERKELEY J. INT'L L.85, 122 (1998).

235. Stanford, supra note 214 , at 213 n. 46 .

236. 617 F.2d 1248, 1256 (7th Cir. 1980). In many cases including this one, the extraterritoriality dispute in antitrust is framed as a dispute over jurisdictional extraterritoriality rather than Equity Extraterritoriality. But in case of "statutory" Equity Extraterritoriality, the question of jurisdictional extraterritoriality inevitably leads to the question of Equity Extraterritoriality, because once the court obtains jurisdiction, it is virtually certain that it will issue an extraterritorial order, should the court find liability. See discussion supra Section III.D.

237. Letter from Legal Advisor Roberts Owen to Assistant Attorney General John H. Shenefield dated Mar. 17, 1980, reprinted in part in Marian L. Nash, U.S. Practice, 74 AM. J. INT'L L. 657, 665-67 (1980).

238. See Steven A. Kadish, Comity and the International Application of the Sherman Act: Encouraging the Courts to Enter the Political Arena, 4 Nw. J. INT’L L. \& BuS. 130, 134-39 (1982) (criticizing the potential entanglement with the U.S. courts with international politics through extraterritorial application of U.S. antitrust laws).

239. See, e.g., Japan Line Ltd. v. County of Los Angeles, 441 U.S. 434, 448 (1979) (striking down local taxes on shipping containers because foreign commerce is "preeminently a matter of national concern.”); Goldstein v. California, 412 U.S. 546, 556 (1973) (holding a state's copyright power ended at its borders). 
be applied anywhere in the world, causing diplomatic strife with foreign sovereigns.

\section{Creation of Conflicting Legal Obligations}

A different type of problem involving Equity Extraterritoriality is where there is a breakdown in one of the two links of control through which the doctrine operates - the court's control over the person, and the control of the person ordered over the extraterritorial action or properties. ${ }^{240}$ This problem is different from the two problems identified above in that it is not a state-tostate issue, but an issue facing the person appearing before the U.S. court. The court may order a person to take certain extraterritorial action, but the person's ability to execute the action may be compromised - which causes a problem, as the person becomes unable to carry out the court's order. One of the ways in which the person's control over extraterritorial action or property may be compromised is the presence of a foreign legal obligation; that is to say, the extraterritorial action to be accomplished, or the extraterritorial property to be disposed of, may be subject to competing legal obligations or conflicting foreign regulations. In these cases, the person must make an in terrorem choice between disobeying the U.S. court and violating foreign law or obligation.

U.S. courts can be quite cavalier about this dilemma. Courts of New York have developed a "strong and perhaps surprising"241 tradition of summarily dismissing claims of double liability by banks, curtly finding that "[i]f the Bank cannot, as it were, serve two masters and comply with the lawful requirements both of the United States and [a foreign country], perhaps it should surrender to one sovereign or the other the privileges received therefrom." ${ }^{242}$ U.S. courts routinely order foreign parties who are subject to foreign bank secrecy or data privacy law to break that law, so that the opposing party may conduct discovery over evidence located abroad. ${ }^{243}$

240. See discussion supra Section II.B.

241. Simowitz, Siting Intangibles, supra note 199, at 308 n.180 (parenthesis omitted).

242. First Nat'l City Bank, 271 F.2d 616, 620; See also Motorola Credit Corp. v. Uzan, 978 F. Supp. 2d 205, 210 (S.D.N.Y. 2013) ("it is well established that banks assume the risk of double liability as an ordinary cost of doing business in multiple jurisdictions.").

243. See, e.g., AstraZeneca LP v. Breath Ltd., 2011 U.S. Dist. LEXIS 42405 (D.N.J. Mar. 31, 2011) (ordering the plaintiff to produce documents protected by Sweden's Trade Secret Protection Act); Gucci Am., Inc. v. Curveal Fashion, 2010 U.S. Dist. LEXIS 20834 (S.D.N.Y. Mar. 8, 2010) (ordering a bank to produce Malaysian bank records in violation of Malaysian bank secrecy laws); Reino de Espana v. Am. Bureau of Shipping, 2006 U.S. Dist. LEXIS 54112 (S.D.N.Y. Aug. 4, 2006) (ordering a party to produce records from a criminal proceeding in Spain in violation of Spain's Law of Criminal Procedure). See also Sant, supra note 23, at 181 (noting "court-ordered law breaking" as to discovery "has increased at an exponential rate," as sixty percent of all court orders ordering violation of foreign laws have occurred 
In many cases, it is the exercise of Equity Extraterritoriality that compounds the problem of conflicting legal obligations. For example, foreign governments have responded against extraterritorial discovery orders and antitrust injunctions by passing blocking statutes. ${ }^{244}$ These blocking statutes create conflicting legal obligations for foreign or multinational partieswhich, again, the U.S. courts frequently ignore. ${ }^{245}$

\section{Second Problem of Equity Extraterritoriality: Problem of Under- Development}

The second problem associated with Equity Extraterritoriality is that of under-development. Extraterritorial application of U.S. law per se is not the only issue; after all, there are many situations in which a U.S. court's extraterritorial reach may be warranted. ${ }^{246}$ After all, the core intuition behind Equity Extraterritoriality is defensible under the traditional principles of territoriality: the court is merely exercising its power over persons and properties found within its territorial jurisdiction. Problems of extraterritoriality arise when the court begins to over-stretch this core intuition to a point that it interferes with another state's power over that state's territorial jurisdiction. Theoretically, when the court does reach extraterritorially, it is supposed to exercise discretion and modulate the reach of its orders. It is received wisdom that "if the requested decree would interfere seriously in some way with the sovereignty of another state, the injunction should be denied." 247 But because Equity Extraterritoriality as a doctrine is so severely underdeveloped, this admonition lacks the legal structure to rigorously rein in the excess of Equity Extraterritoriality.

Specifically, Equity Extraterritoriality's underdevelopment leads to four major issues: (1) practical over-extension of Equity Extraterritoriality; (2) inconsistency in the application of territoriality principles; (3) fostering inconsistency in jurisdictional territoriality, and; (4) transnationality blindness.

between 2010 and 2015).

244. See Cotter, supra note 228, at 243; Joseph P. Griffin, Foreign Governmental Reactions to U.S. Assertions of Extraterritorial Jurisdiction, 6 GEO. MASON. L. REV. 505, 505 n. 3 (1998); Carl A. Circa, Jr., The Challenge of Foreign Laws to Block American Antitrust Actions, 18 STAN. J. INT'L L. 247, 247 (1982).

245. See Sant, supra note 23, at 213-19.

246. For example, a U.S. court must be able to enforce a trade embargo against an enemy state, regardless of the fact that doing so may require the court to reach beyond its territorial jurisdiction. See discussion infra Section V.A.2.c.

247. Wright and Miller, 11A FED. PRAC. \& PROC. CIV. § 2945. 
1. Practical Over-Extension of Equity Extraterritoriality

Earlier, we noted how Equity Extraterritoriality leads to problems when the control of the person ordered by the court over the extraterritorial action or property is compromised. As discussed earlier, one of the ways in which such control is compromised is when there is a competing legal obligation. ${ }^{248}$ Another way in which the control may be compromised-and cause problems with Equity Extraterritoriality - is when the person ordered by the court lacks practical control. This often occurs with intangible properties whose existence, as noted earlier, depends greatly on third party intermediaries who act as custodians of the intangible properties. ${ }^{249}$ These third parties may have constructive control over the intangible properties, but not necessarily practical control. When a third party becomes subject to Equity Extraterritoriality in such a situation, the harm is felt far beyond the third party itself, and threatens the stability of the whole system that manages the existence of the intangible property.

This happened in the notorious Winter Storm Shipping Ltd. v. TPI, in which the Second Circuit considered whether electronic fund transfers (EFTs) passing momentarily through New York were attachable property under Rule B of the Supplemental Rules for Admiralty and Maritime Claims. $^{250}$ An EFT, the intangible property at issue in Winter Storm, typically involves an intermediary bank, especially when the EFT crosses the national border. In most cases, the intermediary bank processes the EFT in several hours. The Second Circuit ruled that, because the funds were located in New York in that small window of time, they were attachable by serving a restraining notice to the intermediary bank located in New Yorkregardless of the fact that both the sender and the recipient of the EFT might be outside of New York. In doing so, the Second Circuit created another type of Equity Extraterritoriality situation: adjudicating the claims of the parties outside of its jurisdiction by asserting jurisdiction over a third party intermediary and the property under the intermediary's (constructive) control.

It is not an exaggeration to say that if the holding in Winter Storm had been pushed to the fullest extent allowed by the current Equity Extraterritoriality doctrine, banking in New York as we know it would have ceased to exist. Just a small taste of the coming doom was enough for the Second Circuit to completely reverse its course just seven years later, in

248. See discussion supra Section IV.B.3.

249. See discussion supra Section IV.A.2.

250. Winter Storm Shipping v. TPI, 310 F.3d 263, 268 (2d Cir. 2002) 
Shipping Corp. of India v. Jaldhi Overseas PTE Ltd. ${ }^{251}$ The Second Circuit's opinion in Jaldhi, explicitly overturning Winter Storm, is a rare display of judicial self-flagellation. The court noted that, thanks to Winter Storm, onethird of all lawsuits filed with the Southern District of New York were Rule B maritime attachment applications. ${ }^{252}$ Every day, major banks were served with 800 to 900 restraining notices from creditors who issued multiple restraining notices throughout the day in hopes to stop the EFT in the few hours that the intermediary banks took to process the transfer. ${ }^{253}$ The sheer volume of the restraining notices caused so many false identifications of the transfer to be restrained that it disrupted the entire process of electronic fund transfer. ${ }^{254}$ The court noted that this uncertainty threatened New York's standing as a center of international banking, and even the status of the U.S. dollar as the world's primary reserve currency, as foreign corporations avoided wiring money through New York in dollar-denominated EFTs. ${ }^{255}$

But the self-flagellation in Jaldhi is not the only remarkable aspect of the opinion. Jaldhi is also remarkable in that it had very little legal analysis for an opinion that so completely disavows the governing precedent decided only years earlier. The court in Jaldhi found that Winter Storm should not have relied on United States v. Daccarett, ${ }^{256}$ a Second Circuit precedent on criminal forfeiture. But the opinion in Jaldhi provides no legal explanation as to why Winter Storm was wrong to rely on Daccarett, a valid Second Circuit precedent; the opinion only points to the long recitation of Winter Storm's "unforeseen consequences." ${ }^{257}$ A more robust doctrine of Equity Extraterritoriality could have provided the missing explanation. If the court had recognized its exercise of Equity Extraterritoriality was in fact an extraterritorial application of the U.S. law, it would have been more cautious in issuing an opinion like Winter Storm that, in all practicality, adjudicated the obligations between two foreign parties. If territoriality principles applied to Equity Extraterritoriality, the court in Winter Storm would have treaded cautiously, giving due deference to the foreign interests involved. But that is not the state of the Equity Extraterritoriality doctrine today; the Second Circuit could not offer any legal reasoning in Jaldhi because Equity

251. Shipping Corp. of India v. Jaldhi Overseas PTE Ltd., 585 F.3d 58, 62 (2d Cir. 2009).

252. See id.

253. See id. (quoting Cala Rosa Marine Co. Ltd. v. Sucres et Deneres Group, 613 F. Supp. 2d 426, 431-32 n. 7 (S.D.N.Y. 2009)).

254. See id.

255. See id. at 61-62.

256. 6 F.3d 37, 59 (1993).

257. See Jaldhi, 585 F.3d 58 at 62; see also id. at 68 ("Upon further consideration, we find Winter Storm's reasons unpersuasive and its consequences untenable."). 
Extraterritoriality has no limiting principle other than the court's own sense of discretion. Thus, when its sense of discretion malfunctioned, the court could only point to the disastrous consequences that came as a result of its decision, rather than a principled, legal reason why its decision was wrong.

\section{Inconsistent Application of Territoriality}

It is worth repeating that U.S. law's concern with territoriality is almost entirely focused on the area of judicial and legislative jurisdiction. U.S. legal doctrine on jurisdiction operates under the presumption against extraterritoriality, and treads gingerly when the U.S. law does assert jurisdiction beyond the U.S. borders, lest it should infringe upon the province of a foreign sovereign. Equity Extraterritoriality, in contrast, has no such concern-which means Equity Extraterritoriality allows a party to achieve what it could not under the ordinary application of territoriality principles. This has been true of Equity Extraterritoriality since the early days of the United States: a court may order a debtor to deliver a property located beyond the court's territorial border to satisfy a debt, although the court could not change the title of the extraterritorial property. ${ }^{258}$ This is a facile distinction that many commentators have criticized for more than a hundred years. ${ }^{259}$ As Professor Linda Silberman aptly put it, the distinction makes the absurd claim that "an accused is more concerned with where he will be hanged than whether." 260 Yet the Supreme Court continues to maintain this distinction, explicitly stating in Baker that "a sister State's decree concerning land ownership in another State has been held ineffective to transfer title, although such a decree may indeed preclusively adjudicate the rights and obligations running between the parties to the foreign litigation." $" 261$

Sophisticated parties and their attorneys are exploiting this gap between the two doctrines. The Argentina bond case is the most sensational example. Under the FSIA, which is an expression of the principle of sovereign immunity that underlies territoriality principles, a foreign sovereign enjoys immunity from execution against its property located outside the United States. ${ }^{262}$ The court bypassed this immunity by issuing an injunction against the Republic of Argentina, effectively compelling Argentina to bring its extraterritorial, and immune, assets into the United States to pay its

258. See discussion supra Section III.A.

259. See discussion supra Section III.B.1.

260. Linda J. Silberman, Shaffer v. Heitner: The End of an Era, 53 N.Y.U. L. REV. 33, 88 (1978).

261. Baker by Thomas v. General Motors Corp., 522 U.S. 222, 235 (1998) (internal citations omitted; emphasis in original).

262. 28 U.S.C. $\S \S 1609-10$. 
creditors. $^{263}$ In the end, this is exactly what Argentina did by settling with its creditors. ${ }^{264}$ Another example is the popularity of "judgment arbitrage," in which multinational creditors bring a foreign judgment to be domesticated in the U.S., to rely on the broad reach of Equity Extraterritoriality in the postjudgment context. ${ }^{265}$ At least two New York courts have held that there is no jurisdictional requirement for an action to obtain recognition of a foreign judgment. ${ }^{266}$ This means that a judgment creditor may bring a money judgment from any foreign court and convert it into a New York judgment. With the newly minted New York judgment, the creditor may engage in the far-reaching extraterritorial asset discovery and obtain asset turnover orders against anyone over whom the New York court is willing to assert personal jurisdiction (most likely a third party intermediary, like a bank in New York). ${ }^{267}$ One may address this issue by introducing jurisdictional or other requirements for giving recognition to foreign judgments. ${ }^{268}$ But the more fundamental cause of this issue is the reason why foreign creditors come to New York courts in the first place - the ability to reach any part of the world through the Equity Extraterritoriality orders that New York courts may make in the course of judgment enforcement. ${ }^{269}$

These inconsistencies in the application of territoriality undermine the confidence in the rule of law. Many commentators who observed the inconsistent application of territoriality offer a cynical explanation. Professor Jonathan Turley, for example, argued that the U.S. territoriality doctrine has been applied selectively, allowing "market" cases like ones

263. See Cross, supra note 124, at 137-38.

264. See Vinod Sreeharsha, Argentina's Senate Votes to Allow Payment to U.S. Bondholders, N.Y. TIMES, Mar. 31, 2016 at B2.

265. See Gregory H. Shill, Ending Judgment Arbitrage: Jurisdictional Competition and the Enforcement of Foreign Money Judgments in the United States, 54 HARV. INT'L L.J. 459, 460 (2013). See also Marcus S. Quintanilla and Christopher A. Whytock, New Multipolarity in Transnational Litigation: Foreign Courts, Foreign Judgments, and Foreign Law, 18 SW. J. INT'L L. 31, 35-37 (2011) (projecting a significant increase in foreign judgment creditors attempting to obtain recognition of judgment from U.S. courts).

266. See Abu Dhabi Comm. Bank PJSC v. Saad Trading, Contracting and Fin. Svcs. Co., 986 N.Y.S. 2d 454, 613 (N.Y. App. Div. 1st Dep’t 2014); Lenchyshyn v. Pelko Elec. Inc., 723 N.Y.S. 2d 285, 292 (N.Y. App. Div. 4th Dep't 2001).

267. See N.Y. C.P.L.R. § 5201 (2015) (providing for third party garnishment); id. $\$ 5223$ (providing for post-judgment asset discovery); $i d . \S 5225$ (providing for delivery of debtor property).

268. For discussion on adding requirements for foreign judgment recognition to prevent abuse, see Linda J. Silberman and Aaron D. Simowitz, Recognition and Enforcement of Foreign Judgments and Awards: What Hath Daimler Wrought?, 91 N.Y.U. L. REV. 344, 359 (2016).

269. See id. at 385 ("creditors enforcing judgments or awards in the United States typically seek two particular remedies - discovery of the debtor's assets within and without the state and turnover of the debtor's assets held by third parties. These remedies are powerful tools and class in personam remedies that may extend beyond the territorial borders of the United States."). 
involving the Sherman Act to apply extraterritorially while "nonmarket" cases faced the presumption against extraterritoriality. ${ }^{270}$ Similarly, Professor Mark Gibney argued that "U.S. law has been applied extraterritorially when that has served the national interest of the United States or its corporate actors, and it has been given a territorial application when a restrictive interpretation would serve those same ends."271 This perception of situational application of the law will continue until territoriality principles apply to the operation of Equity Extraterritoriality in a meaningful way.

3. Fostering Inconsistency Within Jurisdictional Territoriality

The problem of inconsistency caused by Equity Extraterritoriality does not merely plague the application of the territoriality doctrine as a whole. The very availability of Equity Extraterritoriality fosters inconsistency within jurisdictional territoriality, or on how territoriality principles apply to personal jurisdiction.

As noted earlier, U.S. courts often raise the threat of force against extraterritorial persons or property by using extraterritorial jurisdiction and Equity Extraterritoriality together. Earlier, we used the example of extraterritorial document discovery to see Equity Extraterritoriality induces compliance with the U.S. laws from persons located outside of the territorial boundaries of the United States long before the court establishes jurisdiction over them. ${ }^{272}$ The threat of force, in that instance, is the threat of U.S. court finding jurisdiction over a person located beyond its territorial jurisdiction, and issuing extraterritorial orders pertaining to properties (i.e. documents) located beyond its territorial jurisdiction.

The unpredictability of jurisdictional extraterritoriality does much to fuel the strength of Equity Extraterritoriality. While it is true that the Supreme Court in recent years greatly strengthened the territorial limitations on jurisdiction, a number of legal theories are still available for a U.S. court that wishes to exercise extraterritorial jurisdiction. The Supreme Court's endorsement of "tag" jurisdiction in Burnham — denounced as "closer . . . to robbery than justice" ${ }^{273}$ _ remains good law. ${ }^{274}$ The same is true for general

270. See Jonathan Turley, "When in Rome": Multinational Misconduct and the Presumption Against Extraterritoriality, 84 Nw. U. L. REV. 598, 608 (1990).

271. Mark P. Gibney, The Extraterritorial Application of U.S. Law: The Perversion of Democratic Governance, the Reversal of Institutional Roles, and the Imperative of Establishing Normative Principles, 19 B.C. INT'L \& COMP. L. REV. 297, 304-05 (1996).

272. See discussion supra Section II.A.

273. Albert A. Ehrenzweig, The Transient Rule of Personal Jurisdiction: the "Power" Myth and Forum Conveniens, 65 YALE L.J. 289, 290 (1956).

274. See, e.g., Kadic v. Karadzic, 70 F.3d 232, 251 (2d Cir. 1995) (asserting personal jurisdiction 
jurisdiction over foreign corporations "doing business" in the United States through affiliates, although Daimler did significantly reduce its application. ${ }^{275}$ The interaction between Equity Extraterritoriality and the "effects" test deserves emphasis. Numerous commentators have criticized the "effects" test, the "Great Grimpen Mire"276 of a legal doctrine that the courts have applied "[w]ith almost haphazard nonchalance." reaching "effects" test, a holdover doctrine from the mid-20th century personal jurisdiction revolution, remains a favorite among courts that seek to extend their jurisdiction beyond their territorial boundaries. ${ }^{278}$ This, in turn, extends the reach of Equity Extraterritoriality.

However, it is important to note that the reverse is also true. It is not merely that jurisdictional extraterritoriality strengthens Equity Extraterritoriality; the availability of unchecked Equity Extraterritoriality causes further extension of jurisdictional extraterritoriality. Because there is no territorial restriction on the reach of Equity Extraterritoriality after the court obtains personal jurisdiction, the parties are incentivized to push the court to assert extraterritorial jurisdiction as much as possible, in order to access the extraterritorial orders that become available once jurisdiction is established. The parties, then, naturally focus on the weakness within the territoriality principles in the personal jurisdiction doctrine, namely the inconsistency between the presumption against extraterritoriality and the various theories of extraterritorial jurisdiction, including the "minimum contacts"/"effects" test. Often, this endeavor results in a situation where the tail wags the dog: because Equity Extraterritoriality seems necessary, the court summons the "effects" test as a post hoc justification for its power. This is evident in In re Rimsat, Ltd., in which Judge Posner found that the automatic stay provision in the Bankruptcy Code applied to extraterritorial

over individual who was served within the forum); Doe I v. Liu Qi, 349 F. Supp. 2d 1258, 1275 (N.D Cal. 2004) (same).

275. See post-Daimler cases such as: Hume v. Farr's Coach Lines, Ltd., 2015 U.S. Dist. LEXIS 133000 (W.D.N.Y. Sept. 30, 2015) (ordering further jurisdictional discovery over a Canadian corporation to assess the potential basis of "doing business" general jurisdiction); Helsinn Healthcare S.A. v. Hospira, Inc., 2016 U.S. Dist. LEXIS 45826 (D.N.J. Apr. 5, 2016) (finding continued validity of "doing business" general jurisdiction over an out-of-state corporation that appointed an agent for service of process in the forum state).

276. Joseph E. Fortenberry, Jurisdiction Over Extraterritorial Antitrust Violations-Paths Through the Great Grimpen Mire, 32 OHIO ST. L.J. 519, 519 (1971).

277. Gary B. Born \& Peter B. Rutledge, International Civil Litigation in the United StATES 658-59 (4th ed. 2007). See also Larry Kramer, Vestiges of Beale: Extraterritorial Application of American Law, 1991 SUP. CT. REV. 179, 179-80 (1991); Gibney, supra note 271, at 302; Parrish, supra note 123 , at 1480 .

278. See Parrish, supra note 123, at 1457 ("At the heart of most extraterritoriality cases lies the effects test."). 
assets because "[t]he efficacy of the bankruptcy proceeding depends on the court's ability to control and marshal the assets of the debtor wherever located," 279 without making any further attempt to square the need of the bankruptcy court with the presumption against extraterritorial interpretation of the Bankruptcy Code.

This problem is particularly visible when the court compounds Equity Extraterritoriality by issuing an order against an extraterritorial third party who violated the court's (separate) extraterritorial order. In Waffenschmidt v. Mackay, the Fifth Circuit Court of Appeals held that nonparties residing outside the territorial jurisdiction of a district court were subject to that court's contempt jurisdiction if they knowingly aided and abetted a party violating the court's order, even if such nonparties had no other contact with the forum. ${ }^{280}$ The court found that the nonparty's interference with the court's order alone constituted sufficient minimum contact, because such interference caused a substantial effect in the forum. ${ }^{281}$ The Seventh Circuit reached a similar conclusion in S.E.C. v. Homa, also based on the "effects" test. ${ }^{282}$ In no other context would the court leverage such a tenuous connection to the forum to assert extraterritorial personal jurisdiction. Under ordinary circumstances, it is a settled rule that the court cannot assert specific jurisdiction over an out-of-state defendant whose only contact with the forum is through the plaintiff. ${ }^{283}$ But in Waffenschmidt and Homa, two Circuit Courts have declared that they have personal jurisdiction over an extraterritorial third party whose only contact with the forum is through the court's extraterritorial order, based on the "effects" test. Under this formulation, there is simply no corner in the world that the court cannot reach: the court may first establish extraterritorial jurisdiction by way of any one of the long-arm jurisdiction theories, then issue extraterritorial orders pursuant to Equity Extraterritoriality, and then assert jurisdiction over any extraterritorial third party that may interfere with the enforcement of that

279. 98 F.3d 956, 961 (7th Cir. 1996).

280. 763 F.2d 711, 721 (5th Cir. 1985).

281. See id. at $722-23$.

282. 514 F.3d 661, 673-75 (7th Cir. 2008); see also ClearOne Commc'ns, Inc. v. Bowers, 651 F.3d 1200, 1215-16 (10th Cir. 2011) (affirming that a "district court may properly exercise personal jurisdiction over a nonparty for purposes of entering contempt orders, when the nonparty, with actual notice of an injunctive order issued by the district court, and in active concert or participation with a party, violates that order"); but see Gucci Am., Inc. v. Bank of China, 768 F.3d 122, 137 (2d Cir. 2014) (noting that in Waffenschmidt, the nonparties at issue were out of the court's territorial jurisdiction but still within the United States, and that in Нoma, although the nonparties were outside of the United States, they were U.S. citizens).

283. See World-Wide Volkswagen Corp. v. Woodson, 444 U.S. 286, $298-99$ (1980); McIntyre Mach. v. Nicastro, 564 U.S. 873, 886-87 (2011). 
extraterritorial order. Indeed, this is essentially what happened to the third party European banks in the Argentina bond litigation. ${ }^{284}$

The existence of Equity Extraterritoriality itself appears to motivate this jaw-dropping declaration that there is no corner of the world that the court cannot reach. The court must be able to enforce its own order; if the order happens to be extraterritorial, how else is the court supposed to enforce its order other than by exercising extraterritorial jurisdiction over the person outside of the court's territorial jurisdiction? Yet such an exercise of jurisdiction is plainly inconsistent with other territorial limitations upon personal jurisdiction, such as presumption against extraterritoriality. The availability of Equity Extraterritoriality motivates the courts to perpetuate such inconsistency, rather than to streamline the personal jurisdiction doctrine along the lines of territoriality principles.

4. Transnationality Blindness

Yet another critical area of underdevelopment in Equity Extraterritoriality is what may be termed "transnationality blindness" - the lack of distinction between domestic and international litigation. This, in fact, is a cognitive challenge from which the entire U.S. transnational litigation jurisprudence suffers. Facing transnational litigation, U.S. courts generally equate foreign nations with one of the U.S. states, with little to no separate consideration for foreign policy implications that may arise with the foreign nations. ${ }^{285}$ Although eminent commentators have long criticized this peculiar tendency, ${ }^{286}$ transnationality blindness continues to affect all stages of litigation in the United States, including jurisdiction, ${ }^{287}$ provisional

284. See discussion supra Section IV.A.2.

285. See, e.g., Stephen B. Burbank, Practice and Procedure: the World in Our Courts, 89 MICH. L. REV. 1456, 1458-59 (1991) (raising doubt as to whether transnational litigation may be considered a separate field within the U.S. law); Graeme B. Dinwoodie, International Intellectual Property Litigation: A Vehicle for Resurgent Comparativist Thought?, 49 AM. J. CoMP. L. 429, 431-433 (2001) (noting that transnational intellectual property disputes are treated in the same manner as domestic disputes).

286. See, e.g., Barcelona Traction, Light \& Power Co. (Belg. v. Spain), Judgment, 1970 I.C.J. 3, 167 (Feb. 5) (Jessup, J.) (stating that jurisdictional rules which are "valid enough for inter-state conflicts within the constitutional system of the United States, may be improper when placing a burden on international commerce").

287. See Donald E. Childress III, Rethinking Globalization: the Case of Transnational Personal Jurisdiction, 54 WM. \& MARY L. REV. 1489, 1548 (2013) (proposing a new rule on personal jurisdiction specifically for nonresident alien defendants). 
orders, ${ }^{288}$ and judgment recognition. ${ }^{289}$ This lacuna is evident from the history of Equity Extraterritoriality as well, as courts weighing in on Equity Extraterritoriality cases have rarely paused to give an extra layer of consideration for international cases. ${ }^{290}$

Equity Extraterritoriality may arise in two ways, domestic and international: a court of one state may issue an extraterritorial order binding persons and conducts in another state, or; a U.S. court may issue an extraterritorial order binding persons and conducts in another country. ${ }^{291}$ U.S. jurisprudence views both instances as qualitatively the same. While such a view may be defensible in theory, as a practical matter, an intrafederation dispute and an inter-national dispute plainly have very different implications. Ignoring such implications "elevates domestic interests over international considerations." 292 That is to say: transnationality blindness results in an anomalous situation in which a domestic party receives more procedural safeguards than a foreign party, although the latter would have the greater need for those safeguards.

Domestic Equity Extraterritoriality has a number of legal and practical safeguards to prevent the most outrageous forms of the court's extraterritorial excursions. Chief among the safeguards is the Constitution of the United States, which serves as a device for harmonizing multiple claims of sovereignty made by the various states. ${ }^{293}$ The states send their representatives to the federal legislature, which passes statutes of general

288. See George A. Bermann, Provisional Relief in Transnational Litigation, 35 ColuM. J. TRANSNAT'L L. 553, 560 (1997) (noting U.S. courts' indifference toward parties' nationalities in granting provisional relief); S. Nathan Park, Recognition of Enforcement of Foreign Provisional Orders in the United States: Toward a Practical Solution, 38 U. PA. J. INT'L L. 999, 1034 (2017) (noting the discrepancy posed by U.S. courts' indifference toward parties' nationalities in granting provisional relief).

289. See Peter D. Trooboff, Ten (and Probably More) Difficulties in Negotiating a Worldwide Convention on International Jurisdiction and Enforcement of Judgments: Some Initial Lessons, in A GLOBAL LAW OF JURISDICTION AND JUDGMENTS: LESSONS FROM THE HAGUE 263, 264 (John J. Barcelo III \& Kevin M. Clermont eds., 2002) ("In general, American courts have not subjected judgments of the courts of other nations to a separate test to determine whether they are entitled to recognition and enforcement.").

290. See, e.g., Burbank, supra note 159, at 1334 (criticizing Grupo Mexicano for failing to "take account of special needs and concerns when foreign parties are involved"); see also RESTATEMENT (SECOND) OF CONFLICT OF LAWS $§ 102 \mathrm{cmt}$. g. (AM. LAW. INST. 1971) (calling for recognition of foreign injunctive orders because "American courts ... have usually given the same measure of respect to judgments rendered in foreign nations ... that they give to judgments rendered in sister States").

291. See discussion supra Section II.B.

292. Hannah L. Buxbaum, Territory, Territoriality, and the Resolution of Jurisdictional Conflict, 57 AM. J. CoMP. L. 631, 649 (2009).

293. See, e.g., Welkowitz, supra note 23, at 80 (noting that the Commerce Clause, Full Faith and Credit Clause, and the Tenth Amendment of the U.S. Constitution necessarily limits a state court's extraterritorial reach). 
applicability. ${ }^{294}$ When there is a dispute as to the applicability of the federal statutes, the states and their residents ultimately submit to the jurisdiction of the U.S. Supreme Court, ${ }^{295}$ the highest court of the land that conclusively resolves the dispute by referring to an established and shared legal tradition. The various states of the United States have centuries of common history, language and culture, such that the real-life impact of an extraterritorial court order is minimized as a practical matter. Taken together, this means that more often than not, domestic Equity Extraterritoriality disputes are essentially disputes concerning the determination of the proper venue rather than a true clash of sovereign authorities.

Same cannot be said for Equity Extraterritoriality in the context of transnational litigation. There is no superstructure that governs the many nations of the world in a manner similar as the federal government governs the states within the United States. For example, the U.S. Congress attempted to address the Equity Extraterritoriality issue in 1927 by proposing a bill that would have required state and federal courts to accord full faith and credit to all injunctive and other equitable decrees. ${ }^{296}$ The failure of the bill - the first and only attempt to resolve the problem of Equity Extraterritoriality by federal legislation-serves as a sad testament for the severe underdevelopment of the doctrine, even in the domestic context. ${ }^{297}$ But in the international context that lacks the overarching legislature that is analogous to the Congress of the United States, this type of legislative harmonization is completely unavailable, leading to the free-for-all battles that international Equity Extraterritoriality often generates. The states within the United States, for instance, generally would not pass blocking statutes to protest another state's exercise of sovereignty beyond its territorial borders, unlike the numerous national governments that passed blocking statutes in order to protest the application of U.S. laws. In the domestic context, the federal government generally would have headed off the dispute before it reached the stage at which sister states each passed a law to block the laws

294. See U.S. CONST. ART. I.

295. See U.S. CONST. ART. III; see also Messner, supra note 77, at 526 (noting that the Constitution's Full Faith and Credit clause would govern Equity Extraterritoriality, requiring sister state courts to recognize the force of other state courts' extraterritorial injunctions).

296. See Report of the Standing Committee on Jurisprudence and Law Reform, 50 ANNU. REP. ABA. 292, 319 (1927).

297. See also Price, supra note 24, at 760 ("Only a few courts have held unequivocally that full faith and credit must be accorded permanent injunctions of sister states. Even in these instances, however, it is unclear whether the underlying theory is more akin to recognition of the res judicata effect of the prior proceeding, or that the injunction is directly enforceable in the second state."). 
of other states. ${ }^{298}$ This lack of superstructure in the international arena brings about an upside-down world in transnational litigation: although a foreign party requires greater procedural safeguards to prevent being haled into an unfamiliar court and become subject to an extraterritorial order that may create conflicting legal obligations, Equity Extraterritoriality doctrine gives less protection to the foreign party compared to the domestic party in the same situation.

\section{SOLVING THE PROBLEM OF EQUITY EXTRATERRITORIALITY}

The problem of Equity Extraterritoriality is a problem of extraterritoriality and underdevelopment, which is bound to become worse as the needs of modern commerce place increasingly greater pressure on the underdeveloped doctrine. What can be done to address this problem? The nature of Equity Extraterritoriality would require a two-track approach: one for interstate/domestic instances of Equity Extraterritoriality, and another for international. Domestic Equity Extraterritoriality is the easier to fix, as there are constitutional principles that may be utilized to harmonize the territorial sovereignty of various states. Reining in the excess of international Equity Extraterritoriality, on the other hand, would require a new framework. In this section, I propose a sovereignty-allocating legal test that harkens back to the origin of the territoriality principles, by forging a practical application of the principle of international comity. My proposed solution injects the comity concern into the framework of conflict of laws, resulting in a more muscular test that demands the court to give due consideration for the interests of the foreign sovereign.

\section{A. Devising a Solution for Equity Extraterritoriality}

The mechanism of Equity Extraterritoriality relies on two links of control: a court relies on the unpredictable personal jurisdiction doctrine to control the person with extraterritorial capacity (such as a multinational corporation) and then orders the person to take actions beyond the court's territorial jurisdiction. The solution, then, must be twofold as well: on the front end of litigation, install a more consistent standard for establishing extraterritorial jurisdiction to guard against the erratic exercise of long-arm jurisdiction and, on the back end of litigation, place additional safeguards against extraterritorial orders based on territoriality principles.

298. Cf. Defense of Marriage Act, Pub. L. No. 104-199 (1996) (federal statute allowing each state to refuse to give recognition to same-sex marriage consummated in a sister state). 
It is beyond the scope of this paper to address in depth the first part of the solution, involving personal jurisdiction. Much ink has been spilled about creating a more definite and consistent limit on the court's assertion of extraterritorial jurisdiction. ${ }^{299}$ To that end, the U.S. courts' recent trend of avoiding transnational litigation is encouraging. ${ }^{300}$ In addition to the recent Supreme Court cases discussed earlier ${ }^{301}$ the court's opinion in Sinochem International Co. v. Malaysia International Shipping Corp. does much to assist the lower courts navigating the personal jurisdiction issue in transnational cases. ${ }^{302}$ In Sinochem, the court found that forum non conveniens dismissal was available at any stage of the litigation, even before the court establishes personal and subject matter jurisdiction. ${ }^{303}$ Although this trend of "litigation isolationism" is not without its problems, ${ }^{304}$ such retrenchment would at least partially address the problems of Equity Extraterritoriality by cutting back on the U.S. judiciary's interaction with the international arena, which would then reduce the necessity for the U.S. courts to issue extraterritorial orders.

But streamlining the personal jurisdiction doctrine alone is insufficient to address the full extent of the problems posed by Equity Extraterritoriality. There are plenty of situations in which the court's claim of personal jurisdiction is unassailable, but the court's extraterritorial order causes a problem regardless. In the Argentina bond case, for example, the Republic of Argentina partially waived its sovereign immunity by voluntarily submitting itself to the U.S. court's jurisdiction in relation to its bonds. ${ }^{305}$ Thus, the New York federal court's jurisdiction over Argentina was never in question. But Argentina retained other types of sovereign immunity, including immunity against execution of the assets that it owned. ${ }^{306}$ It is this execution immunity of Argentina-which Argentina never relinquishedthat the New York federal court overrode by resorting to Equity Extraterritoriality, i.e. by prohibiting Argentina from paying the creditors

299. For a well-considered discussion on finding consistency in the doctrine of personal jurisdiction, see, e.g., Silberman \& Simowitz, supra note 268, at 393-95; Stephen E. Sachs, Pennoyer was Right: Jurisdiction and General Law, 95 TEX. L. REV. 1249, 1315-16 (2017).

300. See Bookman, supra note 127 , at 1119.

301. See discussion supra Section III.C.1.

302. See 549 U.S. 422, 432-35 (2007).

303. See id. at 432 ("A district court therefore may dispose of an action by a forum non conveniens dismissal, bypassing questions of subject-matter and personal jurisdiction, when considerations of convenience, fairness, and judicial economy so warrant.").

304. See Bookman, supra note 127, at 1136 (noting the possibility that "litigation isolationism" may lead to a compromise in U.S. sovereign interest of hearing Americans' disputes in American courts).

305. See NML Capital v. Arg., 699 F.3d 246, 263 (2d Cir. 2013).

306. See 28 U.S.C. $§ 1609$ (2012). 
that held new exchanged bonds, regardless of where the payment might occur, unless it also paid the holders of the old non-exchanged bonds that Argentina tried to restructure. ${ }^{307}$ In this instance, the problem of Equity Extraterritoriality arises independently from the problem of extraterritorial jurisdiction. For an alternative example, recall the augmented-reality smartphone game developed by a U.S. videogame company that records physical movements of an Australian gamer. ${ }^{308}$ A court of the United States would have a perfectly valid claim of jurisdiction over the U.S. videogame company. Yet the court may order the U.S. company to produce the location data of an Australian citizen and resident - at which point the Australian sovereign may have a legitimate interest in protecting the privacy of its subjects. Here again, the problem of extraterritorial jurisdiction and the problem of Equity Extraterritoriality are not coterminous. Further, as discussed above, the very availability of Equity Extraterritoriality hinders the streamlining of personal jurisdiction doctrine, as parties are incentivized to push the court to exercise expansive jurisdiction so that they may obtain an extraterritorial Equity order. ${ }^{309}$

Equity Extraterritoriality, therefore, must be addressed on its own terms, rather than as a side effect of jurisdictional extraterritoriality. The problem of extraterritoriality may arise on the front end of the litigation, as well as on the back end. Finding the legal principles that may serve as safeguards against the abuse of extraterritoriality on the back end of the litigation - the portion governed by Equity Extraterritoriality-is the more urgent part of the problem, precisely because so little attention is paid to it.

As noted earlier, the problem of Equity Extraterritoriality may arise in two contexts: interstate/domestic and international. The instances of domestic and international Equity Extraterritoriality require two different responses, because the environments in which these two arise are markedly different.

\section{Domestic Equity Extraterritoriality}

"Domestic" Equity Extraterritoriality, i.e. extraterritorial court orders whose ordered activities occur within the United States, is the easier problem to address. The stakes are lower for the problem of domestic Equity Extraterritoriality, as it is nearly interchangeable with the question of proper venue within the United States to issue the court order. Further, the legal

307. See NML Capital, 699 F.3d at 254-55; see also Cross, supra note 124, at 111; Pomager, supra note 124 , at $349-50$.

308. See discussion supra Section IV.A.2.

309. See discussion supra Section IV.C.3. 
principles that may serve as limiting principles already exist. The problem is not so much a lack of structure but a lack of development. The foundational principles to harmonize the various states' territorial sovereignty are already in place in the form of the U.S. Constitution, and the institutional infrastructure to implement the principles are also in place in the form of the U.S. Supreme Court. Stated differently, the problem of domestic Equity Extraterritoriality is a problem of neglect, of the kind that the Supreme Court would be able to address with a few opinions. ${ }^{310}$ Accordingly, I present here only a brief overview of the proposed solution.

At least five constitutional principles are available to limit the reach of state courts (which include federal courts applying state law) beyond the state boundary lines: separation of powers, federalism, Commerce Clause, Full Faith and Credit Clause, and the Tenth Amendment. Evaluating Equity Extraterritoriality in light of these five constitutional principles makes visible the limits of extraterritorial power that a state court sitting in equity may wield. That is to say, the necessary consequence of these principles is that there is a constitutional limit as to a state court's exercise of extraterritorial powers.

Separation of powers and federalism set the outer edges of domestic Equity Extraterritoriality by limiting a state court's extraterritorial authority to the territorial boundaries of the United States, because the state court's Equity Extraterritoriality beyond the U.S. borders impermissibly infringes upon the power to conduct foreign policy given exclusively to the political branches of the federal government. ${ }^{311}$ The Commerce Clause, Full Faith and Credit Clause and Tenth Amendment define the extent to which a state court may reach beyond its territorial jurisdiction within the United States. ${ }^{312}$ The Tenth Amendment, on its face, guarantees the sovereignty of the various states. ${ }^{313}$ Such sovereignty is to be harmonized through the workings of the federal government, including the U.S. Supreme Court. ${ }^{314}$ Commerce Clause protects the federation from internally inconsistent economic regulations that may be caused by each state's extraterritorial overreach. ${ }^{315}$

310. Legislative intervention, of course, is also an option. In the context of intellectual property, for example, the relevant statutes provide for nationwide injunctive power from a federal district court. See, e.g., Trademark Act $\S 35,15$ U.S.C. $\$ 1116$ (2012).

311. See U.S. Const. art. I, $\S \S 8,10 ; i d$. art. II, $\S 2$.

312. See Welkowitz, supra note 23, at 80.

313. See U.S. CONST. amend. X.

314. See Garcia v. San Antonio Metropo. Transit Auth., 469 U.S. 528, 552 (1985) (rejecting the claim based on the Tenth Amendment that a state agency is immune from federal law).

315. See Healy v. Beer Inst., Inc., 491 U.S. 324, 332 (1989) ("our established view [is] that a state law that has the 'practical effect' of regulating commerce occurring wholly outside of the State's borders 
The Full Faith and Credit Clause requires the states to "respect the legitimate interest of other States and avoid infringement upon their sovereignty"316 by setting the standard as to which state court orders deserve recognition and which do not.

Of course, these five principles do not give the precise line of limitation upon a state court's claim of Equity Extraterritoriality. But collectively, these constitutional doctrines give the general contours of the principles that may serve to limit the excess of domestic Equity Extraterritoriality. Further, the Supreme Court has implied in several opinions that no single constitutional provision contains the territoriality principle for the states. ${ }^{317}$ Given the foregoing, it is a relatively easy task for the Supreme Court to locate some type of constitutional limitation on domestic Equity Extraterritoriality.

2. International Equity Extraterritoriality

International Equity Extraterritoriality is a different matter. None of the superstructures imposed on top of the various states within the United States exist above the various nations of the world. Also, the stakes are higher. As a practical matter, domestic Equity Extraterritoriality does not amount to much more than a battle to determine a proper venue that may issue the court order. If domestic Equity Extraterritoriality heats up beyond the venue fight, one can expect that national legislation would be introduced to address the issue. ${ }^{318}$ That is not so in the case of international Equity Extraterritoriality: when courts of two national sovereigns collide, the result is almost always a free-for-all in which one national court pressures the other to capitulate. ${ }^{319}$ This is the result to be avoided. One obvious step to take is to drop the transnationality blindness and insist that U.S. courts apply a different rule when a case involves a foreign element. This much is possible by applying

is invalid under the Commerce Clause.”); Edgar v. MITE Corp., 457 U.S. 624 (1982) (striking down Illinois state law that regulates transactions that take place across state lines); Japan Line Ltd. v. County of Los Angeles, 441 U.S. 434, 448 (1979) (striking down local taxes on shipping containers because foreign commerce is "preeminently a matter of national concern.").

316. Allstate Ins. Co. v. Hague, 449 U.S. 302, 322 (1981) (Stevens, J. concurring).

317. See Welkowitz, supra note 23, at 80-81 (noting that several Supreme Court opinions, such as Goldstein v. California, 412 U.S. 546, 546 (1973) and Edgar, 457 U.S. at 624, did not cite the Constitution to apply territorial limitations upon state intellectual property regulations).

318. See Welkowitz, supra note 23, at 58 ("Just as the sovereign interest of the states vis-à-vis the federal government may be protected by their representation in the federal government, the sovereign interests of states vis-à-vis each other may be protected by their ability to protect those interests through national legislation.”).

319. See, e.g., Laker Airways Ltd. v. Sabena, Belgian World Airlines, 731 F.2d 909, 932-36 (D.C. Cir. 1984). 
the existing constitutional doctrine on federalism and separation of powers. ${ }^{320}$ Beyond that, however, there is no off-the-shelf legal principle with which to limit the reach of international Equity Extraterritoriality.

The history of Equity Extraterritoriality may offer some guidance in identifying a limiting principle that may be of service, because Equity Extraterritoriality has not always been as unbridled as it is today. Looking back on Equity Extraterritoriality's history, three moments that restricted the reach of Equity Extraterritoriality stand out. In Amey, Judge Hand limited the application of Equity Extraterritoriality to enforcement of concrete and previously existing personal obligation. ${ }^{321}$ In Pennoyer, the Supreme Court limited the application of Equity Extraterritoriality to those persons found and served within the court's territorial jurisdiction. ${ }^{322}$ And in 17th century England, the equity court dispensed Equity Extraterritoriality selectively as exceptions to the general rule of territoriality to which the common law courts adhered. ${ }^{323}$ All three moments offer examples of the limits that may be placed on Equity Extraterritoriality. But it is far too late in the day to actually implement any one of these three types of limitations. The Amey limitation would mean turning back the clock on the modern regulatory state, as it excludes Equity Extraterritoriality from being applied to enforce a general, statutory obligation instead of a previously existing personal obligation. Enforcing the Pennoyer-style strict territoriality in jurisdiction is not feasible in a world in which many nations are moving toward effectsbased jurisdiction, ${ }^{324}$ and at any rate, it ultimately commits the same error that today's Equity Extraterritoriality doctrine does-namely, depending entirely on the front end of the litigation to regulate the extraterritorial excursions occurring at the back end of the litigation. Finally, reverting U.S. law to the times prior to the merger of law and equity simply to address the extraterritoriality problem is out of the question, despite the inchoate efforts by Justice Scalia in Grupo Mexicano v. All. Bond Fund, Inc. ${ }^{325}$

If we cannot turn back time, what remains to be learned from history? Although history may not offer an off-the-shelf solution, we may yet find in history the principle needed to build an appropriate new legal test. The

320. See discussion supra Section IV.C.4.

321. See discussion supra Section III.B.1.

322. See discussion supra Section III.A.

323. See discussion supra Sections III.A. and III.B.2.a.

324. See S.S. Lotus (Fr. v. Turk.), 1927 P.C.I.J. (ser. A) No. 10, at 16 (Judgment of Sept. 7); Raustiala, supra note 2, at 125.

325. 527 U.S. 308, 318-19 (1999). 
original source of the territoriality principles supplies just such a principle: international comity.

\section{a. International Comity as the Animating Principle}

"Comity?!", cried the reader of this long article thus far. For those trained in the U.S. legal tradition, the comity doctrine may be an uninspiring, weak tea of a doctrine. Such reaction usually stems from the doctrine's vagueness and uncertainty. Hilton v. Guyot, the most cited U.S. Supreme Court precedent for comity, gives this ambivalent description of the concept: "comity is, and ever must be, uncertain; that it must necessarily depend on a variety of circumstances which cannot be reduced to any certain rule." $" 326$ Courts and legal academics have waged a sustained series of attacks against this ambiguous character of comity. Judge Benjamin Cardozo said "comity" suggested "a discretion unregulated by general principles." 327 Professor Harold Maier called comity "an amorphous never-never land whose borders are marked by fuzzy lines of politics, courtesy and good faith."328 Professor Paul Stephan similarly said: "Vague terms, such as 'comity' promise much and deliver little in terms of usable instructions for judges facing a potential encounter with foreign courts." 329 Calling for the comity doctrine to be abandoned, Professor Joel Paul gave a litany of different definitions that "comity" has had:

Comity has been defined variously as the basis of international law, a rule of international law, a synonym for private international law, a rule of choice of law, courtesy, politeness, convenience or goodwill between sovereigns, a moral necessity, expediency, reciprocity, or "considerations of high international politics concerned with maintaining amicable and workable relationships between nations." ${ }^{, 330}$

This confused state of the law led to an inconsistent application of the comity doctrine. For example, in a pair of cases decided in 1997, the Peruvian government fell on both sides of the comity doctrine. In Pravin Banker Associates, Ltd. v. Banco Popular del Peru, the Second Circuit found that Peruvian government's request for a moratorium on the payment of certain bank debts (which Peru guaranteed) did not warrant an application of

326. 159 U.S. 113, 164 (1895); see also RESTATEMENT (THIRD) OF THE FOREIGN RELATIONS LAW OF THE U.S. § 403 (AM. LAW INST. 1987) (providing examples of eight factors while calling the court to "evaluat[e] all relevant factors" when considering whether to exercise extraterritorial jurisdiction).

327. Loucks v. Standard Oil Co., 120 N.E. 198, 201-2 (N.Y. Ct. App. 1918) (citing Joseph Beale, CONFLICT OF LAWS $\S 71)$.

328. Harold Maier, Extraterritorial Jurisdiction at Crossroads: The Intersection Between Public and Private International Law, 76 AM. J. INT'L L. 280, 281 (1982).

329. Stephan, supra note 207, at 205.

330. Joel R. Paul, Comity in International Law, 32 HARV. INT’L L.J. 1, 3-4 (1991). 
comity. ${ }^{331}$ Only eight weeks later in Torres v. Southern Peru Copper Co., the Fifth Circuit held that comity required accepting Peru's request that the U.S. litigation be stopped so that the Peruvian government might regulate its own matters, in this case involving industrial pollution. ${ }^{332}$

Given this confusion, criticisms of comity as the current U.S. legal doctrine are well-placed. But the criticisms are off the mark if they are directed to the original conception of comity from the times of the Peace of Westphalia. Ulrich Huber's writing, for example, makes clear that Huberthe source of the territoriality doctrine in Pennoyer - conceived comity as a mandatory obligation. ${ }^{333}$ To Huber, comity was not discretionary, unlike the comity doctrine in U.S. law today. Huber intended comity to be a part of the universal international law, on par with the principles of territorial sovereignty. ${ }^{334}$

Early Supreme Court decisions on territoriality lend support to Huber's more muscular type of comity. In The Schooner "Exchange" v. M'Faddon, the Supreme Court's first pronouncement of the territoriality principle simultaneously held that a sovereign's law is supreme within its territory and the interest of the foreign sovereign must be respected, even if the foreign sovereign's interest is in the form of a warship located within the United States. ${ }^{335}$ Although M'Faddon did not use the word "comity" to support its holding, Justice Story would write just a decade later in The Santissima Trinidad that the M'Faddon decision "stands upon principles of public comity and convenience." ${ }^{336}$ Hilton did much to weaken the application of comity by holding that "comity is, and ever must be, uncertain." 337 Yet the idea that comity is the principle that mediates the clash between sovereigns has survived the damage that Hilton wrought. Comity's staying power is particularly visible in the Full Faith and Credit jurisprudence, which is seen as implementing the rules of comity to regulate the sovereign interests of the

331. 109 F.3d at $850,852-54$ (2d Cir. 1997).

332. 113 F.3d 540, 541 (5th Cir. 1997).

333. See Mills, supra note 65, at 26; ALAN WATSON, JOSEPH STORY AND THE COMITY OF ERRORS: A CASE STUdY IN CONFLiCT OF LAWS 8-9 (1992).

334. Although beyond the scope of this paper, the history of comity doctrine in U.S. law and the process through which Huber's conception of mandatory comity turned into a discretionary one is highly interesting. For a compelling account, see Watson, supra note 333, at 27-44.

335. 11 U.S. (7 Cranch) 116, 136-46 (1812); see also Theodore D. Woolsey, INTRODUCTION TO THE STUDY OF INTERNATIONAL LAW 23 (1895) ("Comity is another duty of nations. . . the term seems to embrace not only that kindness which emanates from friendly feeling, but also tokens of respect which are $d u e$ between nations on the ground of right.").

336. 20 U.S. (7 Wheat.) 283, 353 (1822).

337. 159 U.S. at 164. 
various states. ${ }^{338}$ The principle of comity also remains alive in the international context, as many of the landmark Supreme Court cases reining in the lower court's assertions of extraterritorial jurisdiction beyond U.S. borders have cited comity as the basis for giving respect to foreign sovereigns. $^{339}$ What is more, even in the cases that allowed the U.S. court to venture beyond the national borders, the Supreme Court usually felt the need to give some considerations for the principle of international comity. ${ }^{340}$

Comity has much to offer if we consider it a higher-order principle that is on par with the principle of sovereign territoriality. Ulrich Huber, whose territoriality principles form the basis of the U.S. territoriality doctrine, considered comity to be obligatory. Although it is true that the current U.S. doctrine on comity is vague and uncertain, comity may be re-imagined as the governing principle that animates the legal test that resolves the competing interests of various sovereigns in the context of Equity Extraterritoriality.

\section{b. Proposed Approach: Comity-Fueled Conflict of Laws Test}

My reliance on Huber's theory of comity is not to say that Huber had worked out all the details on how the comity principle would operate as a legal test - after all, Huber's principles were closer to being political theories rather than a workable legal doctrine. ${ }^{341}$ What would the comity-fueled legal

338. See, e.g., JOSEPH STORY, COMMENTARIES ON THE CONSTITUTION OF THE UNITED STATES $\S$ 1309 (1833) (The Full Faith and Credit Clause "import[s] no more than that the same faith and credit are to be given to [state court judgments], which, by comity of nations, is ordinarily conceded to all foreign judgments[.]"); Franchise Tax Bd. v. Hyatt, 538 U.S. 488, 492-93 (2003) (discussing the implication of comity within the context of Full Faith and Credit Clause). See also Kelly Stoner and Richard A. Orona, Full Faith and Credit, Comity, or Federal Mandate? A Path that Leads to Recognition and Enforcement of Tribal Court Orders, Tribal Protection Orders, and Tribal Child Custody Orders, 34 N.M. L. REV. 381, 382 (2004) (discussing interaction between Full Faith and Credit Clause and the comity doctrine with respect to recognition of Native American tribal court orders).

339. See, e.g., Am. Banana Co. v. United Fruit Co., 213 U.S. 347, 356 (1909) ("For another jurisdiction ... to treat him according to its own notions rather than those of the place where he did the acts ... would be an interference with the authority of another sovereign, contrary to the comity of nations . . .."); Kiobel v. Royal Dutch Petroleum Co., 569 U.S. 108, 128 (2013) (Kennedy, J. concurring) ("Adjudicating any such claim must ... also be consistent with those notions of comity that lead each nation to respect the sovereign rights of other nations ...."); Daimler AG v. Bauman, 134 S. Ct. 746, 763 (2015) ("The Ninth Circuit, moreover paid little heed to the risks to international comity its expansive view of general jurisdiction posed."). See also Breyer, supra note 21, at 92 ("In applying [comity], our Court has increasingly sought interpretations of domestic law that would allow it to work in harmony with related foreign laws, so that together they can more effectively achieve common objectives.").

340. See, e.g., Societe Nationale Industrielle Aerospatiale v. U.S. D. for the S.D. Cal., 482 U.S. 522, 537 n. 23 (1987) ("Both comity and concern for the separation of powers counsel the utmost restraint in attributing motives to sovereign states which have bargained as equals."); Hartford Fire Ins. Co. v. Cal., 509 U.S. 764, 770 (1993) ("[T]he principle of international comity does not preclude District Court jurisdiction over the foreign conduct alleged.").

341. See Hazard, supra note 66, at 260. To the extent that Huber developed a legal test based on 
test that governs Equity Extraterritoriality look like? I submit that it would look fairly similar, but not identical, to conflict of laws. ${ }^{342}$ Comity's chief concern is to harmonize the competing interests of the sovereigns. Brainerd Currie noted that conflict of laws jurisprudence has the same concern: "The central problem of conflict of laws may be defined, then, as that of determining the appropriate rule of decision when the interests of two or more states are in conflict - in other words, of determining which interest shall yield."343 Professor Donald Childress noticed this parallel between comity and conflict of laws, and argued that international comity may be resituated as conflict of laws. ${ }^{344}$ I broadly agree with Childress's observation, and believe that conflict of laws jurisprudence may inform the way in which Equity Extraterritoriality may be restrained.

However, a caveat is necessary: Equity Extraterritoriality is not entirely a question of conflict of laws, whose operation usually involves choosing the law to be applied to determine a given controversy. ${ }^{345}$ Despite Currie's observation that the chief concern of conflict of laws is the mediation of competing sovereign interests, the conflict of laws test that actually operates within the U.S. jurisprudence usually involves mediation of competing laws, which is not entirely synonymous with mediation of the competing sovereign interests. $^{346}$ "Foreign sovereign interest" is a higher-order concept than "foreign law"; a foreign sovereign's interest covers a greater range than what is expressed in its laws. Thus, the test to regulate Equity Extraterritoriality may be characterized as "conflict of sovereign interests" test, analogous to

comity, such a test was for situations in which courts of one country had to apply the laws of another country, and not necessarily for balancing sovereign interests. See generally Paul, supra note 330, at 1517.

342. See William S. Dodge, International Comity in American Law, 115 COLUM. L. REV. 2071, 2079 (2015) (classifying conflict of laws as one of the expressions of the comity principle).

343. Brainerd Currie, Selected Essays on Conflicts of LAWs 178 (1963). See also FRIEDRICH K. JUENGER, SELECTED ESSAYS ON THE CONFLICT OF LAWS 168 (2001) ("Interest analysis is, after all, an attempt to derive solution to conflicts problems from the notion of sovereignty."); Dodge, supra note 342, at 2073 ("Comity has long served as the basis for the conflict of laws ....").

344. See Donald E. Childress III, Comity as Conflict: Resituating International Comity as Conflict of Laws, 44 U.C. DAVIS L. REV. 11, 62-78 (2010).

345. See Welkowitz, supra note 23, at 17.

346. See, e.g., Hartford Fire Ins. Co. v. Cal., 509 U.S. 764, 798 (1993) ("The only substantial question in this litigation is whether there is in fact a true conflict between domestic and foreign law.") (internal quotation omitted); In re Vitamin C Antitrust Litig., 2016 U.S. App. LEXIS 17135, at *23 ("To determine... whether a 'true conflict' exists, we must determine conclusively what the law of each country requires.") (emphasis added). See also Welkowitz, supra note 23, at 17 (noting that the problem of extraterritorial injunctions is not reducible to conflict of laws, because " $[\mathrm{t}]$ he problem is not with the application of the forum law to the problem in the first instance, but rather with granting an extraterritorial remedy"). 
conflict of laws in structure but with the greater range of concern motivated by comity. ${ }^{347}$ This is because the problem of Equity Extraterritoriality is not merely an interference with a foreign law, but an interference with a foreign sovereign interest. In other words, the test may be described as "comityfueled conflict of laws."

Considering the points discussed above, I propose the following legal test to restrain the excess of international Equity Extraterritoriality. I propose that Equity Extraterritoriality analysis should resolve the competing sovereign interests by way of shifting presumptions. So far, to the extent that the courts have analyzed Equity Extraterritoriality at all, they did so based on some type of balancing test. The Supreme Court in Aerospatiale, for example, explicitly refused to provide any guidance as to how lower courts might issue an extraterritorial discovery order. ${ }^{348}$ The lower courts, grasping for straws, formulated a number of different balancing tests that evaluated anywhere between three and seven factors. ${ }^{349}$ These balancing tests mostly failed to give proper respect to the interests of foreign sovereigns, resulting in a dramatic increase in the number of extraterritorial discovery orders that explicitly mandated the party to break a foreign law. ${ }^{350}$ This was to be expected; indeed, the dissenting opinion in Aerospatiale predicted this exact result, noting "courts are generally ill equipped to assume the role of balancing the interests of foreign nations with that of our own." 351

347. See, e.g., Bigio v. Coca-Cola Co., 448 F.3d 176, 178 (2d Cir. 2006) (holding that conflict of laws test is the incorrect standard for applying international comity, because "the only issue of international comity . . . is whether adjudication of this case by a United States court would [sic] amicable working relationships" with a foreign state) (internal quotation omitted); Freund v. Republic of France, 592 F. Supp. 2d 540, 574 (S.D.N.Y. 2008) (finding that Hartford Fire-style conflict analysis "is most often applied when comity principles intersect with issues of statutory construction[,]" and comity considerations operate beyond the "true conflict" analysis).

348. Societe Nationale Industrielle Aerospatiale v. U.S. D. for S.D. Cal., 482 U.S. 522, 546 (1987) ("We do not articulate specific rules to guide this delicate task of adjudication."); see also Timberlane Lumber Co. v. Bank of Am., 549 F.2d 597, 614 (9th Cir. 1976) (proposing a seven-factor balancing test for applying U.S. antitrust law extraterritorially).

349. See Sant, supra note 23, at 187.

350. See id. at 225-32. For criticisms of balancing tests applying territoriality principles, see Breyer, supra note 21, at 100 ("[T] he [Timberlane balancing] test is complex, opening the door to broad judicial discretion, and thus it creates unpredictability."); Larry Kramer, Extraterritorial Application of American Law After the Insurance Antitrust Case: A Reply to Professors Lowenfeld and Trimble, 89 AM. J. INT'L L. 750, 754 (1995) ("Case-by-case balancing is a bad idea ... . The considerations being weighed are always imprecise enough to permit several answers and to dictate none.”); Meyer, supra note 222, at 160 ("[W]hen this balancing analysis is foisted upon judges, it undermines the appropriate role of courts as neutral interpreters of the law.").

351. Aerospatiale, 482 U.S. at 552 (Blackmun, J., dissenting). 
If we are to stay true to Huber's principle that comity is obligatory, a more forceful approach is necessary. My proposal is a legal test of shifting presumptions, which is often employed when vital interests such as civil rights are at stake. ${ }^{352}$ The baseline presumption should remain the same as it is today: the court may exercise its authority over persons under its jurisdiction, including the authority to issue extraterritorial orders. ${ }^{353}$ This is consistent with the territoriality principle that a sovereign may govern the affairs occurring within its own territory. ${ }^{354}$ But the burden of proof would shift if the person who would be so ordered makes a prima facie case that the court's exercise of Equity Extraterritoriality unduly contravenes an important interest of a foreign sovereign. The party seeking the extraterritorial order must then establish that the order does not unduly contravene an important foreign sovereign interest.

The final result of this test would turn on two factors, which are to be considered on a staggered scale: (1) the type and quality of foreign sovereign interest involved, and; (2) the type and quality of the clash in sovereign interests that the extraterritorial order would cause if granted.

The first factor would consider the type of foreign sovereign interest involved on a cascading scale of importance. Topping the scale as the most important would be when the foreign sovereign's interest is implicated directly, ${ }^{355}$ such as when the extraterritorial order directly binds the sovereign $^{356}$ or directly affects sovereign assets. ${ }^{357}$ Under such circumstances, only a clear and unequivocal mandate from the political branches would allow the court to rely on Equity Extraterritoriality to infringe upon these interests. Next on the scale is the regulatory interest of the foreign state that is expressed as a specific piece of law. ${ }^{358}$ Lower on the

352. See, e.g., McDonnell Douglas Corp. v. Green, 411 U.S. 792, 802-03 (1973) (announcing a test of shifting presumption in applying Title VII of the Civil Rights Act of 1964).

353. See CURRIE, supra note 343, at 183 ("Normally, even in cases involving foreign elements, the court should be expected, as a matter of course, to apply the rule of decision found in the law of the forum.").

354. See discussion supra Section III.A.

355. See Dodge, supra note 342, at 2099 (noting that one of the types of comity is "sovereign party comity," i.e. deference to foreign governments as litigants).

356. See, e.g., Agudas Chasidei Chabad of United States v. Russian Fed'n, 915 F. Supp. 2d 148, 154-55 (D. D.C. 2013); FG Hemisphere Assocs. v. Dem. Republic of Congo, 637 F.3d 373, 380 (D.C. Cir. 2011); BAE Sys. Tech. Solution \& Servs. v. Republic of Korea's Def. Acquisition Program Admin., 195 F. Supp. 3d 776, 801-03 (D. Md. 2016).

357. See Republic of Argentina v. NML Capital, 134 S. Ct. 2250, 2258 (2014).

358. See DAVID F. CAVERS, The CHOICE-OF-LAW Process 100 (1965) (It is "reasonable to ascribe to the state a desire to have the purposes its laws effectuated in situations where this would appear to advance those purposes"). An intermediate position between the direct sovereign interest and regulatory sovereign interest may be the sovereign interest in a state-owned enterprise, doing business in the 
scale is the position of the foreign sovereign on a discrete issue that is not necessarily expressed as written law, but expressed clearly to the U.S. judiciary through diplomatic communications or amicus curie briefs. Even lower on the scale is any remaining interest of foreign sovereigns that is not formally expressed but otherwise discernible, such as recent trends in the laws of the foreign states or a statement from a high-ranking foreign government official in charge of the relevant area. As the importance of the foreign sovereign interest implicated rises, so too must be the burden that the party applying for the extraterritorial order to satisfy. When the foreign sovereign interest is in the first category, a petition for Equity Extraterritoriality order should almost always be denied; when the foreign sovereign interest is in the last category, such a petition should almost always be granted.

The second factor would consider the type and quality of the clash between the interests of the U.S. sovereign and the foreign sovereign. The scale for assessing the quality of the clash corresponds to the scale of weighing foreign sovereign interests discussed above. The most significant level of clash between the two sovereigns is when a U.S. court is called to directly challenge the interest of the foreign sovereign itself; accordingly, the presumption against an Equity Extraterritoriality order in such a situation should be the most difficult to overcome. The next significant level is when an extraterritorial order commands an action that is prohibited by the foreign sovereign by law or regulation, such that the party to be ordered by the court would end up violating the foreign law or regulation as a result of complying with the U.S. court order. Next on the scale is when the Equity Extraterritoriality order does not necessarily violate a foreign law, but puts the party to be ordered under competing legal obligations, such as a preexisting contractual duty owed to a foreign third party, such that the order creates double liability. Lowest on the scale would be when the U.S. court order commands an action that is neither explicitly prohibited by the foreign sovereign nor causing conflicting legal obligations, but contravenes the general public policy aims of the foreign sovereign. The same calculus would apply to this factor: when the clash of sovereign interests is in the first category, petition for an Equity Extraterritoriality order should almost always be denied; when the clash is in the last category, such a petition should almost always be granted.

Below, I further propose several general principles that would govern the operation of this test.

marketplace in a way indistinguishable from private actors. See, e.g., 28 U.S.C. § 1610(a) (2012) (allowing execution against sovereign property used for commercial activity). 
First, the analysis for Equity Extraterritoriality outlined above must be available at any point during the litigation, at any time when the court considers issuing an order that may have an extraterritorial effect. This is because a situation involving Equity Extraterritoriality may arise at any point during the litigation-for example, in a temporary restraining order, prejudgment attachment, discovery, or post-judgment asset discovery. ${ }^{359}$ Because comity is an obligation, it must be ready to come into play at any time there is a potential clash of sovereign interests. This has the same logic that drove the Supreme Court's recent decision in Sinochem, in which the court found that forum non conveniens doctrine is available at any time during the litigation, even before the court established personal and subject matter jurisdiction. ${ }^{360}$ Forum non conveniens is another mechanism to mediate the potential clash of sovereign interests, in that it is invoked when there is an alternate forum outside of the United States, presumably with its own interest in adjudicating the dispute. ${ }^{361}$ It would be sensible that our proposed mechanism to harmonize the competing interests of sovereigns operates in the same way by making itself available throughout litigation.

Second, the coverage of extraterritorial orders cannot reach beyond the person whose personal jurisdiction the court already established. This is to stop the courts from bootstrapping their way into reaching every corner of the world by way of an extraterritorial order, by claiming that assisting the violation of its orders causes an effect within the United States. ${ }^{362}$ On the jurisdictional extraterritoriality side, it is a settled rule that the court cannot assert specific jurisdiction over an out-of-state defendant whose only contact with the forum is through the plaintiff. ${ }^{363}$ A similar rule must hold for Equity Extraterritoriality: the court cannot assert jurisdiction over a foreign person whose only contact with the forum is through the court's extraterritorial order. To ensure compliance with its Equity Extraterritoriality order, the court may order the person who is already under the court's jurisdiction. To

359. Somewhat alarmingly, an Equity Extraterritoriality situation regularly arises in the "jurisdictional discovery," under which the U.S. courts order discovery over a foreign party to find evidence that may establish personal jurisdiction. See generally S.I. Strong, Jurisdictional Discovery in the United States Federal Courts, 67 WASH \& LEE L. REV. 489, 492 (2010). Such discovery, by definition, occurs before the court establishes personal jurisdiction, and almost always involves discovery of evidence located beyond the court's territorial jurisdiction, as it is conducted over a foreign party.

360. Sinochem Int'1 Co. v. Malay. Int'1 Shipping Corp., 549 U.S. 422, 425 (2007).

361. See id. at 430 .

362. See discussion supra at Section IV.C.3.

363. See World-Wide Volkswagen, 444 U.S. 286, 291 (1980); McIntyre Mach. v. Nicastro, 564 U.S. 873, 885-90 (2011). 
reach third parties, the court must first establish an independent basis for jurisdiction over them.

Third, even in situations that warrant the issuance of an extraterritorial order, the court must modulate the reach of its order by taking into account the strength of the two links of control that make up Equity Extraterritoriality: the court's control over a person, and the person's control over properties or conduct subject to the court's order. If personal jurisdiction was established by a relatively weak basis, such as "tag" jurisdiction, the court must be particularly circumspect in issuing a farreaching extraterritorial order. Similarly, if the person to be ordered is a third party to the litigation whose control over the properties is constructive rather than actual - such as the intermediary banks that are "holding" the funds during an electronic fund transfer-the court must consider the extraterritorial effects of its order even more carefully than usual.

Fourth, in weighing the sovereign interests, the court must actively solicit the views of the foreign governments and the U.S. political branches, and give due deference to those views. ${ }^{364}$ This is to address the current situation in which "U.S. courts will often unilaterally decide that the foreign states' interests are something different from what the foreign states assert." 365 Direct expression of the sovereign interest is necessary because submissions by private parties are inadequate to accurately assess the views of the foreign sovereign. To be sure, foreign sovereigns need not weigh in on every instance of Equity Extraterritoriality; their silence could also be an indication of the level of their interest. The involvement of the U.S. political branches - which would be primarily the U.S. Department of State - is also important, as mediating the competing sovereign interests is "a political function of a very high order" 366 that merits an input from the political branches that reflect the nation's democratic will.

Fifth, in making the determination, the court must leave a clear statement of the manner in which it applied the various factors such as the identified interest of the foreign sovereign, the importance of the said interest, the level of challenge that its extraterritorial order would pose to the said interest, views of the foreign sovereign and the United States, and so on.

364. See United States v. Pink, 315 U.S. 203, 218-20 (1942) (treating the Russian government's interpretation regarding a Russian decree as “conclusive"); In re Vitamin C Antitrust Litig., 837 F.3d 175, 186-89 (deferring to the declaration by the Chinese government's interpretation of Chinese law regarding price controls). See also Childress, supra note 344, at 53-59 (discussing statements submitted by the governments of South Africa and the United States in In re S. African Apartheid Litig., 617 F. Supp. 2d 228, 276 (S.D.N.Y. 2009)).

365. Sant, supra note 23, at 222.

366. Currie, supra note 353, at 182. 
This may seem to be too obvious of a point in a common law system like the U.S. law, which depends on the courts' opinions to build the body of the law. Yet the lack of the courts' attention on Equity Extraterritoriality has precisely been the problem, leading to the doctrine's underdevelopment. Particularly when they are called to give shape to principles of international law such as comity, courts have been engaged in "a practice of compounded avoidanceavoiding," 367 refusing to give a more definite construction of international law principles as applied to the U.S. law. The problem of Equity Extraterritoriality, in large part, is a problem of neglect. To redress this problem, the courts must make a concerted effort to develop a rigorous test that could respond to the many different situations under which Equity Extraterritoriality concerns may arise.

\section{c. Application of the Proposed Test}

The effect of this proposed test is admittedly far-reaching, because the proposal completely reverses the treatment of Equity Extraterritoriality in the U.S. law. But the cases at the top and the bottom of the scale will remain the same. At the top of the scale, for example, the U.S. court may issue an extraterritorial order to enforce an embargo, authorized by the political branches, against a state sponsor of terrorism. Although the interest of the foreign sovereign may be directly implicated in such a situation, the U.S. sovereign clearly made known its intention to override the foreign sovereign interest. As an apparatus of the U.S. sovereign, the U.S. court must be able to implement its own sovereign interest in such a situation. At the bottom of the scale, for example, the U.S. court may issue an Equity Extraterritoriality order to command a defendant to return a specific piece of physical, personal property that he illegitimately took out of the court's territorial jurisdiction. Unlike intangible property, physical property is unlikely to invite the foreign sovereign's regulatory interest - especially if the physical property was not present in the foreign sovereign's territory in the first place. Physical property is also less likely to be subject to multiple competing claims of ownership and encumbrance, creating less risk of conflicting legal obligations.

The intermediate cases, however, would have a different result from the current regime. Both of the Argentina bond cases - one involving the order prohibiting payment, ${ }^{368}$ and the other involving sovereign asset discovery $^{369}$ — would have a different outcome, because they directly bind

367. Swaine, supra note 22, at 716 .

368. See NML Capital, 699 F.3d 246, 254 (2012).

369. See NML Capital, 134 S.Ct. 2250, 2258 (2014). 
the foreign sovereign or the assets owned by the foreign sovereign. In those cases, the U.S. courts would be prohibited from issuing an extraterritorial Equity order. Cases that are next on the scale, which may cause a person to violate foreign law, would likely have a different result as well. An example of a case on level is Fargo $v$. Redfield, ${ }^{370}$ in which the federal district court in Vermont enjoined a Canadian corporation from adjusting the rail fare on the tracks that went from Vermont to Canada, although a Canadian law mandated the fare adjustment. Under my proposed test, this would not be permissible: the Canadian sovereign expressed its interest by passing a law, which the Canadian rail company would be forced to violate if the company followed the U.S. court's Equity Extraterritoriality order. There is no U.S. sovereign interest in this case, other than the diffuse and generalized interest in overseeing the contracts made by a U.S. party. In such a case, the U.S. court must respect the clearly expressed interest of a foreign sovereign, and refrain from issuing the requested order. ${ }^{371}$

A close case would be a situation like Koehler, in which a New York court ordered a Bermudan bank (that submitted to the court's jurisdiction) to deliver stock certificates in order to satisfy the debt owed by the judgment debtor who kept the certificates at the bank. ${ }^{372}$ Under the proposed test, it is likely that the result in Koehler will remain the same. There is no indication that the stock certificates are subject to competing claims of ownership in Bermuda, and there is no other discernible interest expressed by the sovereign of Bermuda. Although the bank is a third party, the court's claim of jurisdiction over the Bermudan bank is strong, and so is the bank's control over the stock certificates. But small tweaks in the facts may change the outcome. For example, if the stock certificates were serving as collateral for a loan, and the judgment debtor's loss of control in the stock certificates would trigger a default such that the (foreign) guarantor of the loan would have to immediately repay the loan, the U.S. court would have to give due consideration to this extraterritorial effect of its turnover order. (In my view, this is probably the closest case in which Equity Extraterritoriality order may be justified.) Similarly, cases involving extraterritorial discovery would be a close, fact-intensive call. The outcome would depend on several factors, such as the presence of foreign blocking statutes or other expressions of foreign sovereign interest, the nature of the evidence to be discovered

370. 22 F. 373, 375 (C.C.D. Vt. 1884).

371. This is similar to the current doctrine of international comity abstention. See, e.g., Royal \& Sun All. Ins. Co. of Can. v. Century Int'l Arms, Inc., 466 F.3d 88, 92 (2d Cir. 2006); In re Vitamin C Antitrust Litig., 837 F.3d 175, 183 (2d Cir. 2016).

372. Koehler v. Bank of Bermuda, 12 N.Y.3d 533, 536 (2009). 
(tangible or intangible, for example,) and the quality of control that the party to be ordered has over the evidence to be discovered, and so on.

B. Potential Objections to the Proposed Test

My proposed test will certainly invite objections, because it represents a sea change in the U.S. law's territoriality and comity doctrines. This approach requires that Equity Extraterritoriality be considered extraterritorial, although the current U.S. legal thought mostly equates extraterritoriality with jurisdictional extraterritoriality. ${ }^{373}$ It also requires comity and deference to foreign sovereigns as an obligation, not discretion. ${ }^{374}$ It may be argued that this approach takes away from the courts the flexibility traditionally accorded to equitable remedies, potentially turning the courts into "a mere errand boy for the Executive Branch which may choose to pick some people's chestnuts from the fire, and not others," as the Supreme Court put it in a case involving Equity Extraterritoriality. ${ }^{375}$ To these objections, I submit respectfully: as far as Equity Extraterritoriality is concerned, those results are exactly what this approach seeks to achieve. As it stands today, Equity Extraterritoriality has no real legal boundaries. Only the court's variable sense of modesty stops it from ordering parties to break foreign laws, putting parties under double liability, or compelling foreign sovereigns to disclose its military assets. A squishy concept like the current U.S. doctrine of discretionary comity is not up to the task of putting a more meaningful check on these extraterritorial excursions. If the U.S. law is to give any meaning to the doctrine of sovereign territoriality-the foundational principle of modern international world order-it must also accept as foundational the principle that manages the conflict among the interests of various sovereigns. Assessing competing sovereign interests is a highly political act, more properly left to the political branches that are empowered with the authority to conduct foreign policy under the Constitution. The necessary conclusion, then, is any legal test that seeks to restrain the excess of Equity Extraterritoriality cannot avoid being in some way rigid, and in some way deferential to the Executive, Congress, and foreign sovereigns. ${ }^{376}$

373. See discussion supra at Section II.B.

374. See discussion supra at Section V.A.2.a.

375. First Nat'l Bank v. Banco Nacional de Cuba, 406 U.S. 759, 773 (1972) (Douglas, J., concurring).

376. See Dodge, supra note 355, at 2071 (noting that only in the case of "adjudicative comity" does the comity operate more as a general standard rather than a specific and rigid rule). 
However, there is a stronger, more fundamental objection. The problem of Equity Extraterritoriality is ultimately the problem of applying the territoriality principle. But what if you do not care about territoriality? Perhaps no solution is necessary for Equity Extraterritoriality, because extraterritoriality is not a problem.

There are solid arguments in favor of being more permissive on extraterritoriality. Chief among them is a sense of national competition-"if we don't have it our way, they will have it their way." "377 The U.S. judiciary is certainly not the only one reaching beyond its nation's territorial boundaries, as a number of countries including Germany, Japan, Canada and United Kingdom have also adopted some version of the "effects" test to regulate matters occurring outside of their territory. ${ }^{378}$ In doing so, the courts of these countries - just as much as the U.S. courts - do little to restrain themselves. ${ }^{379}$ One may also argue that not all sovereigns are created equal, such that not all sovereign interests are equal. The United States' commitment to liberal democracy may mean that the U.S. courts must not give any deference to foreign sovereign interests that are not an expression of the democratic will (such as the interest of the North Korean sovereign) or those that contravene the established liberal principles (such as foreign laws compelling racial discrimination.) ${ }^{380}$ Practicality of regulations is yet another reason to soften the stance on territoriality. It may be argued that if the United States wants to regulate actions occurring beyond its borders that significantly affect it, it can only do so through its courts because a sovereign nation has no true political recourse to control the non-resident individual's actions that occur outside of the country. ${ }^{381}$ Failure to regulate extraterritorially undermines the domestic regulatory scheme, because companies doing business in the United States may be able to opt out of the

377. See Burbank, supra note 159 , at 1342.

378. See RAUSTIALA, supra note 2, at 125; see also Handl, supra note 194, at 4 ("[T]erritorial sovereignty could never convincingly be posited as an absolute principle. Instead, it was understood to require some adjustment in view of states' physical co-existence and associated transboundary spill-over effects, and the desirability of international trade and diplomatic intercourse.").

379. See Swaine, supra note 22, at 687-88; see also Paul, supra note 330, at 7 ("deference to foreign sovereigns in the name of comity is neither required by customary international law nor reciprocated in practice.").

380. See Louis Henkin, International Law: Politics And Values 9 (1995) ("Sovereignty, a conception deriving from relations between a prince and his/her subjects, is not a necessary or appropriate external attribute for the abstraction we call a state."); W. Michael Reisman, Sovereignty and Human Rights in Contemporary International Law, 84 AM. J. INT'L L. 866, 876 (1990) (“Those who . . continue to trumpet terms like 'sovereignty' without relating them to the human rights conditions within the states under discussion do more than commit an anachronism. They undermine human rights.”).

381. See Welkowitz, supra note 23, at 52-53. 
stricter regulatory regime. ${ }^{382}$ This problem is particularly acute in the context of Equity Extraterritoriality, which often involves parties already under the court's jurisdiction. Giving additional considerations for actions occurring beyond the U.S. borders, in essence, creates a two-track system within the court that favors the party engaging in actions abroad. Indeed, this was one of the key reasons why the Supreme Court in Aerospatiale upheld the Equity Extraterritoriality in the context of discovery, even at the cost of ignoring the Hague Evidence Convention. ${ }^{383}$

What about the conflicts with other sovereigns that the "spillover" of regulations may cause? It may be argued that more often than not, the effect of the spillover is a net positive. Actions occurring across national borders tend to be under-enforced at any rate. It is preferable to have the regulation spill over beyond the national territory than to suffer the harms arising from no regulation at all. ${ }^{384}$ Further, such spillover, and the resulting (temporary) diplomatic strife, may ultimately lead to the harmonization of the international regulatory scheme. The initial extraterritorial excursion could function like "an initial bid in a kind of contractual bargaining between the United States and the rest of the world." 385 The courts of the various nations could behave like arms-length parties negotiating toward an agreement, and their respective claims of extraterritorial authority would serve as the device for such negotiation. ${ }^{386}$

For the practical-minded, these arguments can be quite attractive. Equity Extraterritoriality is often the best friend of a U.S.-based attorney representing a client who is harmed by a foreign party's conducts occurring abroad. Ultimately, however, I fall on the side of respecting tradition and enhancing predictability of the law. ${ }^{387}$ There is a good reason why our courts have adhered to the territoriality principle since the beginning of the Republic, despite the periods of waxing and waning doctrinal strength. Because the concept of territorial sovereignty rests at the heart of the international order, the logical conclusion of ignoring the territoriality principles is the undoing the Westphalian order. I do not intend to be overly

382. See Paul, supra note 330 , at $73-74$.

383. See Aerospatiale, 482 U.S. at 561-67; see also Bermann, supra note 163, at 543-46 (criticizing the court's reasoning in Aerospatiale).

384. See Goldsmith, supra note 48, at 490 (arguing in favor of regulatory spillover in the internet context).

385. Stephan, supra note 207, at 92.

386. For contract-negotiation theory of international judicial cooperation, see Stephan, supra note 207. For a theory of global regulatory harmonization through spillover effects, see Bradford, supra note 208.

387. See Oliver Wendell Holmes, The Path of the Law, 10 HARV. L. REV. 457, 458 (1897). 
dramatic, as the Peace of Westphalia would surely survive some modifications around the edges. Nor is it the case that I oppose all extraterritorial application of U.S. laws - my proposed solution makes clear that even under more rigorous application of territoriality principles, U.S. courts may still make extraterritorial orders. What I do find concerning, however, is that a single district court may cause a far-reaching international event, such as cutting off a sovereign nation from the international capital market. $^{388}$ Modifications to the Westphalian order, and extraterritorial application of national laws, must come through the political branches reflecting the democratic will, because assessing the interest of the various sovereigns is a "political function of a very high order."389 Yet the current state of the Equity Extraterritoriality doctrine allows the Court to ignore the decisions of the political branches, as the Supreme Court did in Aerospatiale by making the Hague Evidence Convention - a bargained-for multilateral treaty that the U.S. executive signed - all but a dead letter. ${ }^{390}$ To the extent the courts have to reach beyond their territorial jurisdiction, it must do so in a cautious manner that gives a proper nod to the political branches of the United States, as to the interests of other sovereigns. The current Equity Extraterritoriality doctrine, whose contours are poorly defined, is not up to this task.

\section{CONCLUSION}

Equity Extraterritoriality is all instances of the court issuing an extraterritorial order, which originates from the court's equity tradition. Considering its practical significance, the neglect of Equity Extraterritoriality is surprising. The doctrine has a long history dating back to pre-American Independence English law. Supreme Court approved Equity Extraterritoriality in Pennoyer, despite the fact that Equity Extraterritoriality contradicted the territoriality principles that Pennoyer applied on judicial jurisdiction. The merger of law and equity and the personal jurisdiction revolution in the mid-20th century removed the last remaining checks on the reach of Equity Extraterritoriality, by allowing the courts to exercise jurisdiction far beyond their territorial jurisdiction in situations that the courts sitting in equity previously could not reach. Although the jurisprudence on personal jurisdiction retrenched in the late 20 th century and early 21 st century, such retrenchment only served to widen the gap between jurisdictional territoriality, which cautions against

388. See Cross supra at note 124; Pomager supra note 124.

389. Currie, supra note 343 , at 182.

390. See Bermann, supra note 163. 
extraterritorial assertion of judicial power, and Equity Extraterritoriality, which is indifferent to the problems of extraterritoriality.

The heart of the problem with Equity Extraterritoriality is the problem of extraterritoriality, as Equity Extraterritoriality truly is an exercise of U.S. court's authority beyond its territorial jurisdiction, notwithstanding the current U.S. territoriality jurisprudence to the contrary. The developing trends of modern capitalism, in particular its ever-increasing reliance on intangible property, indicate that Equity Extraterritoriality will become even more important in the coming decades, as the interests of multiple sovereigns will cross paths more frequently. But the under-developed state of the doctrine, including its inconsistency with the presumption against extraterritoriality and transnationality blindness, makes it ill-equipped to bear this weight.

To deal with Equity Extraterritoriality is to deal with the problem of extraterritoriality, which in turn is the problem of competing sovereign interests. There are two contexts in which this problem may arise: interstate/domestic and international. To harmonize the competing sovereign interests involved in a case of domestic Equity Extraterritoriality, courts may look to the established principles of the U.S. Constitution, including federalism, separation of powers, the Commerce Clause, the Full Faith and Credit Clause, and the Tenth Amendment. Addressing the problem of international Equity Extraterritoriality requires a more novel approach, because a legal superstructure like the U.S. Constitution does not exist in the international context. International comity as a mandatory principle, on par in terms of strength as the principles of territorial sovereignty, may serve as an animating principle for a conflict of laws-like legal test that would rein in the excess of Equity Extraterritoriality. 